University of Louisville

ThinkIR: The University of Louisville's Institutional Repository

Electronic Theses and Dissertations

\title{
$5-2011$
}

\section{The dialectic of trauma in Charlotte Salomon's Life? or theatre?}

Brooke Leeton

University of Louisville

Follow this and additional works at: https://ir.library.louisville.edu/etd

\section{Recommended Citation}

Leeton, Brooke, "The dialectic of trauma in Charlotte Salomon's Life? or theatre?" (2011). Electronic Theses and Dissertations. Paper 809.

https://doi.org/10.18297/etd/809

This Master's Thesis is brought to you for free and open access by ThinkIR: The University of Louisville's Institutional Repository. It has been accepted for inclusion in Electronic Theses and Dissertations by an authorized administrator of ThinkIR: The University of Louisville's Institutional Repository. This title appears here courtesy of the author, who has retained all other copyrights. For more information, please contact thinkir@louisville.edu. 


\title{
THE DIALECTIC OF TRAUMA IN
}

CHARLOTTE SALOMON'S LIFE? OR THEATRE?

\section{By}

Brooke Leeton

B.S., University of Tennessee, 2002

\author{
A Thesis \\ Submitted to the Faculty of the \\ College of Arts and Sciences of the University of Louisville \\ in Partial Fulfillment of the Requirements \\ for the Degree of
}

Master of Arts

Department of Fine Arts

University of Louisville

Louisville, KY

May 2011 

THE DIALECTIC OF TRAUMA IN

CHARLOTTE SALOMON'S LIFE? OR THEATRE?

By

Brooke Leeton

B.S., University of Tennessee, 2002

A Thesis Approved on

April 18, 2011

by the following Thesis Committee:

Dr. Susan Jarosi, Advisor

Dr. Ann T. Allen

Dr. Jongwoo Jeremy Kim 


\section{DEDICATION}

This thesis is dedicated to my mother, Cathy Summers, and to my grandmother, Lillie Mae Hinch. 


\section{ACKNOWLEDGEMENTS}

I would like to thank my thesis advisor, Dr. Susan Jarosi, for her guidance and patience throughout this process. Her advice, support, encouragement, and wicked editing skills have been invaluable. I want to thank Dr. Jongwoo Jeremy Kim and Dr. Ann Allen for reading my thesis and taking part in my defense. I would also like to thank Dr. Wendy Koenig, and Libby Rowe for inspiring me years ago to make this dream come true. Thanks to Amy Fordham for understanding my predicament and allowing me a flexible work schedule this past year.

I would like to thank my family for their continual support of my educational endeavors. Finally, a few friends deserve special thanks for years of unwavering love and support: Kara Adams, Ashley Baes, Bo Crew, Amber Dixon, Ashley Kuzma, Mandy Linthicum, Jennifer Pina, Misty Ragland, and Brittany Sircy. I could not have made it through this program without Sarah Cassidy and Kaelin Jewell. None of those listed above doubted for a second that I was capable of seeing this through, some day, some how. I am a lucky girl. 


\section{ABSTRACT \\ THE DIALECTIC OF TRAUMA IN \\ CHARLOTTE SALOMON'S LIFE? OR THEATRE? \\ BROOKE LEETON}

APRIL 18, 2011

This thesis explores the presence of the dialectic of trauma in Charlotte Salomon's magnum opus, Life? or Theatre?, a series of more than seven hundred paintings created during her time in exile in France between 1941 and 1942. In this series, modeled on an illustrated operatic libretto, Salomon combined painted images, narrative commentary, dialogue, and musical notation to create a thinly disguised cast of characters representing herself, family members, and friends - who reenact traumatic events that occurred prior to and throughout Salomon's life. This visual manifestation of trauma raises questions about the formation and function of traumatic memory, and how those who experience trauma manage these memories. This thesis examines three critical essays on Salomon's series; art historians Leah White, Ernst van Alphen, and Griselda Pollock each posit that Life? or Theatre? formed a comprehensive example of healing that functioned as a means to integrate traumatic memories into a personal narrative, a process outlined by nineteenth-century psychiatrist Pierre Janet and further elaborated in the last two decades by psychiatrist Bessel van der Kolk. Despite Salomon's attempts to assimilate traumatic events into her life story, this thesis considers the structural and 
visual evidence present in Life? or Theatre? that indicates that Salomon's integration was not completed with the conclusion of the series. Rather, following the contributions of psychiatrist Judith Herman to the clinical study of trauma, it submits that Salomon's series evinces an oscillation between the psychological states of intrusion and constriction: Life? or Theatre? presents a work in progress - a dialectic of trauma that was yet to be resolved. 
TABLE OF CONTENTS

PAGE

ACKNOWLEDGEMENTS...........................................................

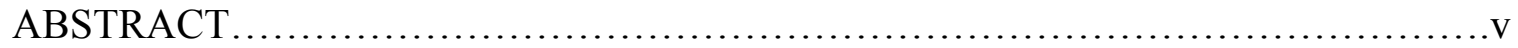

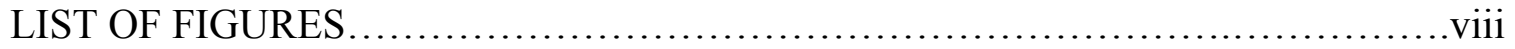

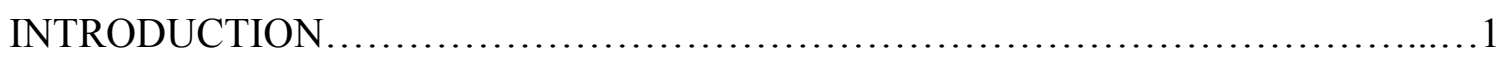

CHARLOTTE SALOMON'S BIOGRAPHY ....................................

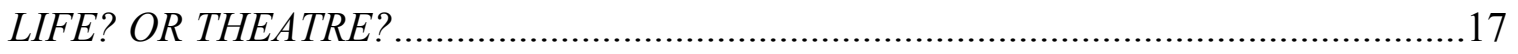

CURRENT HISTORIOGRAPHY ON LIFE? OR THEATRE? ........................................27

DIALECTIC OF TRAUMA:

READING INTEGRATION, INTRUSION, AND CONSTRICTION..................41

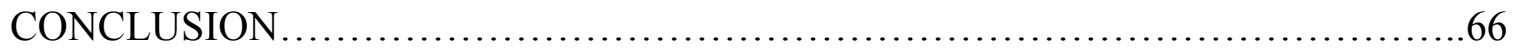

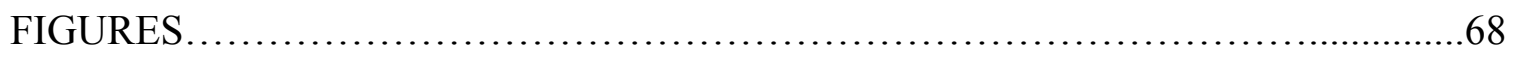

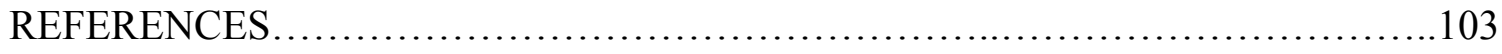

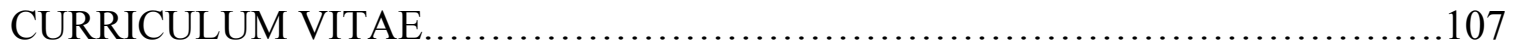




\section{LIST OF FIGURES}

FIGURE $^{1}$ PAGE

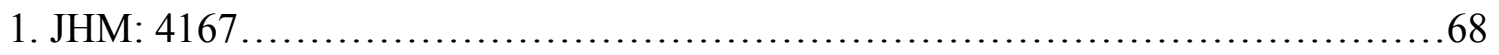

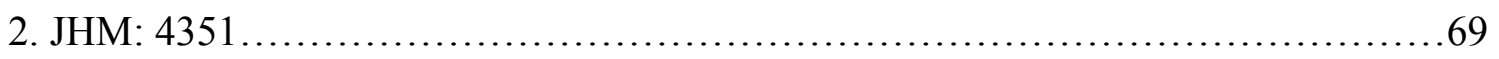

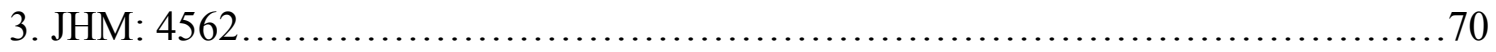

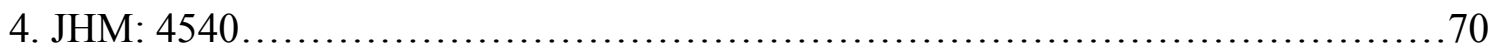

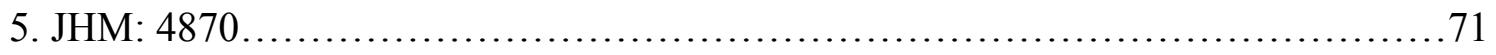

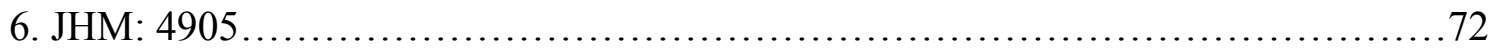

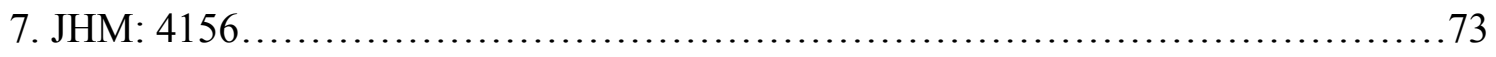

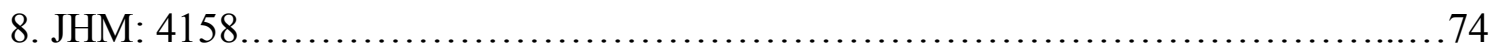

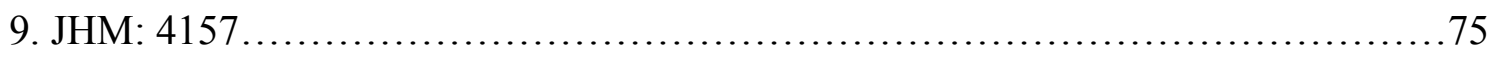

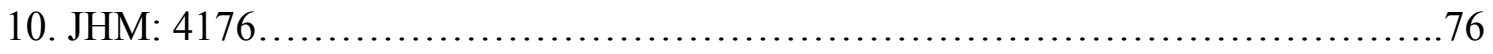

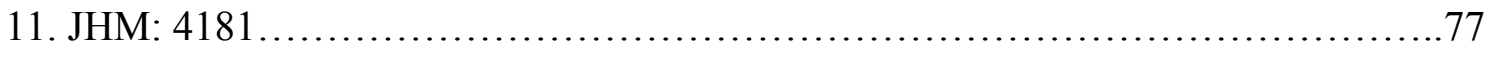

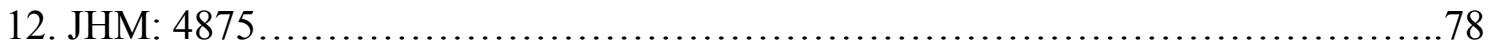

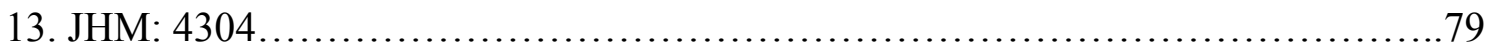

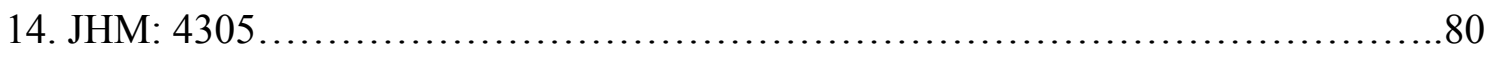

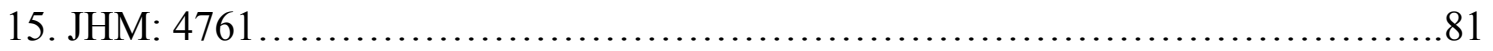

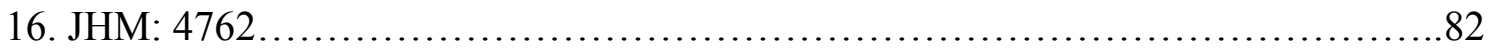

${ }^{1}$ All figure numbers are cited according to the Jewish Historical Museum's comprehensive catalog, Charlotte Salomon and Judith C.E. Belinfante, Charlotte Salomon: Life? or Theatre? (Zwolle, Netherlands: Waanders, 1998). 


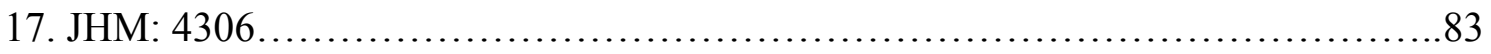

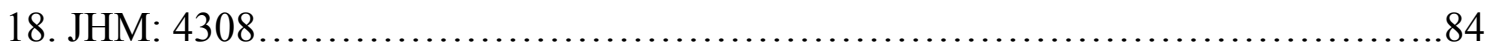

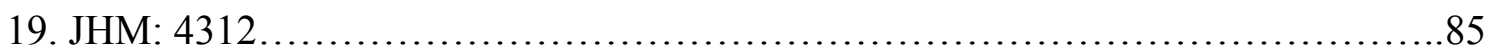

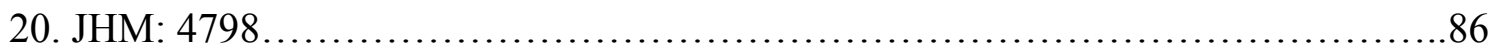

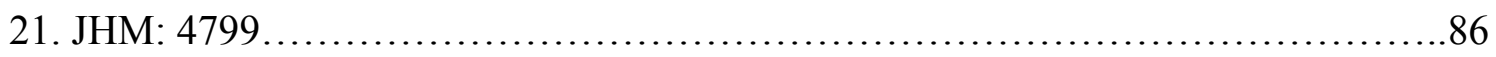

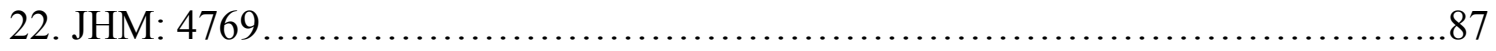

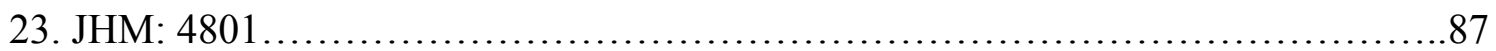

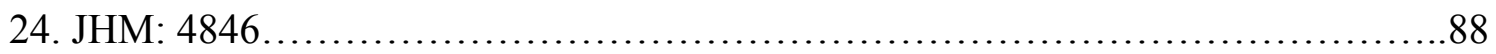

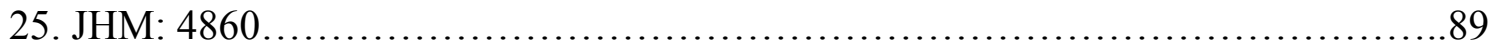

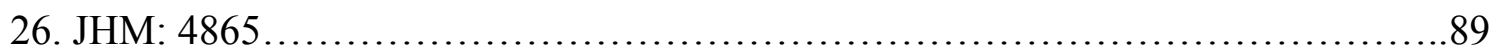

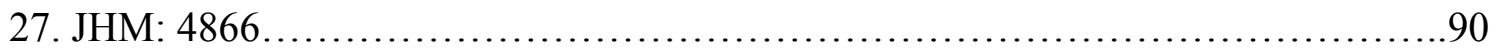

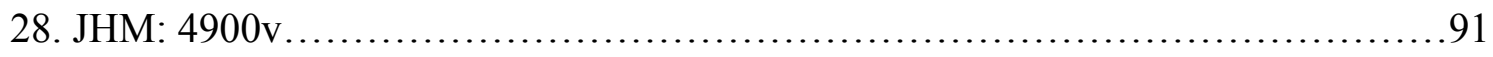

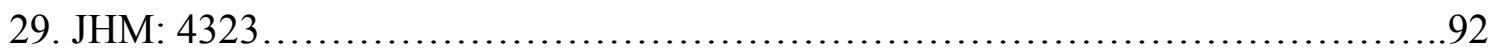

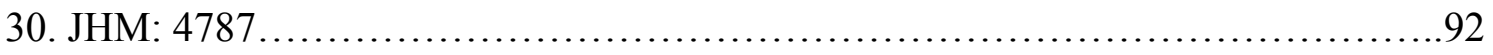

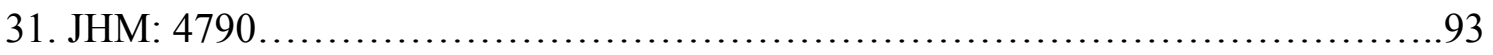

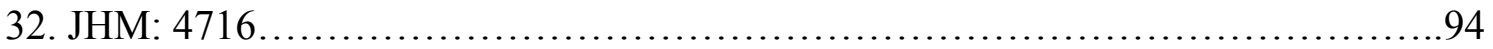

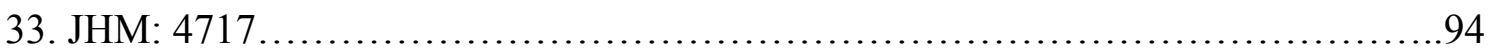

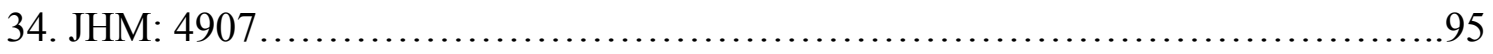

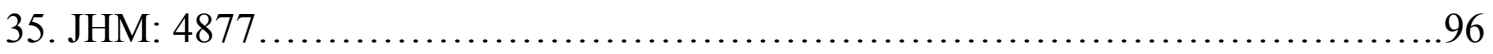

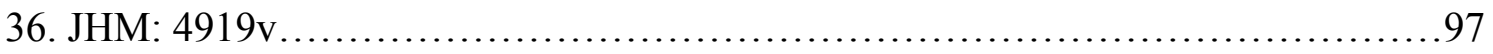

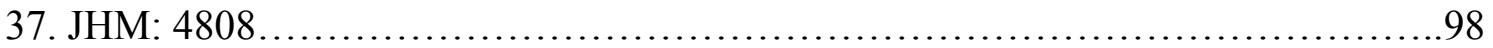

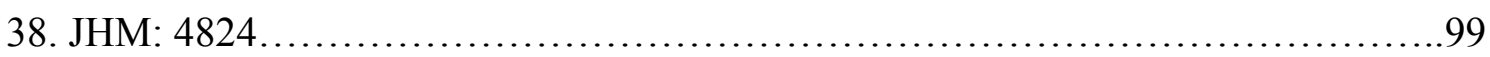

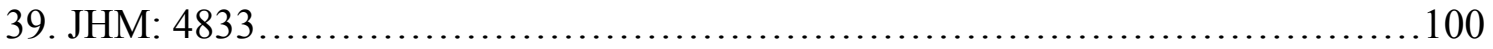




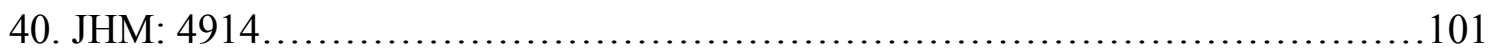

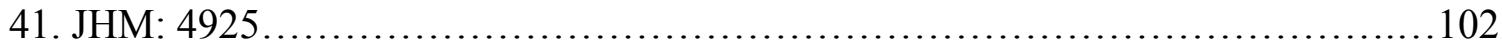




\section{INTRODUCTION}

Charlotte Salomon's Life? or Theatre? is a complicated story to navigate. In this series, which consists of more than seven hundred gouache paintings created over the duration of approximately eighteen months between 1941 and 1942, Salomon intertwined factual details from her childhood and adolescence with invented reenactments, a conflation that raises compelling questions about the formation and operation of memory, including traumatic memory. In order to explore the many facets of memory in Life? or Theatre?, I begin by outlining the facts of Salomon's life prior to the production of her operetta. I then discuss the way that Salomon combined color, text, music, autobiography, and reconstruction into a work of art that indicates her desire to organize painful memories into a narrative. I briefly outline the work of three scholars: Leah White, Ernst van Alphen, and Griselda Pollock, each of whom have offered theorizations of the function of Life? or Theatre? I draw upon their work in order to examine the degree to which the series reveals Salomon's attempt to contextualize and assimilate traumatic memories from both her adolescence and time spent in exile into the format of a narrative. I conclude by asserting that the series can be understood as a visual manifestation of psychologist Judith Herman's notion of the dialectic of trauma, an oscillation between the states of psychological intrusion and constriction, the presence of which may indicate that Salomon's attempts at integration were incomplete. 
In her book Trauma and Recovery: The Aftermath of Violence - from Domestic Abuse to Political Terror, Judith Herman describes traumatic events as those that "overwhelm the ordinary systems of care that give people a sense of control, connection, and meaning." "2 Likewise, the Comprehensive Textbook of Psychiatry states that the shared qualities of psychological trauma are "intense fear, helplessness, loss of control, and threat of annihilation."” After the extreme peril that Salomon and her family faced as Jews living in Berlin under the Third Reich, along with the other forms of antagonism to which she individually was subjected, including the suicide of several family members, she felt an urgent need to record her life in a way that confronted her tumultuous past.

For centuries, trauma has been associated with the effects of war, and psychiatrists throughout the course of the last one hundred fifty years have studied the consequences of battle on the individual psyche, including Sigmund Freud, Pierre Janet, and Abram Kardiner. In the 1970s, the term "post-traumatic stress disorder" (PTSD) was coined to signify the symptoms of veterans from the Vietnam and Korean Wars. ${ }^{4}$ However, as Herman points out, the rise of the feminist movement in the 1970s thrust the significance of the effects of rape, sexual assault, and domestic captivity into the sphere of discussion in relation to PTSD. ${ }^{5}$ Essentially, a vast number of traumatic instigators exist. Aside from war and sexual assault, other prompters of PTSD include: shock,

\footnotetext{
${ }^{2}$ Judith L. Herman, Trauma and Recovery: The Aftermath of Violence - from Domestic Abuse to Political Terror (New York: Basic Books, 1992), 33.

${ }^{3}$ N.C. Andreasen, "Posttraumatic Stress Disorder," in Comprehensive Textbook of Psychiatry, $4^{\text {th }}$ ed., ed. H. I. Kaplan and B. J. Sadock (Baltimore: Williams and Wilkins, 1985), 918-24, as quoted in Herman, Trauma and Recovery, 33.

${ }^{4}$ Kristine Stiles, "Shaved Heads and Marked Bodies: Representations from Cultures of Trauma," in Talking Gender: Public Images, Personal Journeys, and Political Critiques, edited by Nancy A. Hewitt, Jean F. O'Barr, and Nancy Rosenbaugh (Chapel Hill: University of North Carolina Press, 1996), 37.

${ }^{5}$ Herman, Trauma and Recovery, 30-32.
} 
concentration camp experiences, racism, natural disasters, political captivity, and psychological domination by religious cults. ${ }^{6}$ The behavioral response to various traumatic experiences includes: guilt, rage, vulnerability, detachment, and numbing. ${ }^{7}$ In this vein, I discuss the notion that Salomon's Life? or Theatre? is perhaps a visible symptom of trauma.

In part, this thesis asserts that Life? or Theatre? demonstrates an attempt to convert traumatic memories into narrative memory, an idea introduced by Pierre Janet in the late nineteenth-century and expanded on by Bessel van der Kolk, among others. In his essay "The Intrusive Past: The Flexibility of Memory and the Engraving of Trauma," and his book Traumatic Stress: The Effects of Overwhelming Experience on Mind, Body, and Society, van der Kolk outlines Janet's theories that discuss the way the brain manages memory. Initially, Janet distinguished between the automatic incorporation of experience and narrative memory. Automatic synthesis, or habit/implicit memory, is the integration of experience without much conscious thought as to what is occurring. ${ }^{8}$ For instance, reading a book or riding a bicycle are activities many people participate in, but they do not actively consider how they know how to read or ride. The inability to describe to another person how to read or the way to ride a bike does not affect physical aptitude. ${ }^{9}$

${ }^{6}$ Stiles, "Shaved Heads and Marked Bodies," 37.

${ }^{7}$ Ibid.

${ }^{8}$ Bessel van der Kolk and Onno van der Hart, "The Intrusive Past: The Flexibility of Memory and the Engraving of Trauma," in Trauma: Explorations in Memory by Cathy Caruth (Baltimore: Johns Hopkins University Press, 1995), 159-160.

${ }^{9}$ Richard J. McNally, Remembering Trauma (Cambridge: Harvard University Press, 2003), 30-31. 
Conversely, Janet distinguished habit memory from narrative memory, which consists of "mental constructs, which people use to make sense out of experience." type of memory is integrated and organized in the brain and subsequently shapes personality. For instance, childhood memories of family trips to the beach, bad first dates, and graduating from college are all memories that define a person and contribute to a life narrative, or "a personal story."11 Likewise, Janet thought that the "ease with which current experience is integrated into existing mental structures depends on the subjective assessment of what is happening." ${ }^{12}$ Usual or expected experiences are easier to integrate and are done so without much conscious thought, whereas frightening or unusual experiences may be difficult to fit into existing narrative schemes. Instead, these memories are dissociated, or split off, from normal, conscious awareness and therefore unavailable for ordinary retrieval. These dissociated memories result in the formation of traumatic memories. $^{13}$

According to Janet, accessing traumatic memories comes in the form of "physical sensations, horrific images, or nightmares." ${ }^{14}$ As opposed to organizing traumatic experiences in a linguistic manner that integrates into an existing personal story, in their dissociated state traumatic memories shock the mind with vivid, recurring mental images. Van der Kolk asserts that in order to integrate these memories into narrative language, one must return to these memories often, usually with the help of a licensed therapist.

\footnotetext{
${ }^{10}$ Van der Kolk, "The Intrusive Past," 160.

${ }^{11}$ Bessel A. Van der Kolk, Alexander C. McFarlane, and Lars Weisaeth, Traumatic Stress: The Effects of Overwhelming Experience on Mind, Body, and Society (New York: Guilford Press, 1996), 281, 296.

${ }^{12}$ Van der Kolk, "The Intrusive Past," 160.

${ }^{13}$ Ibid., 160-163.

${ }^{14}$ Ibid., 164.
} 
Upon recovery, the traumatic memory is given context, a place in a person's life story, and can be expressed in the form of speech instead of disturbing mental flashbacks. ${ }^{15}$

Herman echoes this need for therapeutic assistance in her book Trauma and Recovery. She outlines the ways in which victims of trauma come to terms with these horrific images and work to desensitize themselves to their shocking nature. The untransformed memory is described as "prenarrative," in which the memories are like film stills from a silent movie; however, "the goal of therapy is to provide the music and the words. ${ }^{, 16}$ Herman elucidates how, in a therapy setting, the patient may use nonverbal methods to construct the traumatic experience, including drawing or painting. Herman says that 'given the 'iconic' visual nature of traumatic memories, creating pictures may represent the most effective initial approach to these "indelible images." ${ }^{17}$ The ultimate goal in this process is to reach a point where the internal image of the traumatic memory has an accompanying narrative. At this stage, the traumatic memories begin to integrate into the patient's narrative memory, thereby lessening the intensity usually associated with the trauma and allowing the memory to be recollected like any other. ${ }^{18}$

Furthermore, Herman discusses the way that traumatic memories operate in the mind of a victim. She asserts that in the aftermath of trauma, humans may experience a psychological oscillation between two contradictory responses: intrusion and constriction. Intrusion consists of the reliving of the traumatic experience as if it were continuously happening in the present. Mentioned earlier, the traumatic memory manifests as vivid, fragmented sensations, prompting Herman to claim that the intense

\footnotetext{
15 Ibid., 172-176.

${ }^{16}$ Herman, Trauma and Recovery, 175.

${ }^{17}$ Ibid., 177.

${ }^{18}$ Ibid., 195.
} 
focus on "image without context, gives the traumatic memory a heightened reality." 19 Herman speculates that the repetitive reliving, or intrusion, of a traumatic event indicates an attempt, albeit unsuccessful, at healing, or reclaiming control over the original traumatic occurrence. Herman summarizes Janet's notion that the constant barrage of the traumatic memory provides the victim opportunities to restore some sense of "efficacy and power" in a situation where the traumatized person "remains confronted by a difficult situation, one in which he has not been able to play a satisfactory part, one to which his adaptation has been imperfect, so that he continues to make efforts at adaptation.,20

Herman briefly touches on the work of psychiatrist Mardi Horowitz, who proposes the idea that the phenomenon of intrusion indicates "spontaneous attempts to integrate the traumatic event." ${ }^{21}$ Horowitz suggests the concept of a "completion principle," which delineates the mind's innate ability to process new information in order to create and sustain the "inner schemata of the self and the world." ${ }^{22}$ However, trauma destroys these inner schemata. Horowitz postulates that unassimilated traumatic memories are stored in an alternate "active memory," which has an "intrinsic tendency to repeat the representation of contents. ${ }^{, 23}$ The trauma is resolved only when a new schemata is constructed, which allows for the understanding of the traumatic event. ${ }^{24}$ Herman also cites the work of psychoanalyst Paul Russell, who proposes that the "repetition compulsion" derives from what a victim "needs to feel in order to repair the

${ }^{19}$ Ibid., 38.

${ }^{20}$ Pierre Janet, Psychological Healing, trans. E. Paul and C. Paul (New York: Macmillan, 1925), 603, as quoted in Herman, Trauma and Recovery, 41.

${ }^{21}$ Herman, Trauma and Recovery, 41.

${ }^{22}$ Mardi Horowitz, Stress Response Syndromes (Northvale, NJ: Jason Aronson, 1986), 93-94, as quoted in Herman, Trauma and Recovery, 41.

${ }^{23}$ Ibid.

${ }^{24}$ Herman, Trauma and Recovery, 41. 
injury.. ${ }^{25}$ Russell assumes that the repetition compulsion is an attempt to "relive and master the overwhelming feelings of the traumatic moment. ${ }^{, 26}$

Herman claims that while reliving a trauma may offer an "opportunity for mastery," most victims do not seek out or welcome these intrusions. ${ }^{27}$ Instead, victims of trauma may go to great lengths to avoid the reenactment of traumatic memories due to the extreme levels of distress they cause. However, ignoring or banishing intrusive symptoms, although "self-protective in intent," leads to the further exacerbation of the post-traumatic syndrome, which can cause "a narrowing of consciousness, a withdrawal of engagement with others, and an impoverished life."28

As such, Herman calls the voluntary evasion of traumatic events and reenactments "constriction." The constrictive state is one in which traumatic events have been "disconnected from their ordinary meanings." 29 At the time of the trauma and beyond, Herman describes constriction as a condition where "perceptions may be numbed or distorted," and "time sense may be altered, often with a sense of slow motion, and the experience may lose its quality of ordinary reality. ${ }^{, 30}$ Herman then describes the feeling a victim may have of rising out of her body, much like an out-of-body experience: "the person may feel as thought the event is not happening to her, as though she is observing from outside her body, or as though the whole experience is a bad dream from which she

${ }^{25}$ Paul Russell, "Trauma, Repetition and Affect" (Paper presented at Psychiatry Grand Rounds, Cambridge Hospital, Cambridge, MA, 5 September 1990), as quoted in Herman, Trauma and Recovery, 41-42. Sigmund Freud originally coined the term "repetition compulsion."

${ }^{26}$ Herman, Trauma and Recovery, 42.

${ }^{27}$ Ibid.

${ }^{28}$ Ibid.

${ }^{29}$ Ibid., 43.

${ }^{30}$ Ibid. 
will shortly awaken." ${ }^{31}$ Herman recalls the testimony of a rape survivor who claims that when the rape occurred, she dissociated to a detached state: "I left my body at that point. I was over next to the bed, watching this happen." ${ }^{32}$ The survivor then recalls a similar detached state when she reenacted the trauma: "When I repicture the room, I don't picture it from the bed. I picture it from the side of the bed. That's where I was watching from. ${ }^{, 33}$ Dissociative states appear to protect victims during the initial traumatic experience, but their persistence beyond the original event may hinder their recovery.

Herman states that because the traumatic experience is walled off from ordinary consciousness, it precludes any attempt at integration. ${ }^{34}$ Victims of PTSD do not "allow themselves to think about" the meaning of the traumatic experience, because to do so would recall the pain and grief associated with the original event. ${ }^{35}$ However, as Herman writes, "in avoiding any situations reminiscent of the past trauma... traumatized people deprive themselves of those new opportunities for successful coping that might mitigate the effect of the traumatic experience.",36

After a traumatic event, Herman asserts that victims of trauma oscillate between intrusive and constrictive symptoms, a predicament she calls the dialectic of trauma. This oscillation indicates the desire for a victim to find a balance between these two states. Yet balance is exactly what is missing in the traumatized person. The dialectic of trauma is therefore a self-perpetuating cycle. Neither mental state fosters a healing environment, as

\footnotetext{
31 Ibid.

${ }^{32}$ Robin Warshaw and Mary P. Koss, I Never Called it Rape (New York: Harper \& Row, 1988), 56, as quoted in Herman, Trauma and Recovery, 43.

33 Ibid.

${ }^{34}$ Herman, Trauma and Recovery, 45.

35 Ibid., 46.

36 Ibid.
} 
both deny the victim an opportunity to integrate traumatic memories into a personal story. Terror, grief, and sadness continue to plague the victim long after the traumatic experience has occurred, and "live on in the dialectic of trauma."

This thesis contends that Life? or Theatre? denotes evidence of the psychological splitting outlined by Janet and van der Kolk. Following Herman, I propose that perhaps one of the unconscious purposes of creating Life? or Theatre? was a kind of selfprescribed therapy for Salomon; it is a method of giving traumatic memories language and context, therefore mitigating or eliminating the pain associated with them. In order to substantiate this assertion further, I review the work of White, van Alphen, and Pollock, who agree that Life? or Theatre? signifies an effort on Salomon's part to contextualize and narrate illustrated traumatic experiences. Despite this attempt, I consider the notion that Salomon's self-guided therapy was, in some ways, unsuccessful, or incomplete, as the series betrays the existence of the dialectic of trauma. Therefore, the primary questions I address in this thesis are the following: How is Salomon's work motivated by, or evidence of, an attempt to integrate traumatic memories into her narrative memory? What does the presence of the dialectic of trauma signify about her success in completing this task?

${ }^{37}$ Ibid., 47-50. 


\section{CHARLOTTE SALOMON'S BIOGRAPHY}

Salomon's parents, Albert and Franze (née Grunwald) Salomon, married in 1916 and moved in to a Jewish neighborhood in western Berlin. Albert was a prominent surgeon, while Franze worked as a nurse. Both Dr. and Mrs. Salomon were familiar with profound tragedy: he was orphaned as a child when his mother and father died in quick succession; Mrs. Salomon's younger sister, Charlotte Grunwald, committed suicide in 1913, leaving the surviving sister periodically glum and listless for the rest of her life. ${ }^{38}$

Charlotte, Dr. and Mrs. Salomon's only child, was born in Berlin on April 16, 1917. When Salomon was eight years old, her mother committed suicide by jumping out a window in their apartment after suffering from acute depression for many years. Instead of the truth, Salomon was told that her mother died of influenza in order to both protect her emotionally, and to preserve a sense of dignity within the community. ${ }^{39}$

It is important to consider in this context how prevalent suicide was among Jewish women in early twentieth-century Germany, and the lengths families went to keep it hidden. In her essay, "Historical Effacements," Darcy Buerkle discusses the frequency of suicide among German Jewish women during the Weimar Republic years. She asserts that many nineteenth- and early twentieth-century sociologists took an anti-Semitic

\footnotetext{
${ }^{38}$ Mary Felstiner, To Paint Her Life: Charlotte Salomon in the Nazi Era (New York: HarperCollins, 1994), 3-5. Much of the factual information in Felstiner's book comes from a series of interviews with Paula Lindberg Salomon, and other friends and distant family members.

${ }^{39}$ Ibid., 4-5. No one knows why Mrs. Salomon killed herself; no note was left behind.
} 
stance by assuming that suicide among Jews was "the result of insanity; too much inbreeding had caused mental collapse. ${ }^{, 40}$ The rising suicide rate was therefore seen as a legitimate link to degeneracy; a notion preyed upon by the right-wing print media in the late Weimar period. As a result, many middle-class German Jewish families were shamed when relatives committed suicide. Given this, it is not unusual that Mrs. Salomon's suicide was not publicized, nor is it unusual that Salomon would have been protected from this information. ${ }^{41}$

After her mother's death, Salomon encountered many years of isolation. Her father was occupied by his hospital work and had no time for Salomon in these formative years. Both of their lives changed drastically when, in 1930, Dr. Salomon married Paula Lindberg, a famous mezzo-soprano singer. Salomon was immediately enamored with Lindberg, and likewise, Lindberg took an instant liking to Salomon. Upon Lindberg's influence, the Salomon family began practicing various Jewish customs, such as lighting Sabbath candles; Salomon even had a bat mitzvah. This was foreign territory for Salomon, whose childhood was devoid of such religious adherence, as her father had rejected Orthodox Judaism early in his life. ${ }^{42}$

Beginning in 1933, the year Adolf Hitler, backed by the Nazi party, gained power in Germany, Jews were "forced into an era of 'dissimilation' - a process of separation and then segregation. ${ }^{43}$ For example, on April 1, 1933, the Nazis scheduled an official

\footnotetext{
${ }^{40}$ Darcy Buerkle, "Historical Effacements: Facing Charlotte Salomon," in Reading Charlotte Salomon, edited by Michael P. Steinberg and Monica Bohm-Duchen (Ithaca: Cornell University Press, 2006), 80.

${ }^{41}$ Ibid., 80-82.

${ }^{42}$ Felstiner, To Paint Her Life, 19-31.

${ }^{43}$ Marion A. Kaplan, "Jewish Women in Nazi Germany: Daily Life, Daily Struggles, 1933-1939," Feminist Studies 16, no. 3 (Autumn 1990): 583.
} 
boycott of Jewish businesses, which was essentially a plan for soldiers to stand outside Jewish stores and urge shoppers to "buy German.."44 Furthermore, the Nuremberg Laws of 1935 "structurally transformed Jewish identity in Germany from a religious or ethnoreligious group into a race. ${ }^{, 45}$ Sexual intercourse and intermarriage between Jews and Aryans was forbidden, as Aryans were considered pure Germans; Jews were not. ${ }^{46}$ In addition to these proscriptions, the "April Laws" of 1933 revoked the employment of Jews in the civil service, the legal and medical professions, and high schools and universities. ${ }^{47}$ Dr. Salomon was fired from his post at a renowned Berlin hospital, and was forced to find work at a Jewish hospital. ${ }^{48}$ Similarly, in September 1933, Jews were excluded from the Chambers of Culture, disallowing them to participate in the fields of art, film, and music. ${ }^{49}$ Lindberg was verbally attacked during performances and labeled in the Berlin press by critics as a "Jewish pig." ${ }^{, 50}$ However, her operatic talents were given an outlet after the creation of the Kulturbund, a Jewish Cultural Association formed and directed by musical conductor and family friend, Dr. Kurt Singer. Singer convinced the government, police, and the Gestapo to permit a "separate creative space, 'a kind of haven for Jewish artists." ${ }^{21}$ The resulting Kulturbund was an organization that orchestrated operas, theatre, and musical concerts performed by

${ }^{44}$ Ibid.

${ }^{45}$ Franklin A. Oberlaender, "My God, They Just Have Other Interests," The Oral History Review 24, no. 1 (Summer 1997): 27.

${ }^{46}$ Kaplan, "Jewish Women in Nazi Germany," 583.

${ }^{47}$ Ibid.

${ }^{48}$ Felstiner, To Paint Her Life, 30. Dr. Salomon signed a 1905 dissertation "Albert Salomon, of the Jewish faith," identifying him as a Jew and serving as justification for his firing.

${ }^{49}$ Kaplan, "Jewish Women in Nazi Germany," 587.

${ }^{50}$ Felstiner, To Paint Her Life, 30.

${ }^{51}$ Ibid., 32-33. 
and to the Jewish population in Germany. Lindberg was a principal singer in the operas performed by the Kulturbund in Berlin. ${ }^{52}$ Bearing in mind the closeness of Salomon and Lindberg's relationship, her involvement with this association later had an enormous impact on Salomon's magnum opus, Life? or Theatre?

Singer hired World War I veteran Alfred Wolfsohn to work as Lindberg's voice coach. Wolfsohn eventually became Salomon’s mentor and, allegedly, her lover, inspiring her with his numerous philosophical declamations. ${ }^{53}$ Considering that more than four hundred of the 769 gouache paintings from Life? or Theatre? contain or center on an interaction with Wolfsohn's character, it is evident that the relationship between he and Salomon influenced her ruminations about life, death, and what separates the two. ${ }^{54}$

In 1934, when Salomon was seventeen years old, she accompanied her maternal grandparents, Ludwig and Marianne Grunwald, on a trip to Italy. It was in Rome, among the ancient ruins and Renaissance works of art, where Salomon solidified her decision to pursue art. In 1936, against heavy odds, Salomon was admitted to the Berlin Academy of Fine Arts, where she studied painting. Courses at the Academy exposed her to a range of artists, including the work of Edvard Munch, Amadeo Modigliani, Henri Matisse, and

\footnotetext{
52 Ibid., 32.

${ }^{53}$ Ibid., 53. Lindberg refutes the notion that Salomon and Wolfsohn were lovers.

${ }^{54}$ Ibid., 40-61. For instance, Wolfsohn was enamored with the story of Orpheus, who braved the underworld to rescue his wife, Eurydice.
} 
Vincent van Gogh. ${ }^{55}$ Despite the fact that her work was good, according to her teachers, her enrollment was revoked in the summer of $1938 .^{56}$

Kristallnacht, which took place on the nights of November $9^{\text {th }}$ and $10^{\text {th }}, 1938$, was a turning point in the Nazi's efforts at Jewish eradication. This pogrom was set in motion after a young Polish (Jewish) man, whose parents had recently been deported from Germany, killed a German diplomat in France. Nazi "revenge" for this act of violence called for Germans to destroy Jewish businesses, set synagogues on fire, and torture any rounded up Jews. By the end of the night of the $10^{\text {th }}$, nearly one hundred Jews were dead, and more than thirty thousand were in route to concentration camps. ${ }^{57}$

Salomon's father was one of the many individuals captured and was imprisoned at the Sachsenhausen concentration camp, about fifteen miles outside of Berlin. Lindberg was desperate to get him out, and went to extreme measures to ensure his release. Profoundly affected by his incarceration, her father and Lindberg eventually made the decision that Salomon should leave Berlin and stay with her maternal grandparents, who had been living in France since 1934, until the dire situation in Berlin subsided. After obtaining (false) documents stating Salomon was to visit her grandparents for only a weekend, she left in January 1939. She never saw her father, stepmother, or Berlin again. $^{58}$

${ }^{55}$ Deborah Schultz and Edward Timms, "Charlotte Salomon: Images, Dialogues and Silences," Word \& Image 24, no. 3 (July-September 2008): 269. For more information on the type of education Salomon would have received at the Academy, see Christine Fischer-Defoy and Paul Crossley, "Artists and Art Institutions in Germany 1933-1945," Oxford Art Journal 9, no. 2 (1986): 16-29.

${ }^{56}$ Felstiner, To Paint Her Life, 34-39, 65. Her admission was revoked shortly after the Degenerate Art Exhibit passed through Berlin.

${ }^{57}$ Ibid., $75-79$.

${ }^{58}$ Ibid., 80-96. 
Salomon traveled to Villefranche, a few miles east of Nice, where she met up with her grandparents, who were staying in a villa called "the Hermitage." The villa was owned by Ottilie Moore, an American friend of the Grunwalds who had offered them refuge from Nazi Germany in 1934. Salomon spent most of her time sketching, avoiding other guests, and arguing with her grandmother. In early 1940, the three of them moved out of Moore's villa and into a mansion closer to Nice. This was where Mrs. Grunwald killed herself and Salomon's grandfather revealed to her that suicide was the typical "exit strategy" of numerous other family members, including her own mother. Previously unbeknownst to Salomon, this information was naturally distressing to her, and she was plagued by the possibility that she was doomed to follow in their footsteps. ${ }^{59}$ Salomon wrote, "When I found out that I was the only survivor and when deep within me I felt the same inclination, the urge towards despair and towards dying."

Pressure on Jewish refugees was mounting in May and June 1940. Many French citizens assumed that exiled Germans were Nazi spies, and the main cause of France's declining success in keeping the Nazis out of their country. As a result, one newspaper in Nice printed that "German nationals must present themselves at the Gurs center"- a deportation camp in the French Pyrenees near the Spanish border. ${ }^{61}$ Both Salomon and her grandfather were imprisoned at Gurs from June to July 1940; Salomon was released in July in order to return to Nice and care for her aged grandfather. ${ }^{62}$

\footnotetext{
${ }^{59}$ Ibid., 101-109.

${ }^{60}$ Danielle Knafo, In Her Own Image: Women's Self-Representation in TwentiethCentury Art (Madison, NJ: Fairleigh Dickinson University Press, 2009), 63.

${ }^{61}$ Felstiner, To Paint Her Life, 117-118.

${ }^{62}$ Ibid., 123. Her grandfather was released the same day.
} 
In 1941, Salomon moved away from Nice and her grandfather to a nearby town, St. Jean Cap Ferrat, settling in a hotel called La Belle Aurore. It was here that Salomon painted Life? or Theatre?, working on the series consistently from late summer 1941 until summer 1942. Guests at the hotel remember Salomon as a cheerful woman who was always serious, always humming, and always painting. ${ }^{63}$

After the death of her grandfather in February 1943, Salomon moved back to Nice in May, and in June 1943 she married Alexander Nagler, an Austrian Jew who fled to France in 1938. Nagler was Ottilie Moore's former lover, and according to some of Salomon's fellow refugees a dull, drunk, obtuse man. Nonetheless, Salomon had become pregnant, prompting the two of them to marry. ${ }^{64}$

In November 1942, Italian authorities had taken control of Nice, and although aligned with the Axis powers, were "dispassionate about deporting Jews." ${ }^{65}$ By August 1943, however, Nazi officials had grown increasingly intolerant of the Italian occupation and decided to take matters into their own hands. Salomon and Nagler were among those captured on September 24, 1943, and were sent eastward to Auschwitz on October 7. Salomon reached Auschwitz on October 10, where she was murdered upon arrival, presumably because she was pregnant. ${ }^{66}$ After the war, Dr. Salomon and Lindberg, having survived by hiding in Amsterdam, traveled to France to meet Moore, who gave them Life? or Theatre? The Salomon family gave the series to the Jewish Historical Museum in Amsterdam in 1971, where it resides today. ${ }^{67}$

\footnotetext{
${ }^{63}$ Ibid., 141-142.

${ }^{64}$ Ibid., 167-172.

65 Ibid., 161.

${ }^{66}$ Ibid., 186-203. Nagler was killed at Auschwitz in January 1944.

${ }^{67}$ Ibid., 217, 228. They did so at the urging of Otto Frank, Anne Frank’s father.
} 


\section{LIFE? OR THEATRE?}

The series Salomon produced is vast and comprehensive; from 1941 to 1942, she painted more than 1,300 separate works, with the final product, Life? or Theatre?, consisting of 769 gouache paintings on 13" x 10" paper sheets. These sheets reveal details of Salomon's life, spanning from 1913, the year in which her aunt, Charlotte Grunwald, committed suicide, until 1940, a few weeks after her return from Gurs. Each painting is dedicated to Salomon's attempt to overcome the ostensible insanity that was closing in on her; in 1940 she wrote to her father and Lindberg, "I will create a story so as not to lose my mind." ${ }^{68}$

The first page of the work contains the title, Life? or Theatre?, while the subtitle, containing the letters "CS," describes the work as a singspiel. On the following page, Salomon dedicates the work to Ottilie Moore in the top right corner, and in the middle of the same page, explains to the audience that the work consists of three parts: a Prelude, a Main Section, and an Epilogue. The third page is entitled "The tri-colored play with music begins," and, much like a playbill, lists the characters in the operetta. ${ }^{69}$

${ }^{68}$ Ibid., 100-112. This line is from a letter sent to Dr. Salomon and Lindberg in Amsterdam, where the two of them fled soon after Salomon left for France. This letter was among the last exchanged between Salomon and her parents, as communication was eventually cut off between France and Holland.

${ }^{69}$ Charlotte Salomon and Judith C. E. Belinfante, Charlotte Salomon: Life? or Theatre? (Zwolle, Netherlands: Waanders, 1998), 43; JHM: 4155-3. Contemporary research shows that red, yellow, blue, and white are the only colors employed in the operetta. Citations of paintings from Life? or Theatre? include the page number in the Salomon and Belinfante volume, followed by its Jewish Historical Museum (JHM) catalog number. 
The cast of characters in Life? or Theatre? consists of thinly disguised significant figures from Salomon's life. Narrator "CS" gave them all nicknames, never referring to them directly. For instance: her father is renamed Albert Kann; Lindberg is called Paulinka Bimbam; her grandparents become Dr. and Mrs. Knarre; Kurt Singer is Dr. Singsong; Alfred Wolfsohn is Amadeus Daberlohn. The names given to Lindberg, Wolfsohn, and Singer are obvious references to music. "Bimbam" and "Singsong" are onomatopoeic, whereas "Amadeus" refers to Amadeus Mozart. ${ }^{70}$ Salomon never referred to herself in the first person; instead Salomon becomes "Charlotte Kann," and is consistently spoken of in the third person throughout the series. ${ }^{71}$

The Prelude begins with the suicide of Salomon's aunt in 1913 and continues until the mid-1930s, well into the Nazi regime. The Prelude contains details of her mother's suicide, her father's marriage to Lindberg, the 1933 April boycotts, the creation of the Kulturbund, and her time at the Berlin Academy of Fine Arts. The Main Section outlines the supposed love affair between Salomon and Daberlohn, as well as the persecution endured by the Jewish community until 1939, when Salomon was sent to stay with her grandparents. The Epilogue delineates Salomon's exile experiences in France. The final part of the series includes her grandmother's suicide, and her grandfather's revelation of the familial tendency toward suicide, including that of her mother, a shock that would change her life and eventually inspire her to take on something "wildly

\footnotetext{
${ }^{70}$ Griselda Pollock, "Theater of Memory: Trauma and Cure in Charlotte Salomon's Modernist Fairytale," in Reading Charlotte Salomon, 35.

${ }^{71}$ Salomon and Belinfante, Charlotte Salomon: Life? or Theatre?, 32.
} 
eccentric.. ${ }^{, 2}$ The series ends in 1940, with Salomon sitting on the beach, about to embark upon the task of creating Life? or Theatre?

Many of the paintings in the Prelude are conflations of numerous incidents. Salomon's use of this compositional strategy alerts viewers to the passage of time by sectioning the action into horizontal bands or a grid. ${ }^{73}$ For instance, the painting JHM: 4167 (Figure 1) features along the top of the page Dr. and Mrs. Salomon parting ways at a train station because, being a soldier, he must return to the war. In the same image, further down in the center of the painting, Mrs. Salomon declines her parents' offer to come live with them after her husband leaves. Instead, as is indicated at the bottom of the page, she chooses to return to the home she shares with Dr. Salomon. ${ }^{74}$

In other paintings, the imagery swirls around the page, in a style reminiscent of Marc Chagall. ${ }^{75}$ JHM: 4351 (Figure 2), for example, details Salomon's fascination with painting and drawing after having worked with a tutor, and contains repeated images of her engrossed in her art. In homage to Vincent van Gogh, Salomon visualizes her intense concentration in three versions of herself floating in the picture plane amongst a sunflower, chair, and a pair of shoes. ${ }^{76}$

The Main Section depicts several conversations, usually between Salomon and Lindberg, or Salomon and Wolfsohn. As a result, there are numerous illustrations of two people talking against a white background, with their face or body, usually in profile,

\footnotetext{
${ }^{72}$ Michael P. Steinberg, "Reading Charlotte Salomon: History, Memory, Modernism," in Reading Charlotte Salomon, 6-7.

${ }^{73}$ Raphael Rubenstein, "Charlotte Salomon: A Visual Testament," Art in America 87, no. 1 (January 1999): 80.

${ }^{74}$ Salomon and Belinfante, Charlotte Salomon: Life? or Theatre?, 58; JHM: 4167.

${ }^{75}$ Rubenstein, "Charlotte Salomon: A Visual Testament," 80. For the Chagall reference, see Felstiner, To Paint Her Life, 67.

${ }^{76}$ Salomon and Belinfante, Charlotte Salomon: Life? or Theatre?, 233; JHM: 4351.
} 
accompanied by narration or dialogue. Likewise, Salomon portrayed many instances of Wolfsohn alone, talking incessantly about his philosophical interests. In these painted soliloquies, Salomon accompanies them with repeated versions of his face or stretched, elongated body (Figures 3 and 4). The paintings and narration work in tandem to express Wolfsohn's fascination with the connection "between the soul and artistic expression.,"77

The visual images in the Epilogue lack the precision and articulation of those from the Prelude or the Main Section. Thick, painterly brushstrokes outline the figures in the scenes, usually shown in profile, while other body features are either missing or loosely rendered. Interior settings are minimal, with perhaps a few lines painted to represent a bed or window frame. ${ }^{78}$ As will be discussed later, the narration or dialogue plays a vital role in the Epilogue, as the text seems to take up an increasing amount of space within the painting, almost resembling graffiti (Figure 5) ${ }^{79}$

The hasty painting technique in the Epilogue has been accounted for by scholars who assert that Salomon may have felt that as time moved forward she sensed the impending doom that would eventually take her life, thus indicating that she was, as Judith Herzberg contends, "racing against time to capture the entire experience of life as completely and quickly as possible. ${ }^{, 80}$ However, others such as Susanna Partsch argue that the crudely rendered paintings in the Epilogue were a conscious choice, and that Salomon "chose the stylistic device she used according to the situation she wanted to

${ }^{77}$ Ibid., 20, 443, 421 JHM: $4562 \& 4540$.

${ }^{78}$ Rubenstein, "Charlotte Salomon: A Visual Testament," 83.

${ }^{79}$ Salomon and Belinfante, Charlotte Salomon: Life? or Theatre?, 757; JHM: 4870. See also Ernst van Alphen, Caught by History: Holocaust Effects in Contemporary Art, Literature, and Theory (Stanford: Stanford University Press, 1997), 84.

${ }^{80}$ Judith Herzberg, Charlotte: Life? or Theatre? An Autobiographical Play by Charlotte Salomon (New York: Viking Press, 1981), viii, as quoted in Claudia Barnett, "Painting as Performance," The Drama Review 47, no. 1 (Spring 2003): 119. 
paint.. ${ }^{, 11}$ Either way, the paintings in the final portion of Life? or Theatre?, despite their lack of definition, are powerful, and evoke a pervading sense of fear and madness that Salomon experienced during her time in France.

Color is an expressive indicator of mood and disposition throughout the series. For instance, murky blue tones were used when indicating the way in which her mother sank into a depression from which she never recovered; dark browns were used to indicate Nazi actions of brutality and conformity; while bright yellows and greens were used to indicate happier times, such as family vacations. ${ }^{82}$ Salomon's meticulous use of color and linear drawing style suggest the influence of German Expressionists such as Otto Dix, Max Beckmann, and Ernst Ludwig Kirchner. ${ }^{83}$ However, as van Alphen asserts, this Expressionist interpretation does not take into account Salomon's use of text and musical quotations. The categorization of Life? or Theatre? as strictly Expressionist fails to encompass the inter-textual relationship between image, text, and music. ${ }^{84}$ Approximately the first two hundred paintings in Life? or Theatre? are covered by thin, transparent overlay sheets. These sheets are inscribed with pencil; the written text functions as both the character's speech and a descriptor of action taking place in the painting beneath. However, after presumably running out of overlays, Salomon was, on a technicality, forced to position the text within the paintings. She narrated many of the remaining sheets in the series by applying gouache directly onto the painting alongside the characters. In this way, the text serves as a primary element in the composition.

${ }^{81}$ Susanna Partsch, "Charlotte Salomon: Anmerkungen zu einem Zyklus." Kritische Berichte 10, no. 4 (1982): 50, as quoted in Claudia Barnett, "Painting as Performance," 119.

${ }^{82}$ Salomon and Belinfante, Charlotte Salomon: Life? or Theatre?, 32.

${ }^{83}$ Schultz and Timms, "Charlotte Salomon: Images, Dialogues and Silences," 269.

${ }^{84}$ Ernst van Alphen, Caught by History, 67. 
Salomon's incorporation of text and image forces viewers to both look at the visuals and read the accompanying commentary for clarity; she wrote on a discarded sheet that, "In order to facilitate the reader's understanding, explanatory texts have been attached to many sheets. ${ }^{85}$ The text describes the action in the images, provides dialogue for the characters, and occasionally offers access to the internal musings of the characters in the singspiel. The images are enhanced by the "verve of the dialogue and the ironies introduced by the artist's narrative voice. ${ }^{\prime 86}$ For instance, on the subject of her mother's suicide, Salomon's use of narration and dialogue allows for numerous characters in the series, including Mr. Salomon, Lindberg, and Mrs. Grunwald, to contemplate the reason that Mrs. Salomon killed herself. Thus, the integration of image and text enabled Salomon to extrapolate and articulate complex issues in unique terms. ${ }^{87}$ Initially, the text in the overlays played a more explanatory role in the series, serving as a way of narrating what occurs in the image beneath it. However, narration is gradually supplanted by dialogue, thereby highlighting further "the thoughts and feeling of the characters and their conversational exchanges. ${ }^{.88}$ Additionally, the text in the overlays occasionally takes on an expressive role. For example, Felstiner notes that in Salomon's depiction of the Pope during her trip to Rome, the Pontiff asks, "What are

${ }^{85}$ Schultz and Timms, "Charlotte Salomon: Images, Dialogues and Silences," 270.

${ }^{86}$ Edward Timms and Deborah Schultz, "Charlotte Salomon's Life? or Theatre?: A Multimedia Response to the Crisis of German Culture," Word \& Image 24, no. 3 (JulySeptember 2008): 254.

${ }^{87}$ Ibid., 253-254.

${ }^{88}$ Schultz and Timms, "Charlotte Salomon: Images, Dialogues and Silences," 271. 
those little Jews doing here?" In the overlay, his words spill down his robe in the image beneath, and appear to poke Salomon. ${ }^{89}$

Once Salomon began applying the text directly to the paper, the words "become looser, painted in varying sizes to create tension and enhance the visual composition." 90 The text, initially designed to fit around the characters, eventually gains equal importance as the image, and assumes a more aggressive, dramatic role. ${ }^{91}$ For instance, JHM: 4905 (Figure 6), a painting from the Epilogue, depicts Dr. Grunwald in bed after having told Salomon about the familial tendency toward suicide, wondering whether or not she will meet the same fate. ${ }^{92}$ The text essentially covers his entire body, perhaps indicative of an attempt for Salomon to negate, or cover up, his insensitive prophecy. ${ }^{93}$

In addition to being both read and viewed, Salomon created a "musical soundtrack" as well. On the fifth page of Life? or Theatre?, Salomon describes for the audience how she worked:

The creation of the following paintings is to be imagined as follows: A person is sitting beside the sea. He is painting. A tune suddenly enters his mind. As he starts to hum it, he notices that the tune exactly matches what he is trying to commit to paper. A text forms in his head, and he starts to sing the tune, with his own words, over and over again in a loud voice until the painting seems complete. ${ }^{94}$

The songs she chose, which include selections from Schubert, Beethoven, and Bach, enliven further the action in Life? or Theatre $?^{95}$ For example, they bring Lindberg's

${ }^{89}$ Felstiner, To Paint Her Life, 35, as quoted in Schultz and Timms, "Charlotte Salomon: Images, Dialogues and Silences," 216.

${ }^{90}$ Schultz and Timms, "Charlotte Salomon: Images, Dialogues and Silences," 272.

${ }^{91}$ Ibid.

${ }^{92}$ Salomon and Belinfante, Charlotte Salomon: Life? or Theatre?, 793; JHM: 4905.

${ }^{93}$ van Alphen, Caught by History, 87.

${ }^{94}$ Salomon and Belinfante, Charlotte Salomon: Life? or Theatre?, 35.

${ }^{95}$ Timms and Schultz, "A Multimedia Response to the Crisis of German Culture," 255. 
concerts to life, as the audience is given access to the song being performed in the image, and is perhaps encouraged to sing along.

Another function of music in the series is to occasionally serve as leitmotifs, such as Bach's "Be thou with me," which are "aesthetically transposed into the defining structure of the music drama. ${ }^{, 96}$ The recurring songs also provide irony in the operetta. For instance, the bridal song from Weber's Der Freischutz, "We Twine for thee the Maiden's Wreath," is played at the marriage of Dr. and Mrs. Salomon in the Prelude, and again after Salomon is conceived by her parents. However, the bridal song also accompanies the images of Mrs. Salomon's death; the song that once served as a joyful melody transforms into a funeral dirge. ${ }^{97}$

Life? or Theatre? evokes many characteristics of the cinema, through its use of text, image, and song. Silent movies of the 1920s, according to scholars Timms and Schultz, "relied on flickering images linked by simplistic inter-titles and accentuated by a pianist thumping out musical improvisation." ${ }^{98}$ When Salomon's work was exhibited in 1998 at the Royal Academy in London, one reviewer commented that her collection of paintings "resemble, at times, a director's storyboard," in that her variation in "rhythm and changes of focus," from close-ups and wide-angle shots, seem to bear in mind the "varied tempo of film and the flexibility that the camera offers the director." ${ }^{" 99}$ Likewise, Salomon's use of repetition is comparable to individual film stills and show detailed movement or sequence of events.

\footnotetext{
${ }^{96}$ Ibid.

${ }^{97}$ Ibid., 255. See also van Alphen, Caught by History, 81-83.

98 Timms and Schultz, "A Multimedia Response to the Crisis of German Culture," 260.

${ }^{99}$ Richard Cork, "A Short Life in Red, Yellow, and Blue," The Times 27 (October 1998): 39, as quoted in Timms and Schultz, "A Multimedia Response to the Crisis of German Culture," 260.
} 
The use of flashbacks within the drama allows Salomon to recover necessary information and offers viewers a better understanding of her characters. ${ }^{100}$ For example, in the Prelude, Salomon paints a series of images from her grandmother's perspective that recall her marriage and the self-inflicted deaths of her brother and two daughters. In this way, viewers are better acquainted with Mrs. Grunwald and comprehend further her mental decline later in the Epilogue.

Three primary themes surface in Life? or Theatre?: how Salomon and her family were affected by Nazi oppression as Jewish, German citizens in the era leading up to the Holocaust; the complicated relationship between Salomon and Wolfsohn; and how Salomon responded to the revelation that numerous family members committed suicide. Although Life? or Theatre? is an extraordinary record of the oppression experienced by Jews living in Berlin during the years prior to what would manifest as the Holocaust, Salomon's depictions of the persecution that she and her family endured seem to serve more as a backdrop against which the story of her family's history unfolds. Likewise, while more than half of the images contain or refer to Wolfsohn, his philosophical reflections, and their supposed romantic interludes, Salomon's preoccupation with suicide seems to dictate the overall structure of the series. The paintings she created that feature this issue seem to act as keystones in this work. For example, the first image in Life? or Theatre? illustrates the events leading up to her aunt's suicide, while one of the last images depicts a conversation that ends with Salomon's grandfather suggesting she kill herself. ${ }^{101}$ Viewers begin, end, and are reminded throughout the series of Salomon's

\footnotetext{
${ }^{100}$ Timms and Schultz, "A Multimedia Response to the Crisis of German Culture," 260.

${ }^{101}$ Salomon and Belinfante, Charlotte Salomon: Life? or Theatre?, 47, 814, JHM: 4156 \& 4920v, respectively.
} 
preoccupation with suicide. Furthermore, one of the reasons the work was created to begin with was to subvert her anxiety about suicide; near the end of the series, Salomon explains that she will either commit suicide or undertake something "wildly eccentric."102 That something "wildly eccentric" was Life? or Theatre?, an outlet for her to reconstruct and work through her tumultuous past.

${ }^{102}$ Ibid., 817; JHM: 4922r. 


\section{CURRENT HISTORIOGRAPHY ON LIFE? OR THEATRE?}

Selections from Life? or Theatre? were put on display for the first time in 1961 at the Stedelijk Museum, an exhibition curated by Ad Petersen. They were also shown in Israel, an exhibit that was visited by Chagall, who said the paintings were "good - they were good." ${ }^{, 103}$ A book entitled Charlotte: A Diary in Pictures followed in 1963, which likened Life? or Theatre? to that of Anne Frank's diary; the more optimistic parts of Salomon's magnum opus were highlighted. Throughout the remainder of the 1960s, the works were shown in Tel Aviv and galleries in Germany. After this initial tour, however, Life? or Theatre? was put in "five handmade cartons in the Salomons' flat while its subjects tried to get on with life." ${ }^{, 104}$

As previously mentioned, the Salomons gave Life? or Theatre? in its entirety to the Jewish Historical Museum in 1971. Ten years later, this institution mounted 250 scenes from the series in an extraordinarily popular show. Likewise, a feature-length film entitled Charlotte, which reconstructed her life and the creation of Life? or Theatre?, was released, and a play called Life? or Theatre? was performed at the Jerusalem Drama Workshop. Also in 1981, a book entitled Life? or Theatre? was published. This edition

${ }^{103}$ Felstiner, To Paint Her Life, 228.

${ }^{104}$ Ibid. 
by art historian Gary Schwartz includes color plates of all 769 paintings and their accompanying English captions from Life? or Theatre ${ }^{105}$

In 1986, works from Life? or Theatre? traveled to Berlin, and were shown in the same academy where Salomon was expelled nearly fifty years prior. In the 1990s, paintings from Life? or Theatre? were shown in Japan, Norway, and France. ${ }^{106}$ They were also displayed in Boston in 1996, London in 1998, and New York in 2001. ${ }^{107}$ Selections from Life? or Theatre? will be on view at the Contemporary Jewish Museum in San Francisco from March to July $2011{ }^{108}$

In the years following the 1981 release of Schwartz's Life? or Theatre?, there has been an increasing amount of critical interest in the series. This interest has been guided and supplemented by the comprehensive biography authored by historian Mary Felstiner. Published in 1994 and entitled To Paint Her Life: Charlotte Salomon in the Nazi Era, this biography pieces together Salomon's life from her birth, to her creation of Life? or Theatre?, and culminates with her untimely death at Auschwitz. In this book, Felstiner compiled information garnered from conducting numerous interviews with those who knew Salomon, including Lindberg, who could give details about her adolescence as well as her life in exile. Felstiner's book is an exploration of Salomon's life and work, and

\footnotetext{
${ }^{105}$ Ibid., 229. An updated volume was published in 1998: Salomon and Belinfante, Charlotte Salomon: Life? or Theatre? Neither version includes images of the transparent overlays. Text from the overlays is written in caption form above the reproduced image. 106 Ibid., 230.

${ }^{107}$ Reesa Greenberg, "The Aesthetics of Trauma: Five Installations of Charlotte Salomon's Life? or Theatre? in Reading Charlotte Salomon, 148-166. This is not an exhaustive list of exhibition sites. For further reading about Salomon in the museum, see Rubenstein, "Charlotte Salomon: A Visual Testament," and Judith S. Goldstein, "Alone with Charlotte Salomon," Partisan Review 69, no. 1 (Winter 2002): 75-77.

108 Charlotte Salomon: Life? or Theatre? "Exhibition on view March 31, 2011-July 31, 2011," http://www.thecjm.org/index.php?option=com_ccevents $\&$ scope $=$ exbt\&task $=$ detail\&oid $=4$.
} 
tries to complete what the author assumes to be one of the fundamental tasks proposed in Life? or Theatre? - in Felstiner's words, "Unravel this story. See if it's true.",109

The series proposes a number of challenges and avenues of interpretation to critics, which include: its defiance of period or stylistic grouping; the work as a representation of Jewish customs or the Holocaust; and its investigation of memory. ${ }^{110}$ However, given the interests and parameters of this thesis, a discussion of the first two issues will not be undertaken here, but rather will focus specifically on Salomon's traumatic experiences and how she managed the memories of them. To this end, I will outline the work of three scholars, White, van Alphen, and Pollock, whose essays directly refer to the traumatic events represented in Salomon's series and whose interpretations inform my discussion pertaining to the presence of the dialectic of trauma in Life? or Theatre?

${ }^{109}$ Felstiner, To Paint Her Life, xii. Nearly every essay I encountered while researching Salomon refers to this book. Other essays by Felstiner include: "Taking Her Life-History: the Autobiography of Charlotte Salomon," in Life Lines: Theorizing Women's Autobiography, edited by Bella Brodzki and Celeste Marguerite Schenck (Ithaca: Cornell University Press, 1988); “Charlotte Salomon's Inward-turning Testimony," in Holocaust Remembrance: The Shapes of Memory, by Geoffrey H. Hartman (Oxford: Blackwell, 1994); and "Create Her World Anew: Seven Dilemmas in Re-Presenting Charlotte Salomon," in Reading Charlotte Salomon, 194-211.

${ }^{110}$ The defiance of compartmentalization is mentioned in nearly every essay written about Life? or Theatre? Works that discuss this in more detail include: Barnett, "Painting As Performance"; Schultz and Timms, "Charlotte Salomon: Images, Dialogues and Silences," and Timms and Schultz, "Charlotte Salomon's Life? or Theatre?: A Multimedia Response to the Crisis of German Culture." For further reading about the link between the series and the Holocaust or Jewish aspects of Life? or Theatre? see Steinberg, "Reading Charlotte Salomon: History, Memory, Modernism," in Reading Charlotte Salomon, 1-20; Bohm-Duchen, "A Life Before Auschwitz," in Reading Charlotte Salomon, 21-33.; Astrid Schmetterling, "Inscriptions of Difference in Charlotte Salomon's Work," in Reading Charlotte Salomon, 140-147; Griselda Pollock, Encounters in the Virtual Feminist Museum: Time, Space and the Archive (London: Routledge, 2007); and Lisa Siverman, "Reconsidering the Margins: Jewishness as an Analytical Framework," Journal of Modern Jewish Studies 8, no. 1 (March 2009): 103120. 
In 2004, White wrote an essay entitled "Autobiography, Visual Representations, and the Preservation of Self," in which she examined "how Salomon in her autobiography uses a combination of written text and visual representations to create an extraordinary work of resistance and preservation." ${ }^{, 111}$ White contends that Nazi oppression is a primary source of trauma discussed in this essay, as Salomon spent most of her adolescence mired in "social turmoil and racial discrimination," which "weighed heavily on her." ${ }^{112}$ She asserts that Salomon's autobiography, Life? or Theatre?, thereby serves as "a powerful statement of resistance against oppressive forces."113

White enters into a discussion of the function of autobiography as it relates to the link between trauma and visual expression. White posits the notion that "autobiography is effective as a means to help one confront traumatic experiences" and that "it can function as a powerful tool of resistance and personal redefinition." She also claims that autobiography allows victims the opportunity to mold their subjectivities in a way that counters outside forces that "seek to control and shape them." Additionally, White outlines the idea that artistic expression is an effective way of representing traumatic events in a cohesive, non-threatening manner. She asserts that "although writing about

${ }^{111}$ Leah White, "Autobiography, Visual Representations, and the Preservation of Self," Mosaic: A Journal for the Interdisciplinary Study of Literature 37, no. 2 (2004): 107, http://search.proquest.com/docview/205344913?accountid=14665 (accessed January 12, 2011). White writes further about Salomon's Life? or Theatre? and its link to identity, subjectivity, and postmodern feminist theories. See White's "Life? or Theatre?: A Text of Incongruity and Fragmented Subjectivity" (Ph.D. diss., Arizona State University, 1997); and "Autobiography as Performative Identity Construction: The Fragmented Subjectivities of Charlotte Salomon," Text and Performance Quarterly 21, no. 2 (2001): 77-94. For another reading of Life? or Theatre? as autobiography, see Carolyn F. Austin, "The Endurance of Ash: Melancholia and the Persistence of the Material in Charlotte Salomon's Leben? oder Theater?" Biography 31 no. 1 (Winter 2008): 103-132.

${ }_{112}^{112}$ White, "Autobiography, Visual Representations, and the Preservation of Self" ${ }^{113}$ Ibid. 
traumatic events is cathartic, the transformation of such memories into visual representations of the painful events can be especially powerful." ${ }^{, 14}$ Given this, White contends that Life? or Theatre?, with its combination of text and image, served as a way for Salomon to both preserve her identity and resist Nazi oppression. ${ }^{115}$

White provides examples of her assertion that Salomon's Life? or Theatre? indicates a preservation of identity and resistance to the Nazi regime. After summarizing the pertinence of various paintings that illustrate Nazi mandates, White discusses a particularly poignant series of images that outlines Salomon's refusal to return to secondary school after the infiltration of Nazi propaganda, illustrated by paintings in which the swastika overwhelms her classroom. One scene shows a defiant Salomon who says to her father, "I won't go back to school. You can do with me what you will. I won't go back to school. I've had more than my fill." ${ }^{, 116}$ White claims that in these images, Salomon communicates the considerable amount of power "Nazi policies had on her identity." However, by depicting her refusal to return to school, Salomon provides evidence of self-preservation, in that "Salomon shows her readers resistance as a conscious choice. ${ }^{117}$

White accounts for the images devoid of text or explanation that delineate her flight to France as ones that register "Salomon's experience of leaving Germany as so painful that it is beyond words. ${ }^{, 18}$ White recalls the work of Andreas Lixl-Purcell, who describes exile as a situation in which one is forced to "engage in "the construction of a

${ }^{114}$ Ibid.
${ }^{115}$ Ibid.
${ }^{116}$ Ibid.
${ }^{117}$ Ibid.
${ }^{118}$ Ibid. 
new sense of subjectivity on which to build a new identity and a new future." 119 Therefore, White claims that leaving Germany was a pivotal moment in Salomon's existence, as she recognized that "she will not only lose her home but also any remaining grasp on her previous sense of self." ${ }^{120}$ Instead of heavily narrating the images that depict her leaving Germany, White assumes that the visuals do enough to convey the "significance of this portion of her life story," and that "what would have taken many words to express, Salomon can communicate powerfully and efficiently through a series of somber paintings." 121

White ends her essay by asserting that autobiographies have the power to make a political statement, which, through her indirect defiance of Nazi policies, Salomon does in Life? or Theatre? Finally, in her claim that autobiographies preserve lives, she equates this notion with Salomon, who, although eventually murdered by the Nazis, "made a remarkable attempt to resist their power through the use of artistic expression." While unable to resist the Nazis in a physical sense, "she wisely chose autobiography as her weapon to protect herself from their psychological force and ultimately to leave behind a permanent documentation of her life."122

In 2005, van Alphen contributed an essay to the volume Reading Charlotte Salomon entitled "Giving Voice: Charlotte Salomon and Charlotte Delbo," which discusses the link between traumatic memory and the text and images in Life? or

${ }^{119}$ Andreas Lixl-Purcell, ed., Women of Exile: German Jewish Autobiographies Since 1933 (New York: Greenwood, 1988), 6, as quoted in Leah White, "Autobiography, Visual Representations, and the Preservation of Self."

${ }^{120}$ White, "Autobiography, Visual Representations, and the Preservation of Self."

121 Ibid.

${ }^{122}$ Ibid 
Theatre ${ }^{123}$ He begins his essay by pointing out that the traumatic experiences that Salomon endured as a result of the numerous suicides in her family is a primary theme in the series. He then asserts that the text and images from Life? or Theatre? are essentially symptoms of trauma, and a "mediated way of healing the trauma."

Van Alphen summarizes the various forms of memory as outlined by Janet discussed at the beginning of this thesis: habitual, narrative, and traumatic. He also revisits the notion that, according to Janet, "trauma is a failed experience," and as a result, the memory of a traumatic event is reenacted, not narrated. ${ }^{125}$ This is problematic, as narration is a vital part of integration, and is a "controlled action, the action of telling a story." ${ }^{, 126}$ It is this element of control that van Alphen feels is missing in the case of trauma. Reenacting the traumatic event then takes the form of a drama instead of a controlled narrative, which is "thereby dependent on the time frame of the drama's scripted 'parts.", 127

Van Alphen highlights the idea that Life? or Theatre? is a narrative, told by an external narrator who is in charge, which includes drama and dialogue. However, he questions whether or not the series should be read as a life story, or as a theatrical reenactment of history. The external narrator (Salomon) reflects on this narration in a way that makes no distinction between narration and dramatic text, saying:

Since I myself needed a year to discover the significance of this strange work, many of the texts and tunes, particularly in the first paintings, elude

${ }^{123}$ van Alphen, "Giving Voice," in Reading Charlotte Salomon, 114-124. In this chapter, van Alphen also discusses the texts of Charlotte Delbo, a woman who survived Auschwitz.

${ }^{124}$ Ibid., 114.

125 Ibid., 115.

126 Ibid.

127 Ibid. 
my memory and must - like the creation as a whole, so it seems to me remain shrouded in darkness. ${ }^{128}$

Van Alphen thus claims that the text in Life? or Theatre? is comparable to a dramatic script, in which the "actors" are "bound up in the enactment of a drama which is not theirs to master.",129

Salomon clearly states in the opening pages of the series that "The author has tried - as is apparent perhaps most clearly in the Main Section - to go completely out of herself and to allow the characters to sing or speak in their own voices." ${ }^{\prime 130}$ This and Salomon's previous quote are evidence, according to van Alphen, that Salomon relinquished control over the narration, and supports further his notion that the text in Life? or Theatre? is comparable to theater, or a dramatic script. ${ }^{131}$

Although van Alphen concedes the fact that Salomon was technically in control of the narration, he nonetheless argues that her work is not a "controlled narration, but an effort to master trauma by embedding the reenactment of death, of dead family members, into a controlled action of narration." 132 According to van Alphen, the process of embedding the dramatic script into a narrative text is how Salomon attempts to master her family's tragic past, which then allows the traumatic memory to transform into one that can be integrated into her personal story, and shared with others. ${ }^{133}$

In a similar vein, van Alphen discusses the notion that narrative memory has a cultural context "whose frames evoke and enable the memory" so that it can be validated, understood, or sympathized with by others. Context and an understanding recipient are

${ }^{128}$ Salomon and Belinfante, Charlotte Salomon: Life? or Theatre?, 44; JHM: 4155-4.

${ }^{129}$ Van Alphen, "Giving Voice," 116.

${ }^{130}$ Ibid.

${ }^{131}$ Ibid.

132 Ibid.

${ }^{133}$ Ibid. 
missing in traumatic memory. ${ }^{134}$ A method of communication is necessary, and relies on a listener. Van Alphen asserts that when Salomon seemingly "relinquishes" her control over the narration, she in turn becomes the listener, the provider of context for the actors in her drama. Only then are her traumatic memories embedded, or played out, narrated, and worked through. ${ }^{135}$

The context provided by Salomon involves an "implicit 'discussion' of the intimate relationship between death and life. ${ }^{\prime 136}$ For example, in the first scene of the series, Salomon's aunt, Charlotte Grunwald, walks through the streets of Berlin before finally drowning herself in Lake Schlachten (Figure 7). In the following images, Grunwald's sister, Salomon's mother, announces that she wants to become a nurse in order to save the lives of injured soldiers during World War I (Figure 8). This monumental decision coincides with Salomon's later reaction to her grandmother's suicide and her grandfather's accusation that she will die in the same manner, in which she decides to embark upon a project that is "wildly eccentric." Van Alphen writes that these and similar situations that explore the relationship between life, death, and art give structure to, or contextualize, Salomon's life and life work. ${ }^{137}$

These frameworks provide a site where "Charlotte Kann" can access creativity and therefore work through traumatic experiences on Salomon's behalf. Van Alphen gives examples of this access to creativity and its purpose, which is achieved through Salomon's interaction with Wolfsohn, who informs her of his belief that "the frontier

\footnotetext{
${ }^{134}$ Ibid., 116-117.

135 Ibid., 117, 120.

${ }^{136}$ Ibid., 120.

${ }^{137}$ Ibid. See also Salomon and Belinfante, Charlotte Salomon: Life? or Theatre?, 47, 49; JHM: 4156 \& 4158, respectively.
} 
between death and life is indispensable for the emergence of art." ${ }^{, 138}$ Van Alphen then outlines Salomon's emphasis on the story of Orpheus, who went to the underworld to rescue his wife Eurydice. Wolfsohn's characterization of the myth created a framework for her to "tell her story [and how] she will resist and transgress, in order to make the work for her need: the overcoming of trauma." 139

Numerous pages of Life? or Theatre? are dedicated to Wolfsohn's ruminations on and comparisons with Orpheus. For example, one particular string of paintings delineate Wolfsohn's impression that Eurydice eventually loses her status as the primary meaning of Orpheus' descent. Instead, the goal of his descent evolves into a desire to seduce the god of the underworld with his art and music; Eurydice is the precondition of his descent, and her love "supports and sustains his creative pursuit." ${ }^{140}$ Likewise, Wolfsohn's love for Lindberg and Salomon serves as “nourishing mediators in [Wolfsohn's] creative pursuit." ${ }^{141}$ However, that Salomon and Lindberg both have their own creative interests serves as Salomon's way of transgressing Wolfsohn's authority. Salomon's incorporation of the Orpheus myth monotonously belabored by Wolfsohn thereby serves as a "mental frame," within which she can express traumatic events from her life. ${ }^{142}$

Finally, the communicative situation between external narrator Salomon and viewers makes creating contextual frameworks possible for "Charlotte Kann" to reenact the numerous suicides in her family without such painful associations. According to van

\footnotetext{
${ }^{138}$ Ibid., 120-121. Van Alphen says Salomon's access to art via Wolfsohn is "strongly gendered." For more on this topic, see van Alphen, Caught by History, 65-92.

${ }^{139}$ Ibid., 121.

${ }^{140}$ Ibid., 122.

${ }^{141}$ Ibid., 123.

142 Ibid. Van Alphen contends that Salomon also uses Michelangelo's work to embed the concept of life, death, and creativity.
} 
Alphen, Salomon, through her formation of mental frames and subsequent narration of events, embeds her family's tragedies into an overall narrative, essentially integrating them into a framework where she can make sense of them. ${ }^{143}$

Pollock contributed an essay to Reading Charlotte Salomon as well, "Theater of Memory: Trauma and Cure in Charlotte Salomon's Modernist Fairytale.” To begin her essay, Pollock theorizes the time frame within which Salomon worked as "Before Auschwitz," which takes its cue from Theodor Adorno's term “After Auschwitz." Adorno's term communicates the idea that human death has been changed by the "inhuman manner of destruction in the concentration camps." ${ }^{\text {144 }}$ Adorno says that since Auschwitz, people "die differently": "they survive death," because what took place in concentration camps was worse than death. ${ }^{145}$ However, part of Pollock's argument in this essay is that the decade that led up to the unprecedented systematic elimination of Jews, 1933-1942, is indicative of a "catastrophic rupture" in any historical narrative. The period of time in which Nazi mandates affected everyday life for Jewish citizens and eventually led to the gas chambers demands a "new theoretical/historical space," which Pollock calls "Before Auschwitz." ${ }^{146}$ It is within this space that Life? or Theatre? was created, and that also serves as the backdrop to Salomon's story.

Pollock discusses Life? or Theatre? as a visual manifestation of Walter Benjamin's concept of a life-map, described as a way to set out "the sphere of life - bios

143 Ibid., 125.

144 Pollock, "Theatre of Memory," 38.

145 Theodor Adorno, "Meditations on Metaphysics: I. After Auschwitz," Negative Dialectics, trans. E. B. Ashton (New York: Continuum, 1973), 362 as quoted in Pollock, "Theatre of Memory," 38.

${ }^{146}$ Pollock, Theater of Memory," 40, 50. 
- graphically on a map," as opposed to fragmented, linear life-stories. ${ }^{147}$ Salomon's space for her life-map, or "theater of memory" evidenced in Life? or Theatre?, reflects on the memory of what Pollock considers the suspended time "Before Auschwitz." In this way, Life? or Theatre? serves as a space where the era "Before Auschwitz" can be examined, which Pollock undertakes through her use of examples from the series that describe various Nazi policies. ${ }^{148}$

Likewise, Life? or Theatre? as a theater of memory served as a space where Salomon could recreate memories and explore "the lives, loves, and deaths of several women." ${ }^{149}$ The series is a space where Salomon can investigate the life, death, and the turmoil experienced by her aunt, mother, and grandmother in deciding between these two options. Life? or Theatre? is also a space where Salomon can defeat these deaths by giving them a "concrete image," as opposed to their looming in her memory as a "threatening fantasm." 150

Lastly, Pollock considers the notion that Life? or Theatre? served as a space where Salomon could work through the trauma she experienced in her childhood and adult life. In this portion of the essay, Pollock briefly outlines Janet's theory of traumatic

${ }^{147}$ Walter Benjamin, "A Berlin Chronicle," in One-Way Street, trans. Edmund Jephcott and Kingsley Shorter (London: NLB, 1979), 295, as quoted in Pollock, "Theater of Memory," 55. Pollock revisits her idea of Life? or Theatre? as a life-map in other essays, including "Life-Mapping: Or, Walter Benjamin and Charlotte Salomon Never Met," in Conceptual Odysseys: Passages to Cultural Analysis, edited by Griselda Pollock (New York: I. B. Tauris \& Co. Ltd., 2007), 63-88; "What Does A Woman Want?: Art Investigating Death in Charlotte Salomon's Leben? oder Theater?" Art History 30, no. 3 (2007): 383-405; and "Mapping the 'bio' in Two Graphic Systems with Gender in Mind: Reading Van Gogh through Charlotte Salomon and Vice Versa," in Biographies and Space: Placing the Subject and Architecture, edited by Dana Arnold and Joanna R Sofaer (New York: Routledge, 2008), 115-139.

${ }^{148}$ Pollock, "Theater of Memory," 50-58.

${ }^{149}$ Ibid., 56-57.

${ }^{150}$ Ibid., 57-59. 
memory, the importance of assigning narrative to horrific mental images, and making them part of her life story. Pollock describes Life? or Theatre? in this way:

An artistic staging not of the real, but of invented memory and imagined subjectivities, that allowed the traumas of its authoring subject and her cosubjects... a means to pass into signification, to inhabit a loosely narrative form, to be structured by a logic, an order, an arrangement that places lives within frames and sequences, scenes governed by meaning-securing statements. $^{151}$

This argument, similar to van Alphen's, accounts for a space within Life? or Theatre? where context, narrative, and image combine and illustrate the assimilation of traumatic memories into adjusted or newly formed mental frameworks.

The work of White, van Alphen, and Pollock collectively reinforces the notion that Salomon's traumatic experiences depicted in Life? or Theatre? were somehow worked through by the contextualization and narration of past events. White's essay elucidates the argument that Salomon visualized mental schemes that allowed her to identify with, yet resist, Nazi oppression. According to van Alphen, the establishment of context and a narration of traumatic events provided for Salomon a method of embedding and subsequently mastering the deaths of her aunt, mother, and grandmother. Pollock argues that Salomon's theater of memory allowed a separate space for her to pass traumatic memories into signification. In contrast, my argument is that, despite Salomon's attempts to work through her trauma and pass these memories into signification, her efforts were incomplete. Although White, Pollock, and van Alphen's arguments, which concentrate on the progress Salomon made in her endeavor to contextualize and narrate traumatic events, are directly relevant to my understanding of

151 Ibid., 68. 
the series, evidence of the dialectic of trauma abounds in Life? or Theatre?, leaving viewers to question how successful these efforts were. 
THE DIALECTIC OF TRAUMA:

READING INTEGRATION, INTRUSION, AND CONSTRICTION

What purpose, therefore, did Life? or Theatre? serve? To answer this question, I begin this section by discussing how Salomon's Life? or Theatre? functioned as a healing tool in her effort to externalize and make sense of traumatic experiences. The paintings examined here are visual evidence of what Herman describes as film stills from a silent movie. Salomon's incorporation of narration and music directly correlates to Herman's suggestion that in order to integrate these traumatic memories, one must "provide the music and the words," which is exactly what Salomon (via CS) did in Life? or Theatre ${ }^{152}$ White, van Alphen, and Pollock each describe this work as a process of reenactment, contextualization, and narration, all of which allow these recollections an opportunity to pass into signification. However, despite her efforts to integrate her traumatic memories into a personal narrative, by examining the collection of images further it becomes clear that, in many ways, Salomon's attempt to heal falls short. In addition to Salomon's endeavor to integrate traumatic experiences, viewers are confronted with evidence of her oscillation between intrusive and constrictive symptoms, or the dialectic of trauma. In the final sections of this thesis, I focus on various structural characteristics and images in order to consider Salomon's series as a space where she could visualize these competing symptoms, which perhaps denotes the failure on

${ }^{152}$ Herman, Trauma and Recovery, 175. 
Salomon's part to complete the task of contextualizing and narrating traumatic events from her past.

\section{INTEGRATION}

The notion that Life? or Theatre? provided Salomon a platform where she could create context for her traumatic experiences is best evidenced by the incorporation of music and text alongside her visual representations. Salomon's relationship with Lindberg clearly affected her choice to structure Life? or Theatre? as a dramatic performance complete with a musical soundtrack. Upon entering Salomon's life, Lindberg took on the role of mother, and gave Salomon the attention and support that was lacking in her relationship with her father. Van der Kolk says that this caregiver relationship affects how victims respond to trauma: "as long as they feel taken care of by someone stronger than themselves, psychological and biological systems seem to be protected against becoming overwhelmed." ${ }^{153}$ Lindberg, as the older and wiser adult, was for Salomon the person stronger than herself, and thereby naturally influenced how Salomon reacted to the chaos in their lives incited by the Nazi party.

From 1933 until Salomon left for France in 1939, her adolescent years revolved in part around Lindberg, Wolfsohn, and Kulturbund activities; theater and music served as a perpetual backdrop to Salomon's daily life. Likewise, Salomon was privy to the fight for the right to engage in these endeavors. Herman discusses the importance of structuring context within which traumatic events occurred. Reclaiming this history is vital, as it serves to "re-create the flow of the patient's life and restore a sense of continuity with the

${ }^{153}$ Van der Kolk, Traumatic Stress, 303. 
past." 154 Therefore it seems logical that when Salomon began Life? or Theatre?, looking back on these formative years would influence her to create a work that evoked both theater and music.

Specifically, text as a contextual tool supports the idea that attaching a narrative to her reenactments in Life? or Theatre? allowed Salomon to create and identify with a mental framework in order to make sense of what she could not previously understand. In her book Trauma: Explorations in Memory, Cathy Caruth writes that trauma is "the force of an experience that is not yet fully owned," and "the confrontation with an event that, in its unexpectedness or horror, cannot be placed within the schemes of prior knowledge." 155 With this in mind, it is plausible to contend that for Salomon, her grandfather's revelation that numerous family members committed suicide was a primary force that ruptured existing mental schemes. As van Alphen wrote, "she made her life work... to repudiate the family fate of suicide," such that "her work is a way of fighting history. $" 156$ In order to process these ruptured mental schemes and make sense of them, Salomon felt the need to revisit many details of her life and restructure them, armed with the knowledge of her predicament: that she could follow in her aunt, mother, and grandmother's footsteps. The narrative in Life? or Theatre? could therefore be seen as a way for Salomon to include, as Herman says, "not only the event itself but also the survivor's response to it and the responses of the important people in her life." ${ }^{, 157}$

Salomon reenacts moments from her past that envelope this newly acquired, traumatizing information. From the beginning of Life? or Theatre?, Salomon paints

\footnotetext{
${ }^{154}$ Herman, Trauma and Recovery, 176.

${ }^{155}$ Caruth, Trauma: Explorations in Memory, 151, 153.

${ }^{156}$ Van Alphen, Caught by History, 89.

${ }^{157}$ Herman, Trauma and Recovery, 177.
} 
scenes, complete with complementary narrative, that allow her to, as van Alphen says, master the death of her family members. For example, after the opening scene of the Prelude, in which Salomon's aunt Charlotte drowned herself in Lake Schlachten, she painted an image with a newspaper excerpt that describes her death (Figure 9):

Suicide of eighteen-year-old! Charlotte seeks death in Lake Schlachten! Last night a young girl drowned herself in Lake Schlachten. The body was recovered and was identified this morning at the morgue by her father. We extend our deepest sympathy to her parents and trust they will find consolation in their older daughter. ${ }^{158}$

In the top part of the image, bathed in blue, Salomon depicts her dead aunt at the morgue, while Dr. Grunwald leans over to identify her. The center of the picture contains the newspaper excerpt while the bottom illustrates the Grunwald family grieving over the loss of their daughter/sister.

Likewise, Salomon paints the onset of her mother's melancholia in JHM: 4176

from the Prelude (Figure 10). The overlay for the painting is narrated like this:

Quite inexplicably, Franziska suddenly ceases to find pleasure in anything... she plays the piano, she helps her husband, she continues to keep entire dinner parties entertained with her high spirits, and accompanies Charlotte's gym lessons on the piano. But none of it gives her pleasure. She is in despair. Her expression has completely changed. She speaks only of death. Albert tells her he needs her, and that Charlotte needs her mother too: she was so young, just eight years old, but all in vain. Franziska had lost all desire to go on living, and one night she got out of bed and from her husband's medical kit took a strong dose of opium, swallowed it and returned to bed. ${ }^{159}$

This dark painting is a conflation of the activities mentioned in the overlay. Across the top in small vignettes, Mrs. Salomon plays the piano, hosts a dinner party, and provides musical accompaniment for Salomon's gym lesson. The middle row of the painting depicts Mr. Salomon expressing to his wife the valuable role she plays in their family.

${ }^{158}$ Salomon and Belinfante, Charlotte Salomon: Life? or Theatre?, 48; JHM: 4157.

159 Ibid., 67; JHM: 4176. 
Finally, the bottom row of the image illustrates Mrs. Salomon's suicide attempt. A few images later, Salomon depicts her mother in a heap on the ground after having plummeted from her bedroom window (Figure 11). To the tune of Weber's "We Twine for thee the Maiden's Wreath," the overlay narrates the scene like this: "Franziska died immediately, the apartment being on the third floor. There is nothing more to be done about the tragedy." 160

Later in the series, Salomon sits with her grandmother while she rests in between suicide attempts. In an effort to dissuade Mrs. Knarre from ending her life, Salomon spends a great deal of time trying to cheer her up by singing, among other songs, Schiller's "Ode to Joy," and reminding her grandmother of her days as a poet. In JHM: 4875 (Figure 12), Salomon painted the end of a conversation with her grandmother, trying to create "meaning in a crisis of meaninglessness." "161 The painting consists of eleven versions of Salomon's profile, while the text winds around her floating heads. It is narrated in part by Salomon saying to her grandmother:

If you think about it, you can look back on a wonderful, full life. Apart from anything else, you've found a great deal of satisfaction, and you have succeeded in expressing in poems many things that have been denied to others. $^{162}$

Salomon implores her grandmother not to commit suicide, but instead concentrate on her writing talents. Despite her efforts, Salomon is unable to convince Mrs. Grunwald to live and subsequently witnesses her grandmother's jump from her bedroom window.

Following Pollock, Life? or Theatre? allowed Salomon a space where she could restage parts of her life, taking into account her fear that she would inevitably commit

\footnotetext{
${ }^{160}$ Ibid., 72; JHM: 4181.

161 Austin, "The Endurance of Ash," 113.

${ }^{162}$ Salomon and Belinfante, Charlotte Salomon: Life? or Theatre?, 762; JHM: 4875.
} 
suicide. This theater of memory was a place where she could act out and recontextualize events that were not previously associated with such sinister overtones. By injecting the reenactment of her aunt and mother's death with the unfortunate truth, Salomon is able to adjust or reconstruct her mental schemata, provide traumatic memories with narrative, and potentially integrate them into her personal story.

Salomon also creates frameworks related to the onset of Nazi oppression and its effects on her family. Salomon introduces viewers to the power of Nazi Germany in Act Two of the Prelude (Figure 13). Faceless Nazi soldiers march through the streets of Berlin with an air of pomp and circumstance on January 30, 1933, the day Hitler claimed the title of Chancellor in Germany. Salomon used brown to portray the uniforms and dabs of red to link the soldiers to the Nazi flag. The accompanying text explains the action to readers:

The swastika - a symbol of bright hope - the day for freedom and for bread now dawns - Just at this time, many Jews - who, with all their often undesirable efficiency, are perhaps a pushy and insistent race, happened to be occupying government and other senior positions. After the Nazi takeover of power they were all dismissed without notice. Here you see how this affected a number of different souls that were both human and Jewish! ${ }^{163}$

In her essay "A Life Before Auschwitz," Monica Bohm-Duchen points out that in quoting this Nazi rhetoric, Salomon mocks and subverts Jewish stereotypes. BohmDuchen also argues that this mockery identifies for Salomon an uneasy relationship with the Jewish race. ${ }^{164}$ As mentioned earlier, Salomon and her family did not practice Judaism in their home until Lindberg married Dr. Salomon. Therefore, it is conceivable

163 Ibid.,192; JHM: 4304.

${ }^{164}$ Monica Bohm-Duchen, "Life After Auschwitz," in Reading Charlotte Salomon, 23. 
that Salomon would reluctantly identify herself as a full-fledged member of the Jewish race.

The next page from Life? or Theatre? is a direct reference to the Nazi-enforced Jewish boycott of April 1, 1933 (Figure 14). In the foreground, a small crowd stands in a circle around a gigantic sign that says:

Der Sturmer, organ of popular enlightenment. The Jew has made only money from your blood. The Jewish bosses financed the World War. The Jew has deceived and betrayed you, so - German men and women. Take your revenge!!! Once Jewish blood spurts from the knife, you'll have by far a better life. Hunt the swine until he sweats and smash his windowpanes to bits. April 1, 1933 - Boycott the Jews! Whoever buys from any Jew, himself a filthy swine is too. ${ }^{165}$

The image of this circular group is conflated with parading Nazi soldiers, who, in their brown uniforms march in a diagonal trajectory past the forlorn sign readers, the swastika flag leading the way. Salomon activated this image even further by illustrating the boycott and smashing of windowpanes on the other side of the Nazi march. Jewish surnames are given to the stores being boycotted and destroyed, while many of the perpetrators are painted with raised hands. Perhaps they angrily shake their fists at the Jewish shopkeepers, or maybe their arms are raised in celebration. While the violence in the background is alarming, with the Nazi soldiers passing by and ignoring the angry mob, the large sign dominates the visual field and commands the attention of the viewer. ${ }^{166}$

Later in the Main part, Salomon begins a new section entitled "And Time Marches On." At this point in the series, Salomon painted text directly onto the sheets of paper. The first sheet depicts a press release, telling the story of the German diplomat's

${ }^{165}$ Salomon and Belinfante, Charlotte Salomon: Life? or Theatre?, 193; JHM: 4305. Der Sturmer was an anti-Semitic publication. Bohm-Duchen, "Life After Auschwitz," 23. ${ }^{166}$ White, "Autobiography, Visual Representations, and the Preservation of Self." 
assassination that led to the Kristallnacht pogrom (Figure 15). The announcement dominates the center of the painting and is surrounded by throngs of blue-tinged, abstracted individuals, with a loosely rendered Nazi flag on the left side. The text in the press release reads as follows:

November 9, 1938. Der Angriff. Cowardly Sneak Murder by Jew Abroad. Grunspan, a Jew, sneaks into the German Consulate and shoots German diplomat to death. Deeply shocked, the entire German nation stands beside the bier of its son. This is the latest outrage to be perpetrated by Judea's might! The German people will have their revenge! German men and women: our forbearance toward the criminal Jewish world-power has come to an end. ${ }^{167}$

On the next page, Salomon illustrates the single snapshot image, or film still, in her memory of the harrowing night on which Kristallnacht occurred (Figure 16). The caption in the top left corner exclaims, "Perish Judea! Grab what you can!" 168 German citizens coarse through the streets in packs while the buildings in the background hang Nazi flags from their windows. In the bottom right corner, two soldiers are forcing three prisoners along the page; in the opposite corner a man trudges along the street, possessions under his arm.

In her essay “Autobiography, Visual Representations, and the Preservation of Self," White interprets these images as manifestations of horrific memories, but also as a way of foreshadowing future violence. ${ }^{169}$ With this idea in mind, I argue that these images are further reclamations of Salomon's past; they are, as van Alphen might contend, a contextual tool of foreshadowing that allows the viewers comprehension of future events. Herman asserts that these explanations are vital and that these explorations provide "a context within which the particular meaning of the trauma can be

${ }^{167}$ Salomon and Belinfante, Charlotte Salomon: Life? or Theatre?, 647; JHM: 4761.

${ }^{168}$ Ibid., 648; JHM: 4762.

${ }^{169}$ White, "Autobiography, Visual Representations, and the Preservation of Self." 
understood." ${ }^{170}$ Therefore, while this image visualizes a traumatic memory and refers to future violence, its more important function is to provide an overarching backdrop within which Salomon can then frame how these oppressive Nazi tactics affected her personally.

Subsequent images detail Dr. Salomon's loss of employment in the Berlin Hospital, as well as Lindberg's on-stage persecution (Figures $17 \& 18$ ). In the top portion of JHM: 4306 (Figure 17), Dr. Salomon gives a lecture to his colleagues while standing over a cadaver, an image reminiscent of Rembrandt's Anatomy Lesson of Dr. Tulp. The top image has a defiant red "X" over it, denoting the fact that Dr. Salomon is no longer responsible for such lessons. In the bottom part of the image, Salomon portrays a miserable Dr. Salomon with his head in his hands; weary red eyes convey an exhausted mind. Likewise, in JHM: 4308 (Figure 18), Lindberg performs on stage alongside "Dr. Singsong," while the Nazi audience members shout at them "Out - get out - out - get out."171

Salomon later portrays Dr. Singsong going to Nazi headquarters to implore the Minister of Propaganda (presumably Joseph Goebbles) for permission to form the Kulturbund (Figure 19). In this painting, Singsong stands in front of a dominating building with the Nazi flag waving over the door. In the accompanying overlay, the tiny figure of Singsong says, "I must say it's not so pleasant to have to go to these Nazis - but I'll take it upon myself." 172

Perhaps White would interpret these images as examples in which identity was tied to Nazis, or, in the case of Singer, a way of subverting Nazi power. Dr. Salomon falls

\footnotetext{
${ }^{170}$ Herman, Trauma and Recovery, 176.

${ }^{171}$ Salomon and Belinfante, Charlotte Salomon: Life? or Theatre?, 194, 196; JHM: 4306 \& 4308, respectively.

172 Ibid., 200; JHM: 4312.
} 
victim to the Nazi mandate that expelled him from his job, while Lindberg faces a hostile crowd, simply because they are Jewish. However, Singer's meeting with the Minister of Propaganda is a defiant act of bravery that is eventually successful; he was allowed to create the Kulturbund. Considering Salomon was able to embody each of her characters during the series, she is, in effect, on the receiving end of Dr. Salomon's loss and Lindberg's on-stage persecution, yet is also responsible for Dr. Singer's triumph in gaining permission to establish the Kulturbund. These images and narration contextualize for Salomon various events from her past and the way her family and those close to them fell victim to, or triumphed over, Nazi oppression in the era Before Auschwitz.

Life? or Theatre? was for Salomon, as Pollock would say, a theater of memory, where she visualized characters who reenacted parts of her life that she considered improperly remembered due to her lack of accurate information. Once her grandfather provided her with the missing pieces of her family's history, Salomon reconstructed scenes of her aunt, mother, and grandmother's death in order to, as van Alphen says, embed and master the story of their deaths, allowing it the opportunity to pass into signification. Similarly, Salomon entrenches further her family's predicament by visualizing the impact that Nazi mandates had on her and those close to her. In these reenactments, Salomon is given the opportunity to both acknowledge and subvert the power of the Nazis. In each of the images discussed above, her use of image, text and music combine to meet the ultimate goal, which is to "put the story, including its imagery, into words," and subsequently assimilate these memories into her personal narrative. ${ }^{173}$

${ }^{173}$ Herman, Trauma and Recovery, 177. 
Despite Salomon's efforts to reconstruct memories and attach them to narrative and music, characteristics consistent with the dialectic of trauma are evident throughout the series. In the next two sections, I want to outline features of Life? or Theatre? that are consistent with Herman's definition of intrusion and constriction. In doing so, I consider that perhaps Salomon's efforts to overcome, or master, her traumatic past fall short.

\section{INTRUSION}

The primary characteristic of intrusion is the persistent bombardment of traumatic memories, corresponding with Herman's claim that "trauma arrests the course of normal development by its repetitive intrusion into the survivor's life." 174 Likewise, Janet believed that the traumatized person "remains confronted by a difficult situation, one in which he has not been able to play a satisfactory part, one to which his adaptation has been imperfect, so that he continues to make efforts at adaptation." ${ }^{175}$ Furthermore, Richard Scaer asserts that "the intrusive thoughts, flashbacks, and nightmares associated with this unique process suggest that the past danger remains present and imminent in memory and awareness." ${ }^{176}$ With these ideas in mind, perhaps Salomon painted subjects numerous times not only because these traumatic memories constantly, if involuntarily, bombarded her, but also recording this bombardment provided her with an opportunity to justify, or more fully comprehend, the sequence of events. Intrusive, traumatic memories appear frequently throughout the series, which may indicate Salomon's desire to adjust or rationalize her understanding of the tragedies that transpired.

\footnotetext{
${ }^{174}$ Herman, Trauma and Recovery, 37.

175 Janet, Psychological Healing, 603, as quoted in Trauma and Recovery, 41.

${ }^{176}$ Robert Scaer, The Trauma Spectrum: Hidden Wounds and Human Resiliency (New York: Norton, 2005), 59.
} 
Mentioned in her biography above, Salomon's father was rounded up during Kristallnacht and taken to the Sachsenhausen concentration camp. Near the end of the Main Section of the series, Salomon visualizes what she imagines Dr. Salomon suffered while imprisoned (Figures $20 \& 21$ ). In the first image, her father is bent over, holds some kind of tool in his hand, and works the soil Salomon has painted in front of him. A Nazi soldier stands behind him and accuses him of laziness; the caption reads, "Meanwhile Dr. Kann, former professor, is forced to do heavy manual labor. Camp guard: 'You have to work here, there'll be no loafing." ${ }^{\prime 177}$ In the next image, Dr. Salomon is kneeling on the ground while the prison guard towers over him and asserts: "You've done enough loafing in your lives." $" 178$ These images come from an event Salomon did not experience first hand, yet through her use of swiftly outlined figures, and harsh accompanying text, she manages to convey fear and apprehension.

Salomon dedicates many sheets to the torment endured by Lindberg to have Dr. Salomon released. One particularly poignant picture outlines Lindberg's tenacity, while a second image pictures the successful result of her dangerous labor (Figures $22 \& 23$ ). In JHM: 4769 (Figure 22), Salomon painted numerous images of Lindberg, which perhaps indicates the many conversations and meetings she engaged in when trying to persuade the proper authorities to release Dr. Salomon. Salomon narrates the scene like this: "There must be a way to get him released. I need a visa, and I'll get it. What's the use of my charm if I can't win over anyone I like?"179 JHM: 4801 (Figure 23) signifies Dr. Salomon's liberation, resulting from his wife's endeavors. Salomon has this to say about

${ }^{177}$ Salomon and Belinfante, Charlotte Salomon: Life? or Theatre, 684; JHM: 4798.

${ }^{178}$ Ibid., 685; JHM: 4799.

${ }^{179}$ Ibid., 655; JHM: 4769. 
his release: “And indeed Paulinka's great efforts do succeed in getting Albert released. Camp intendant: 'You may go. You're discharged."’180

Again, Salomon painted scenes that are merely assumptions of what her father and Lindberg experienced. Even though she was not incarcerated with her father in Sachsenhausen, she still needed to understand the horrors of his internment. Likewise, Salomon may have wanted to feel as involved as possible in Lindberg's rescue mission. As mentioned above, that Salomon was not a specific character in her own operetta allowed her the freedom to embody other characters; she shares in her father's pain and Lindberg's fear that her husband may never return. Her numerous visual representations of this event can be interpreted as an opportunity for Salomon to make her father and Lindberg's traumatic experience her own, and place it within her own personal narrative. However, this was a particularly traumatic memory for Salomon, as it was the catalyst for her exile in France that forced her to leave her family, friends, and Berlin for the rest of her life. ${ }^{181}$ Therefore, it is unsurprising that this memory would consistently haunt her, thus manifesting itself as a topic that she would return to many times in her life work.

After reaching France, Salomon witnessed the psychological demise of her grandmother, apparently the result of war and Nazi persecution. In JHM: 4846 (Figure 24), Salomon depicts Mrs. Grunwald attempting suicide by hanging herself. Her grandmother stands in a bathroom between the toilet and the bathtub, fitting a noose around her neck. Salomon narrates the event in this way:

Old Mrs. Knarre tries to hang herself in the bathroom. The awful pain that has pursued her throughout her life but had been kept somewhat in abeyance seems to have resurfaced into full consciousness as a result of

\footnotetext{
${ }^{180}$ Ibid., 687; JHM: 4801.

${ }^{181}$ Schultz and Timms, "Charlotte Salomon: Images, Dialogues and Silences,” 275.
} 
the raging war, and she feels her sharp intellect and her self-control, which had made her life worth living, breaking up against a greater force. Fear of the onset of madness drives her to this decision. ${ }^{182}$

Mrs. Grunwald's suicide attempt is unsuccessful this time, but she soon loses her battle with madness.

In the midst of Salomon's depictions of Mrs. Grunwald's attempt to take her own life, Salomon's grandfather shocks her with a story about the prevalence of suicide in their family (Figure 25). In this image, Dr. Grunwald tells Salomon why he seems to be so nonchalant about his wife's endeavor to end her life. Her grandfather's body takes up the entire page, and Salomon applied the narration of this scene around him, which says:

Your mother tried it with poison, then she threw herself out the window. Your Aunt Charlotte drowned herself, but the worst case was Grandma's mother. For eight years she tried every day to escape the care of two nurses in order to take her life. ${ }^{183}$

The next five images detail the history of suicide in the Salomon family. On each sheet Salomon depicted a varying number of rows containing numerous versions of her grandfather's talking head, while the text snakes around each individual face. In JHM: 4865 (Figure 26), Salomon illustrates the end of her grandfather's story, where he sheds light on the concern for her own welfare, "Now you and your future remain her [Mrs. Grunwald] sole concern. We arranged for you to visit us every year, and you owe it entirely to her [Mrs. Grunwald] that you could come and lead such a pleasant life with us

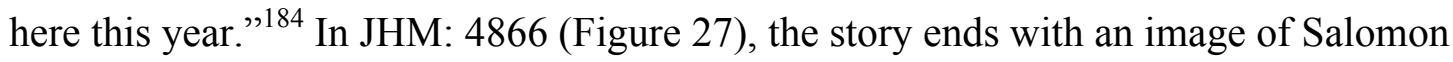
sitting on a bed facing her grandfather; the narration winds around her body. The image is accompanied by Salomon's shocked response: "Nobody had ever told Charlotte how

182 Salomon and Belinfante, Charlotte Salomon: Life? or Theatre, 733; JHM: 4846.

${ }^{183}$ Ibid., 747; JHM: 4860.

${ }^{184}$ Ibid., 752; JHM: 4865. 
some of her family had lost their lives. Charlotte: 'I knew nothing of all that. I always thought my mother had flu and died of flu." ${ }^{\prime 185}$

After listening to her grandfather's shocking revelation, Salomon tries with increasing fervor to dissuade her grandmother from killing herself. Subsequently, more than forty paintings depict Salomon's quest to keep her grandmother alive. Some of these paintings illustrate a conversation between the two women, while others are not accompanied by narration or dialogue, perhaps because words could not fully encompass the horror of what Salomon knows will come to pass. Salomon eventually witnesses her grandmother's death; she jumped from a window like Salomon's mother. In JHM: 4900v (Figure 28), her grandmother is lying on the ground outside the hotel in a heap, reminiscent of the way her mother's body was imagined in the Prologue. One leg protrudes into the air, while blood amasses around her head. Salomon leans over her body. The narration is painted on top of Salomon's body, and reads simply, "May you never forget that I believe in you." 186

Details of her grandmother's death and her grandfather's horrific revelation were a constant barrage on Salomon's memory, as are evidenced by the number of paintings from Life? or Theatre? that illustrate these events. These loosely rendered paintings are manifestations of what psychiatrist Robert J. Lifton would consider persistent, indelible images or flashbacks. ${ }^{187}$ Perhaps Salomon painted this event numerous times so that she could, as Janet might suggest, adjust the part she played in the situation or her adaptation

\footnotetext{
${ }^{185}$ Ibid., 753; JHM: 4866.

${ }^{186}$ Ibid., 788; JHM: 4900v. This line comes from an earlier dialogue between Wolfsohn and Salomon. Before she leaves for France, Wolfsohn tells her the same thing. ${ }^{187}$ Robert J. Lifton, "The Concept of the Survivor," in Survivors, Victims, and Perpetrators: Essays on the Nazi Holocaust, edited by J. E. Dimsdale (New York: Hemisphere, 1980), 113-126, as quoted in Herman, Trauma and Recovery, 38.
} 
to the outcome. ${ }^{188}$ While some of these images do contain a narrative or dialogue, which could imply that the memory was assimilated within her personal story, nonetheless, the visual evidence betrays a persistent onslaught of memories in which Salomon, try as she might, could not change the outcome.

Similarly, Salomon consistently questions her mental state throughout Life? or Theatre? Salomon frequently considers whether or not she is capable of continuing on with life, or if she should follow her aunt, mother, and grandmother's lead by committing suicide. For example, Salomon imagines that her parents worry about the possibility that she might follow in her aunt and mother's footsteps. In JHM: 4323 (Figure 29), when discussing Salomon's schooling, she broods in the top portion of the picture, while Dr. Salomon and Lindberg discuss her state of mind in the bottom portion: "Albert: 'I'm worried about her. I needn't tell you why.' Paulinka: 'That's just Weltschmerz, it'll pass, my dear. There's nothing to be worried about. I was just the same at her age."”189 Similarly, Lindberg expresses concern over her stepdaughter after Dr. Salomon is interned at Sachsenhausen (Figure 30). Salomon leaves their apartment to look for Wolfsohn, but Lindberg runs to catch up with her, having assumed the worst:

Paulinka has suddenly remembered Charlotte's unstable family on her mother's side, and a sense of dread - Charlotte might do herself an injury - makes her go out onto the street and run after her because she has seen her from the window. ${ }^{190}$

Salomon elucidates the notion that her parents were both extremely concerned with her response to life's troubles, and she imagines it was a topic of conversation revisited many times throughout the course of her adolescent years.

188 Janet, Psychological Healing, 603, as quoted in Herman, Trauma and Recovery, 41.

189 Salomon \& Belinfante, Charlotte Salomon: Life? or Theatre?, 211; JHM: 4323.

${ }^{190}$ Ibid., 673; JHM: 4787. 
Furthermore, Salomon consistently depicts personal expressions of anger, dread, and psychological instability throughout Life? or Theatre? For example, in JHM: 4790 (Figure 31), after her father has been imprisoned, Salomon stands alone with her hands by her mouth, exclaiming, "I can't take this life any more. I can't take these times anymore. ${ }^{\prime 191}$ Another set of images detail the way she responds to hurt feelings, resulting from an exchange with Wolfsohn. In JHM: 4716 (Figure 32), Salomon stands in front of a window, the scene narrated in this way: "She is filled with grief mingled with rage. Charlotte: 'I'll start by throwing money out of the window!'” In the following image, however, Salomon abruptly asserts, “In fact I wouldn't mind throwing myself out too"192 (Figure 33). In JHM: 4907 (Figure 34), after having learned the truth of her mother's death, a loosely rendered, profiled Salomon sits in front of a window with one hand pressed to her forehead. The background consists of wide brush strokes of orange and yellow, evocative of a flame burning out of control. ${ }^{193}$ The narration that accompanies this image says, "Dear God, please don't let me go mad."194 White describes this image as a "painful representation of Salomon's burning anxiety concerning her fate." 195

Conversely, Salomon does illustrate bursts of optimism. For example, in JHM: 4877 (Figure 35) she rejects her grandmother's discontented ramblings and, standing in a kitchen facing the counter, says to herself, "How beautiful life is, I believe in life! I will

${ }^{191}$ Ibid., 676; JHM: 4790.

192 Ibid,. 602-603; JHM: 4716 \& 4717, respectively.

${ }^{193}$ White, "Autobiography as Performative Identity Construction," 85.

194 Salomon and Belinfante, Charlotte Salomon: Life? or Theatre?, 795; JHM: 4907.

${ }^{195}$ White, "Autobiography as Performative Identity Construction," 85. 
live for them all!" ${ }^{196}$ Also, in JHM: 4919v (Figure 36), an image produced after her return from Gurs, Salomon looks out a window and shouts, "God, oh God, how beautiful!!"197 By including images like these, relative to the number of paintings that depict her consideration of suicide, Salomon provided viewers with glimpses into her internal battle between the morose and the joyous, the overwhelming decision between living or succumbing to fate.

Salomon's numerous visual representations of her contemplation of suicide and psychological instability indicate that these thoughts were a constant barrage on her consciousness. Salomon did not commit suicide, and instead decided to create Life? or Theatre? However, the consistent appearance of suicidal ruminations throughout the series signifies the intrusive quality of these thoughts, which continued to plague Salomon throughout what remained of her life and failed to assimilate into her personal story, despite her attempts at creating context and narrative.

The relentless nature of the memories discussed in this section are evidence of Herman's concept of intrusion, one part of what she describes as the dialectic of trauma. Although reliving, or in Salomon's case continually representing, these traumatic experiences may indicate an attempt at healing, the anxiety she felt when recalling her father's incarceration, her inevitable inability to save her grandmother, and the feeling of extreme shock after hearing her grandfather's distressing news were all situations that Salomon was perhaps unable to completely assimilate into her personal narrative, regardless of the amount of times these memories invaded her psyche. I now briefly

\footnotetext{
${ }^{196}$ Salomon and Belinfante, Charlotte Salomon: Life? or Theatre?, 764; JHM: 4877. ${ }^{197}$ Ibid., 812; JHM: 4919v.
} 
examine structural characteristics and a sample of paintings from Life? or Theatre? that signify the opposite end of the dialectic of trauma: constriction.

\section{CONSTRICTION}

One of the primary symptoms of PTSD outlined by Herman is that of constriction, or an alteration of consciousness, perception, and sensations. ${ }^{198}$ Constriction may indicate a desire to avoid memories of the traumatic experience by creating a buffer between the individual and the event. Herman describes constriction as a reaction in which "the person may feel as though the event is not happening to her, as though she is observing from outside her body, or as though the whole experience is a bad dream from which she will shortly awaken." ${ }^{, 199}$ I contend that Salomon's use of third-person narrative in Life? or Theatre? indicates a method of dissociating from and circumventing the pain associated with the traumatic events that unfold in the series. In Life? or Theatre? Salomon observed and recorded her life from outside her self through her creation and manipulation of "Charlotte Kann," who relived and re-told the illustrated traumatic experiences on Salomon's behalf.

Her use of third person narrative also allowed her to embody each of the characters, which she did numerous times throughout the series. In one of the sheets discarded from the final version of Life? or Theatre?, she explained this feat by saying, "I was my mother, my grandmother, in fact I was all the characters who take part in my

${ }^{198}$ Herman, Trauma and Recovery, 42.

199 Ibid., 43. 
play. I learned to travel all paths and became all of them."200 Essentially, Salomon acts and speaks on behalf of each of her characters at some point in the series, which is consistent with Elaine Scarry's notion that "it is not surprising that the language for pain should sometimes be brought into being by those who are not themselves in pain but who speak on behalf of those who are."201 Thus, her embodiment of other characters is significant because it allowed her to represent and therefore assign context and narrative to the traumatic experiences of, for instance, her father, stepmother, and grandmother. Salomon presents herself with the predicament of integrating into her personal narrative the traumatic experiences of others, as well as her own.

Similarly, quoted above, Salomon elucidates to viewers how she worked on the project, saying, "He is painting. A tune suddenly enters his mind. As he starts to hum it, he notices that the tune exactly matches what he is trying to commit to paper," and signs these opening remarks as "Der Verfasser," or the Author. ${ }^{202}$ Pollock says of Salomon's use of the pronoun Der Mensch, that she refers to herself as "not a women and yet equally not a man, but a human creature." ${ }^{, 203}$ This ambiguity seems accurate, considering the pronoun alternates between "he" and "she" according to which contemporary text the passage is quoted in. For instance, many articles and essays that discuss Salomon's work

\footnotetext{
${ }^{200}$ Schultz and Timms, "Charlotte Salomon: Images, Dialogues, and Silences," 271, quoted from JHM: 4931-32.

${ }^{201}$ Elaine Scarry, The Body in Pain: The Making and Unmaking of the World (New York: Oxford University Press, 1985), 6.

${ }^{202}$ White, "Autobiography as Performative Identity Construction," 83.

${ }^{203}$ Pollock, "Theater of Memory," 62.
} 
replace "he" with "she" in this quote without any explanation. ${ }^{204}$ Regardless, this ambiguity is a useful technique in Salomon's quest to embody each of her characters.

By signing these opening remarks as "the Author," Salomon essentially denies or relinquishes personal responsibility for the actions that take place in Life? or Theatre? White supposes that using the first person would have "grounded Salomon in one location," and limited her ability to mold and adjust the experiences of the other characters in the series. ${ }^{205}$ This renouncement of authorship may be understood as a potential indication of constriction, or as Herman might argue, a sense of "subjective detachment. ${ }^{\not 206}$ Salomon substituted first-person narrative for omnipotence, which allowed her the freedom to embody and manipulate the characters in a way that might satisfy her own quest to assimilate traumatic experiences into her personal narrative.

Likewise, the overlays that cover the first two hundred sheets may be understood as yet another degree of separation from the traumatic events portrayed in Life? or Theatre? Herman describes further how this element of constriction incites "indifference," and "emotional detachment. ${ }^{, 207}$ Given this, perhaps these overlays functioned as another way of formulating her emotional distance from the horrors that Salomon depicts. Instead of engaging her narration directly in the action, the sheets provided Salomon with a vehicle that allowed her to hover above the fray.

I would now like to briefly examine two specific series of paintings in Life? or Theatre? that signify constrictive symptoms. To begin, I discuss three paintings that

\footnotetext{
${ }^{204}$ This is the case in Timms and Schultz, "A Multimedia Response to the Crisis of German Culture," 255, and in Salomon and Belinfante, Charlotte Salomon: Life? or Theatre?, 45; JHM: 4155-5.

${ }^{205}$ White, "Autobiography as Performative Identity Construction," 83.

${ }^{206}$ Herman, Trauma and Recovery, 43.

207 Ibid., 43.
} 
denote Salomon's despair at being sent into exile, which have no accompanying text yet resonate deeply with viewers. JHM: 4808 and 4824 (Figures 37 and 38) convey the heartbreaking inevitability of leaving Berlin. In them, Salomon shows herself in her room, contemplating what to take with her to France. ${ }^{208}$ Both images portray a forlorn Salomon opposite an open suitcase. In the first image, she sits on her bed, facing the suitcase. In Figure 37, Salomon depicts a pile of books and a tennis racket sitting outside her suitcase, making it clear that these non-essential items will not make the journey to France. Figure 38 shows Salomon sitting on a closed suitcase, reflecting on what should go in the open case sitting on her bed. In both images, Salomon paints an obviously distraught version of herself, words having escaped both of them.

The final silent scene of the Main Section shows Salomon in profile on the train headed to France (Figure 39) ${ }^{209}$ She has said her final good-byes to Dr. Salomon, Lindberg, and Wolfsohn, not knowing at the time that this farewell was to be forever. Salomon sits in her seat, her hands on the windowsill, watching Berlin fade into the background. This and the two previous scenes rely solely on visual aspects to depict Salomon's memory. White asserts that instead of employing words to explain how she felt and why, Salomon's use of the visual "does more to preserve the intensity of the experience, and it thus explains to the audience the serious effect that exile from Germany had on Salomon's identity."210

Why was Salomon unable to assign text to these poignant moments? Many scholars argue that leaving Berlin was such an overwhelming experience for Salomon

${ }^{208}$ Salomon and Belinfante, Charlotte Salomon: Life? or Theatre?, 694, 710; JHM: 4808 $\& 4824$, respectively.

${ }^{209}$ Ibid., 719; JHM: 4833.

${ }^{210}$ White, "Autobiography, Visual Representations, and the Preservation of Self." 
that words simply could not describe her despair. For example, Schultz and Timms suggest that in these silent images, "sounds are suppressed at the moment when feelings are at their most intense, as if they are too powerful to be uttered, or comprehended."211 Leaving Berlin was a turning point in Salomon's life; leaving her parents and her home behind was probably a memory she would rather forget.

However, this lack of text could be considered an example of constriction. In response to traumatic memories, Herman says that victims feel a sense of "profound passivity," and in turn, renounce any kind of initiative or struggle. ${ }^{212}$ These images that depict the events leading up to Salomon's flight from Berlin are indicative of such profound passivity. It is unsurprising that she would not, or could not, narrate these pages, as they illustrate a fundamental moment in her predicament. Perhaps Salomon was not ready to attach any text or emotion to these memories, which again indicates the notion that her healing process was incomplete.

Conversely, the last painting discussed here consists of only text (Figure 40). It is from the Epilogue, and illustrates the Nice announcement stating that she and her grandfather, as German nationals, should "leave without delay.",213 This page contains the only allusion in Life? or Theatre? to Salomon and Mr. Grunwald's imprisonment at Gurs. That the page consists of text without an image, and is devoid of any emotional commentary provides evidence of how little Salomon's attempt at self-guided therapy was progressing. Herman says that "a narrative that does not include the traumatic imagery and bodily sensations is barren and incomplete," and that "the recitation of facts

${ }^{211}$ Schultz and Timms, "Charlotte Salomon: Images, Dialogues, and Silences," 275. ${ }^{212}$ Herman, Trauma and Recovery, 43.

${ }^{213}$ Salomon and Belinfante, Charlotte Salomon: Life? or Theatre?, 802; JHM: 4914. 
without the accompanying emotions is a sterile exercise. ${ }^{, 214}$ With this in mind, it seems likely that Salomon was not ready to externalize these memories visually, or "feel" them in any way, other than the portrayal of a detached narration of facts. While she was able to reconstruct her father's internment in Sachsenhausen using her imagination, she was unable to record, or attach any emotion to, her own experience at Gurs.

Pollock assumes that Salomon's experience at Gurs, although brief, was shocking beyond any comprehension and was in fact "the precipitating horror out of which Life? or Theatre? was conceived." 215 Pollock follows Felstiner in this line of thinking in regard to the possible notion that Gurs was the impetus for Life? or Theatre? Felstiner asserts that "her time in the camp formed a parenthesis. But it was also a genesis. Imprisonment gave her a premonition, release a reprieve, that spurred her to paint her life."216

In over one year's time and in more than 1,300 paintings, Salomon never reflected on her time in the concentration camp, which perhaps indicates the idea that these memories remained in their dissociated state; she would not, as Herman might contend, "allow" herself to think about Gurs. These traumatic memories were, following Janet, "preserved in an abnormal state, set apart from ordinary consciousness." 217 Salomon was conceivably not able or ready to confront these traumatic memories and therefore chose to keep them walled off from ordinary consciousness. In this vein, Felstiner asserts that the memories of Gurs violated "the deepest part of herself," and that "their exclusion

\footnotetext{
${ }^{214}$ Herman, Trauma and Recovery, 177.

215 Pollock, "Theater of Memory," 44.

${ }^{216}$ Felstiner, To Paint Her Life, 124.

${ }^{217}$ Ibid., 34.
} 
from Life? or Theatre? was a necessary defense mechanism." ${ }^{218}$ This omission is significant because it indicates that Salomon's integration process was not completed with the conclusion of Life? or Theatre? The series is evidence of a work in progress instead of a comprehensive example of healing.

${ }^{218}$ Ibid., 125. See also Schultz and Timms, "Charlotte Salomon: Images, Dialogues, and Silences," 277. 


\section{CONCLUSION}

Creating Life? or Theatre? was, in part, an attempt for Salomon to reconstruct, contextualize, and narrate traumatic memories and allow them to become part of her personal narrative. Like White, van Alphen, and Pollock suggest, this comprehensive work served as a way for Salomon to prescribe meaning to traumatic memories, and allow them to assimilate into existing, or newly created, mental frameworks. The paintings are the filmic still-like images that Herman discusses; in many cases the written narrative coupled with the accompanying musical score are literally the music and the words necessary to facilitate the integration of traumatic memories into Salomon's personal story.

However, Salomon's incessant representation of specific memories, coupled with various structural characteristics and the silence or evasion of particularly traumatic experiences, also indicate that Salomon's self-guided therapy was flawed; it was incomplete. While Salomon tried to come to terms with her traumatic past, as evidenced in the examples discussed above, there were some events that either continuously assailed her thought process, or that she simply could not record, and therefore integrate into her personal narrative. After examining specific examples of the oscillation between intrusion and constriction, it is clear that Life? or Theatre? is a visual manifestation of Salomon's personal dialectic of trauma. 
In the last painting in the series, "Charlotte Kann" sits on a beach, canvas in hand, looking out at the Mediterranean Sea (Figure 41). The words "Life or Theatre" are inscribed on her back. ${ }^{219}$ This painting is intended to denote the beginning of the arduous, yet therapeutic, task of coming to grips with her past by creating something "wildly eccentric." We therefore end at the beginning of what becomes a monumental, though imperfect, documentation of therapy and acceptance. Although she was eventually murdered by the Nazis, Salomon chose to live what remained of her life on her own terms, and left behind a record of her path toward a fully engaged existence.

${ }^{219}$ Salomon and Belinfante, Charlotte Salomon: Life? or Theatre?, 824; JHM: 4925. 
FIGURES

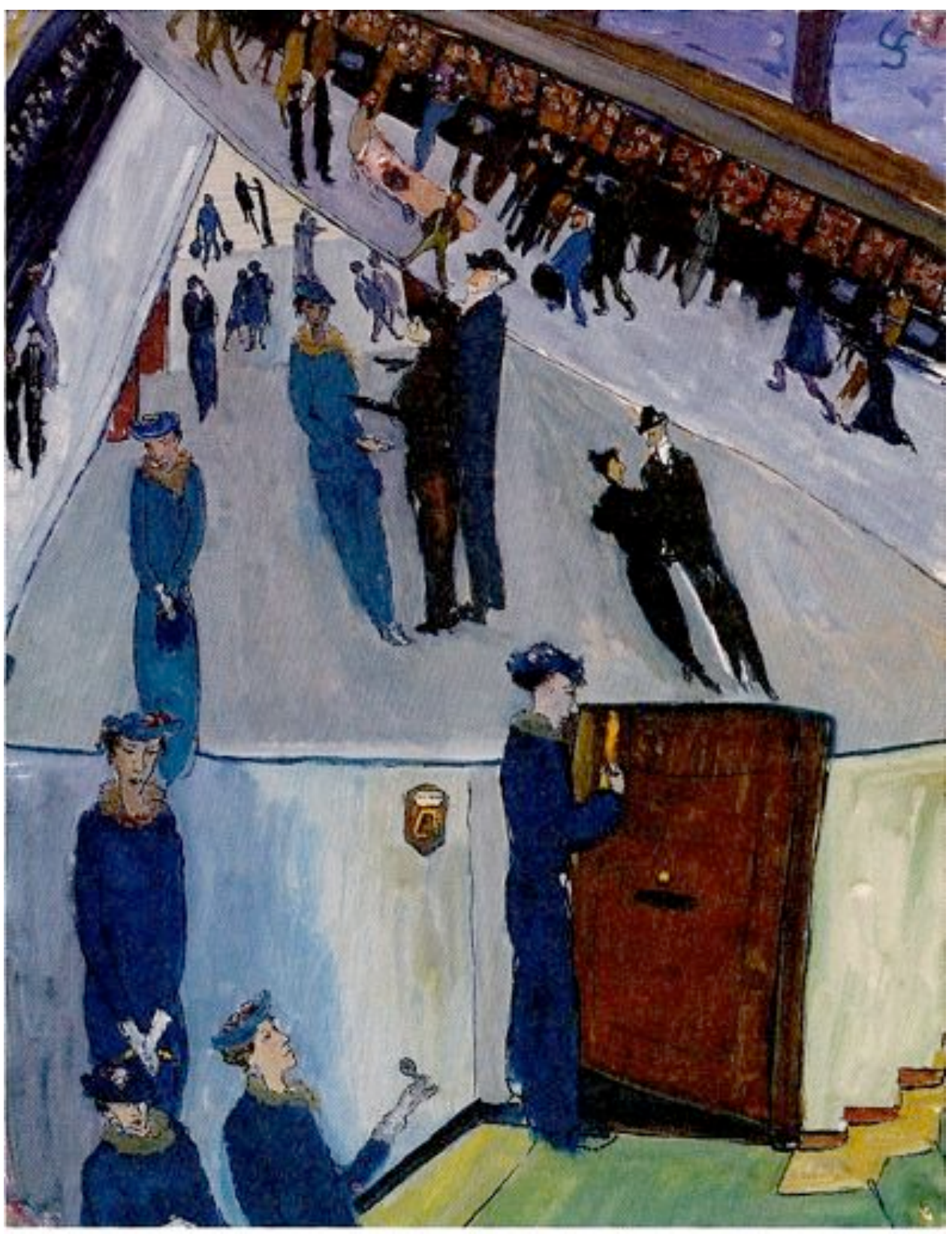

Figure 1

JHM: 4167 


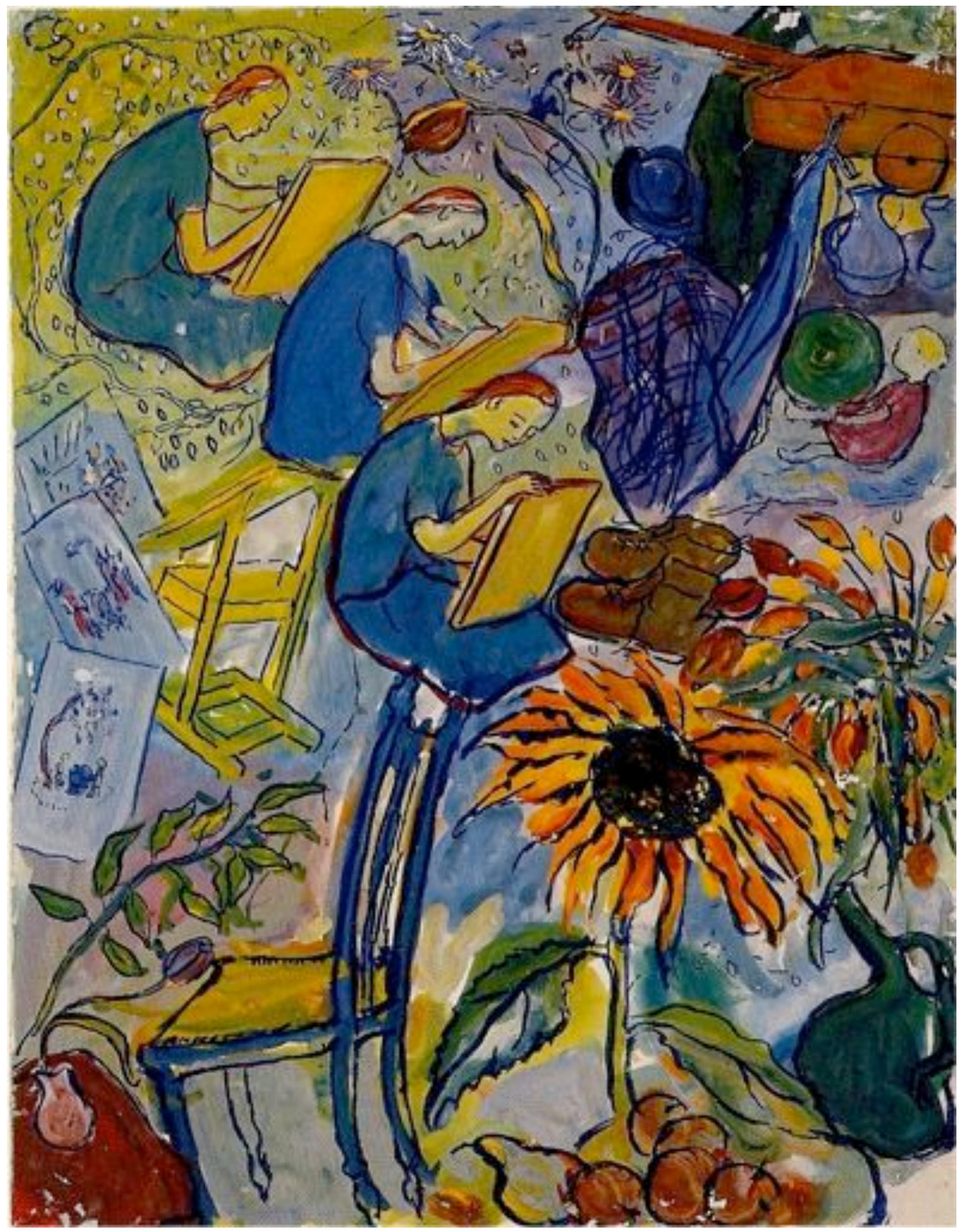

Figure 2

JHM: 4351 


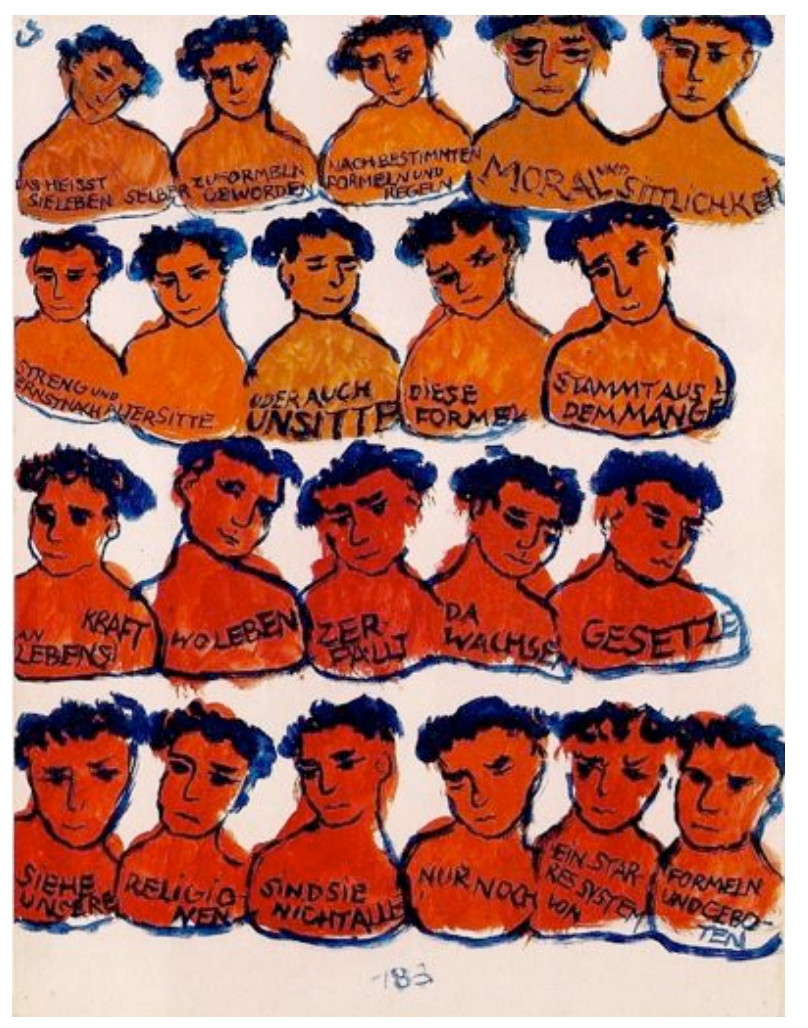

Figure 3

JHM: 4562

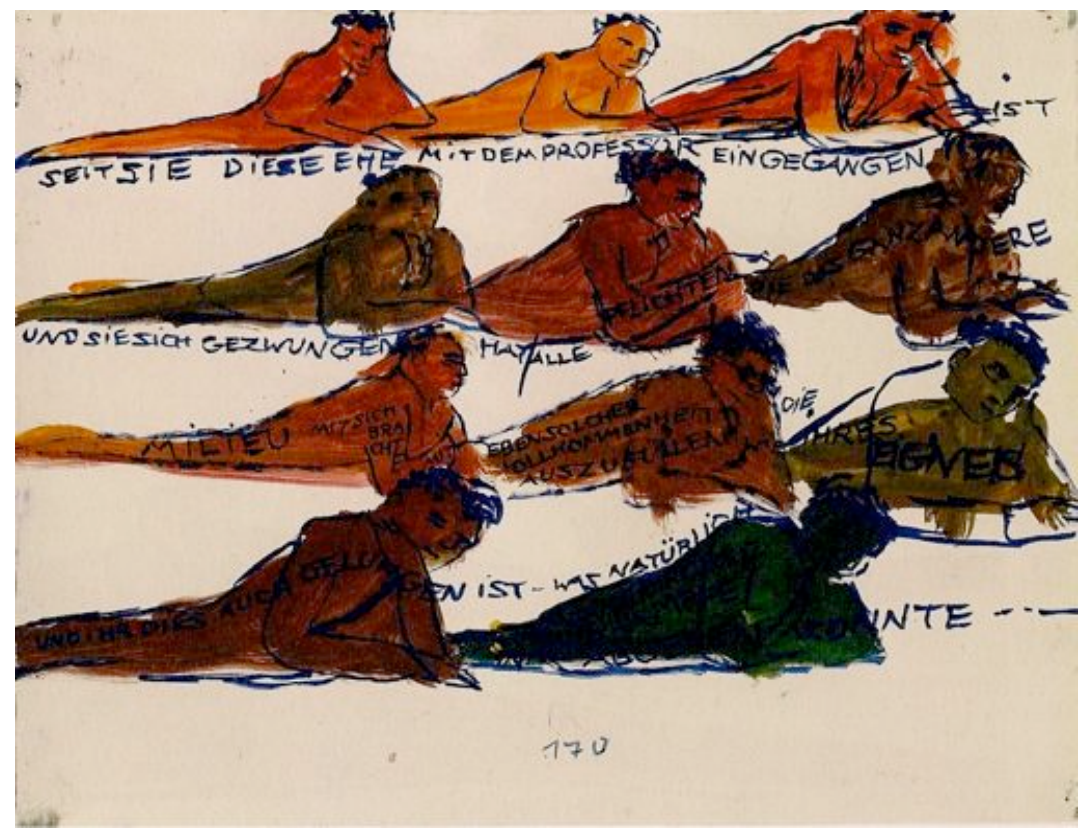

JHM: 4540

Figure 4 


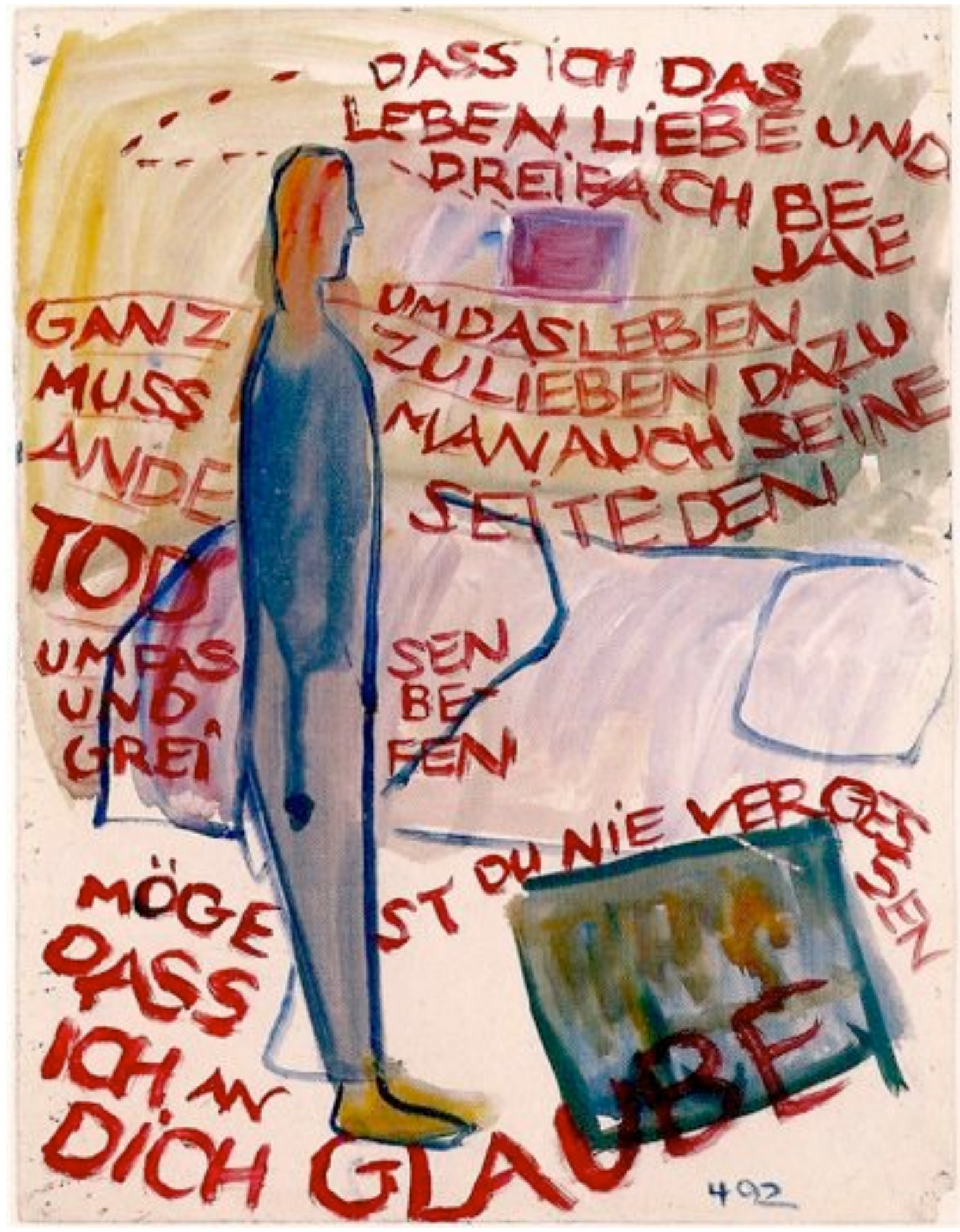

Figure 5

JHM: 4870 


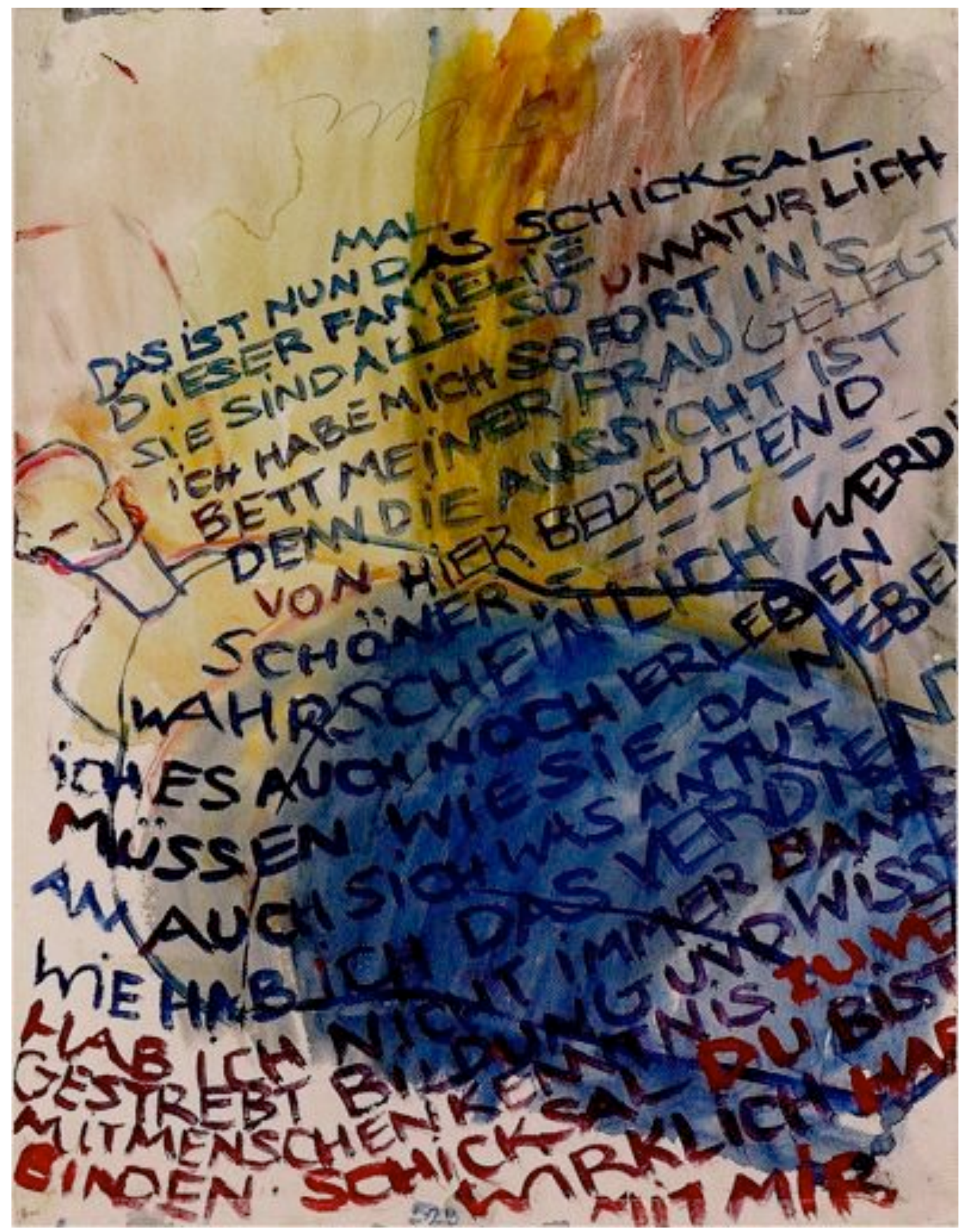

Figure 6

JHM: 4905 


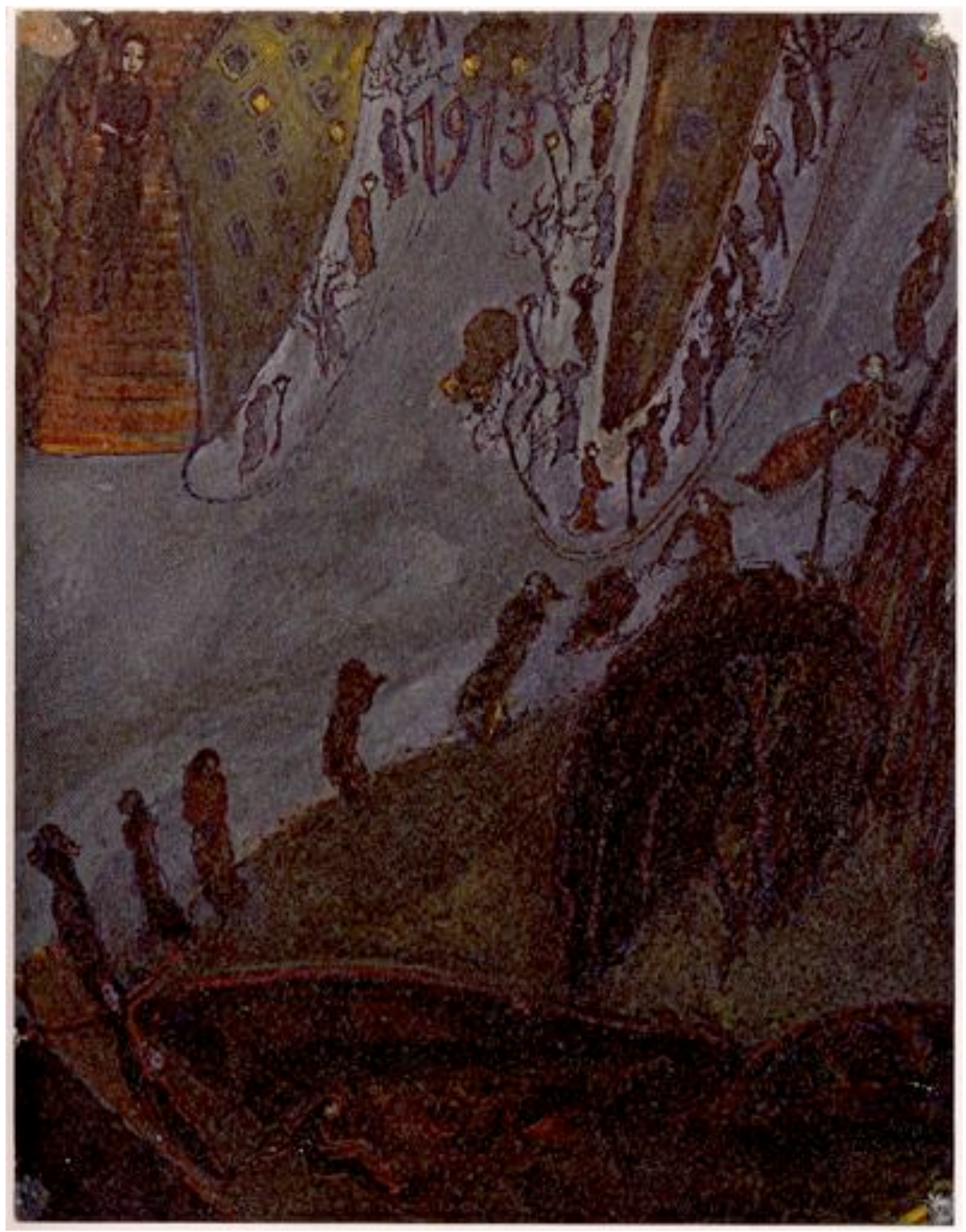

Figure 7

JHM: 4156 


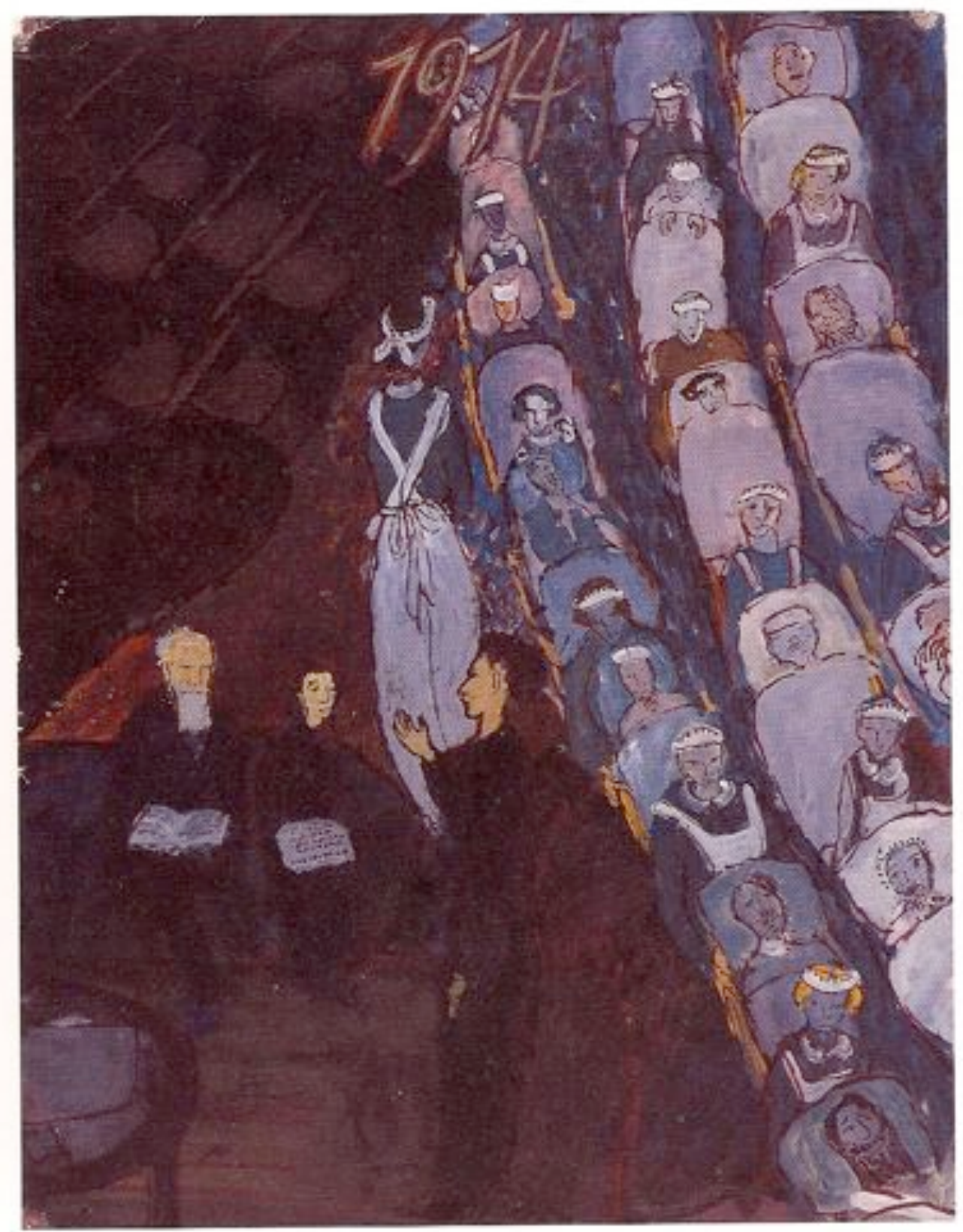

Figure 8

JHM: 4158 


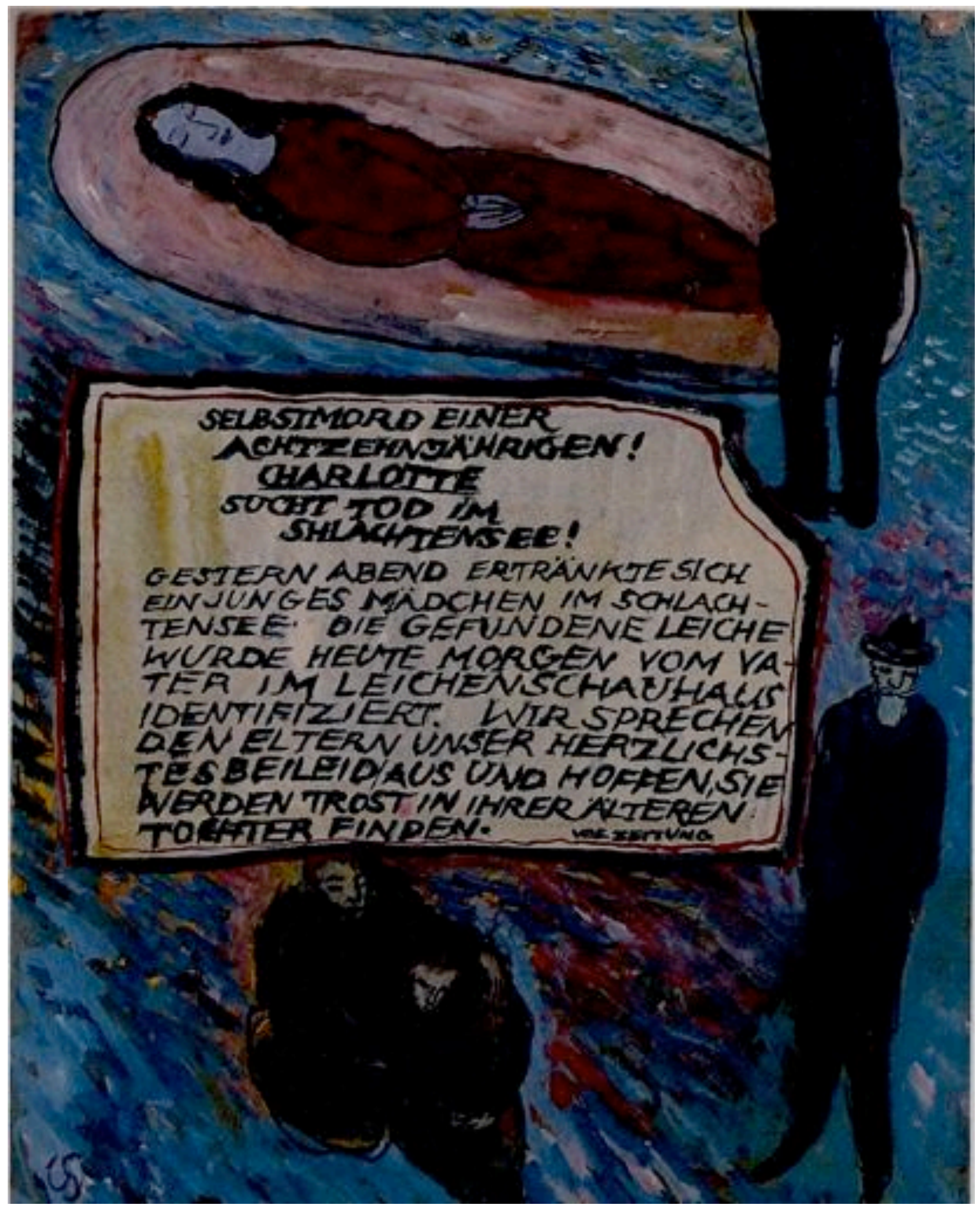

Figure 9

JHM: 4157 


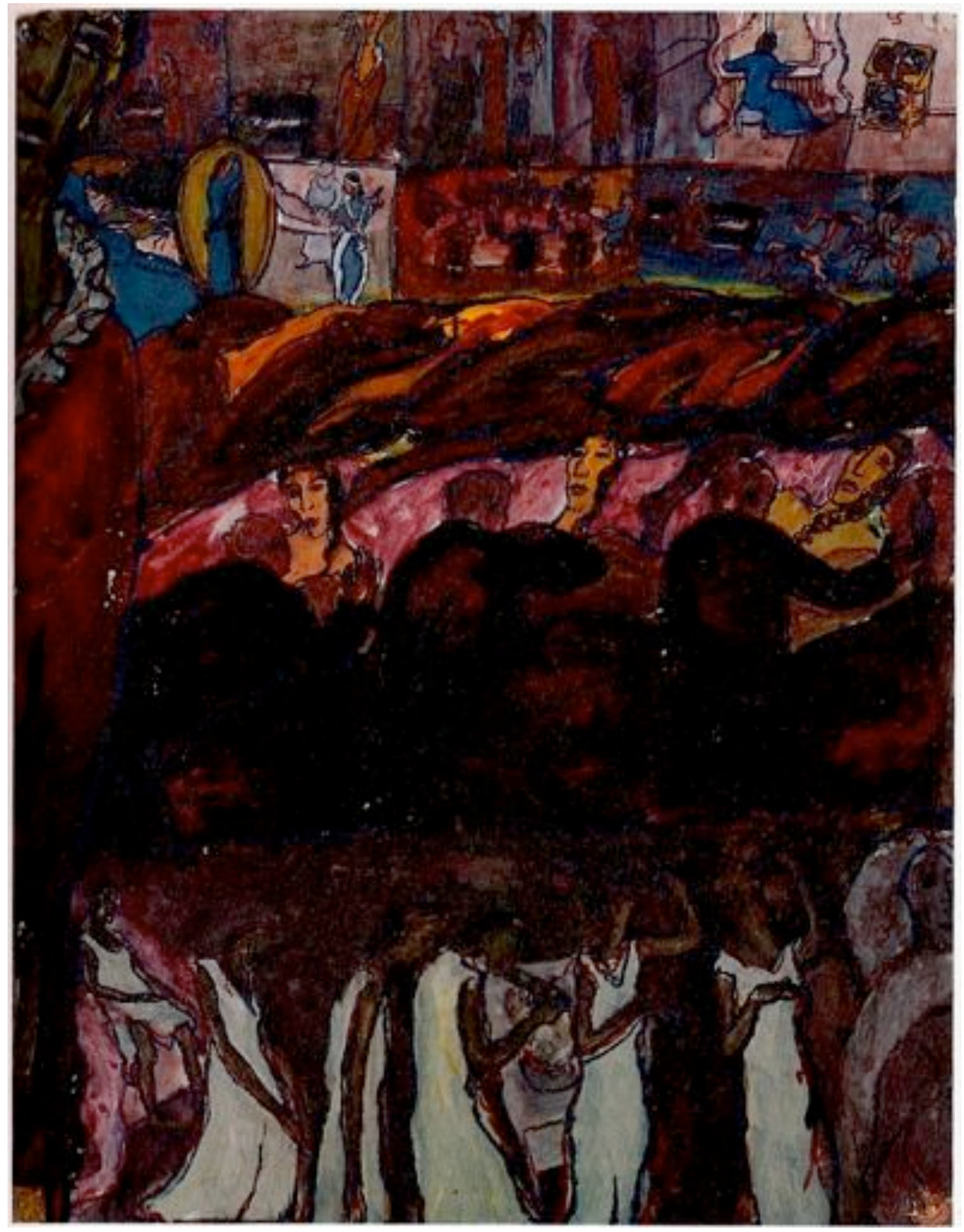

Figure 10

JHM: 4176 


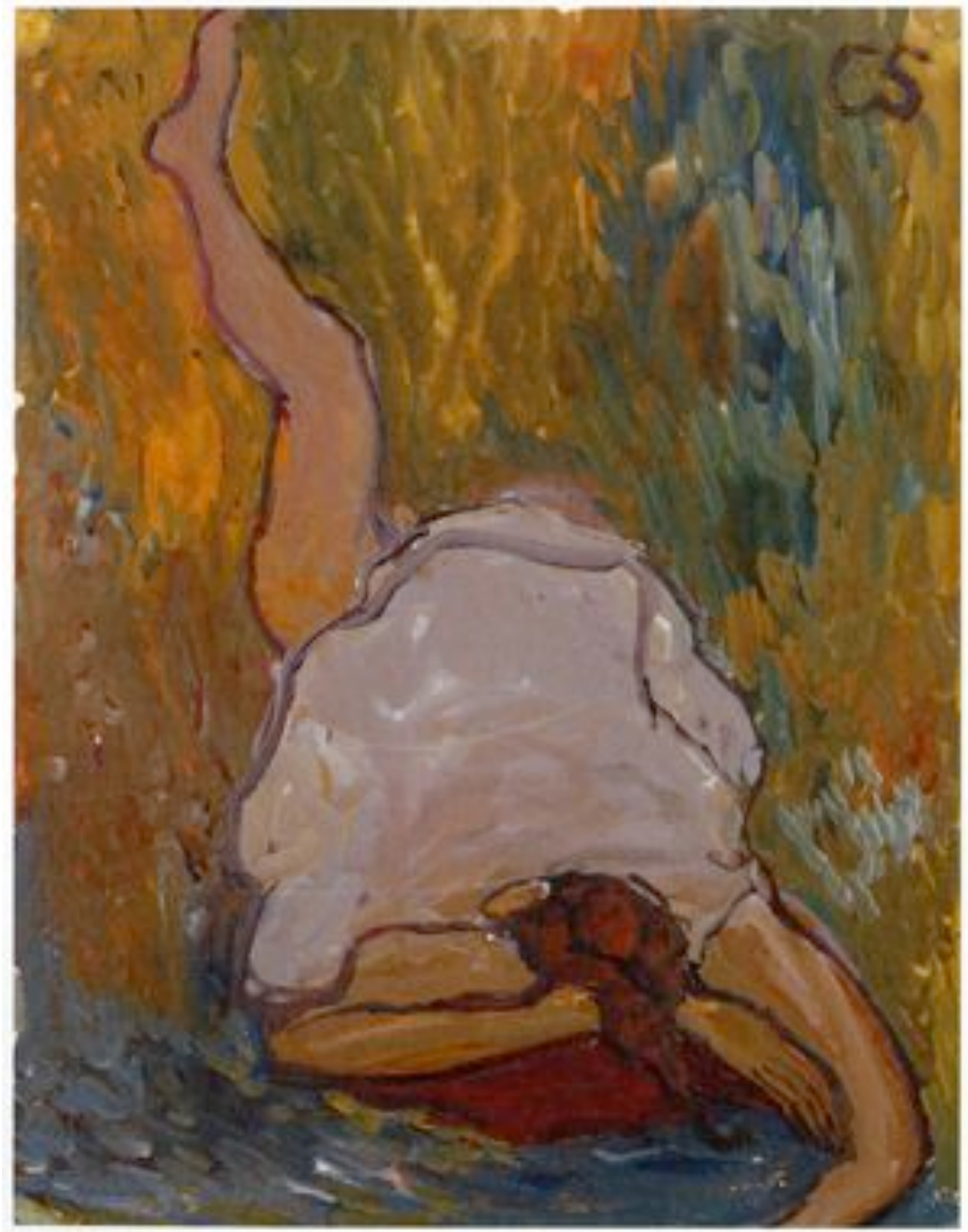

Figure 11

JHM: 4181 


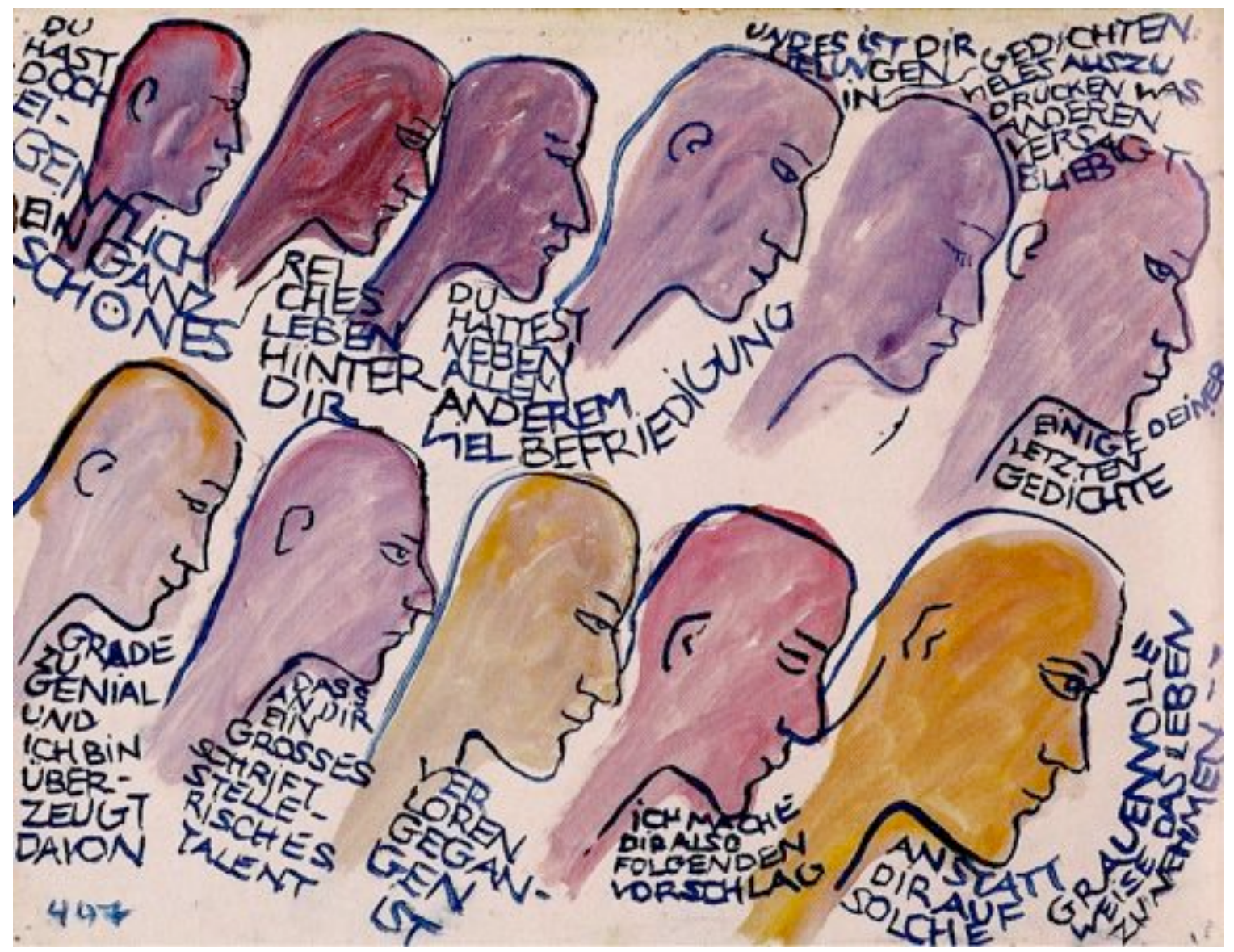

Figure 12

JHM: 4875 


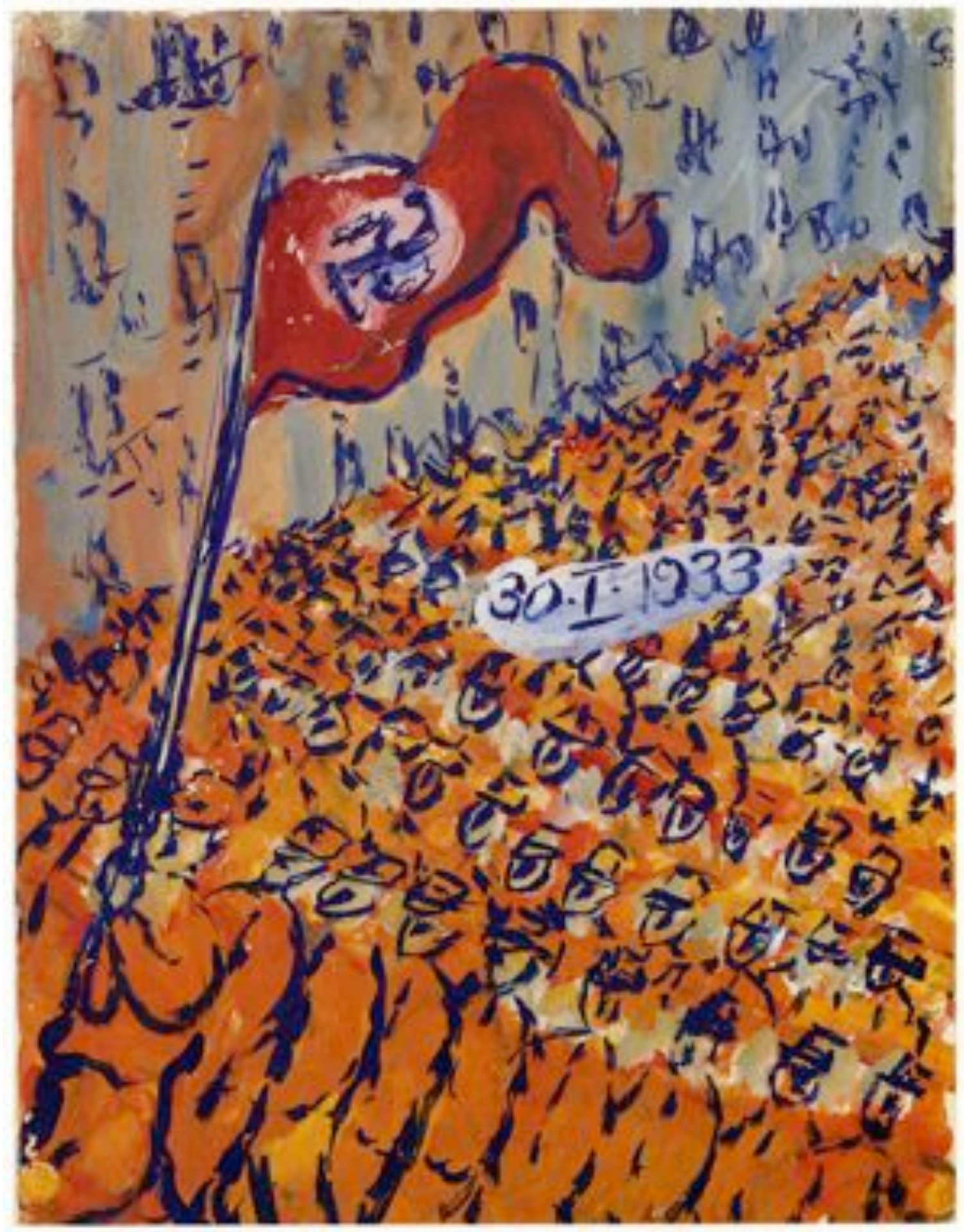

Figure 13

JHM: 4304 


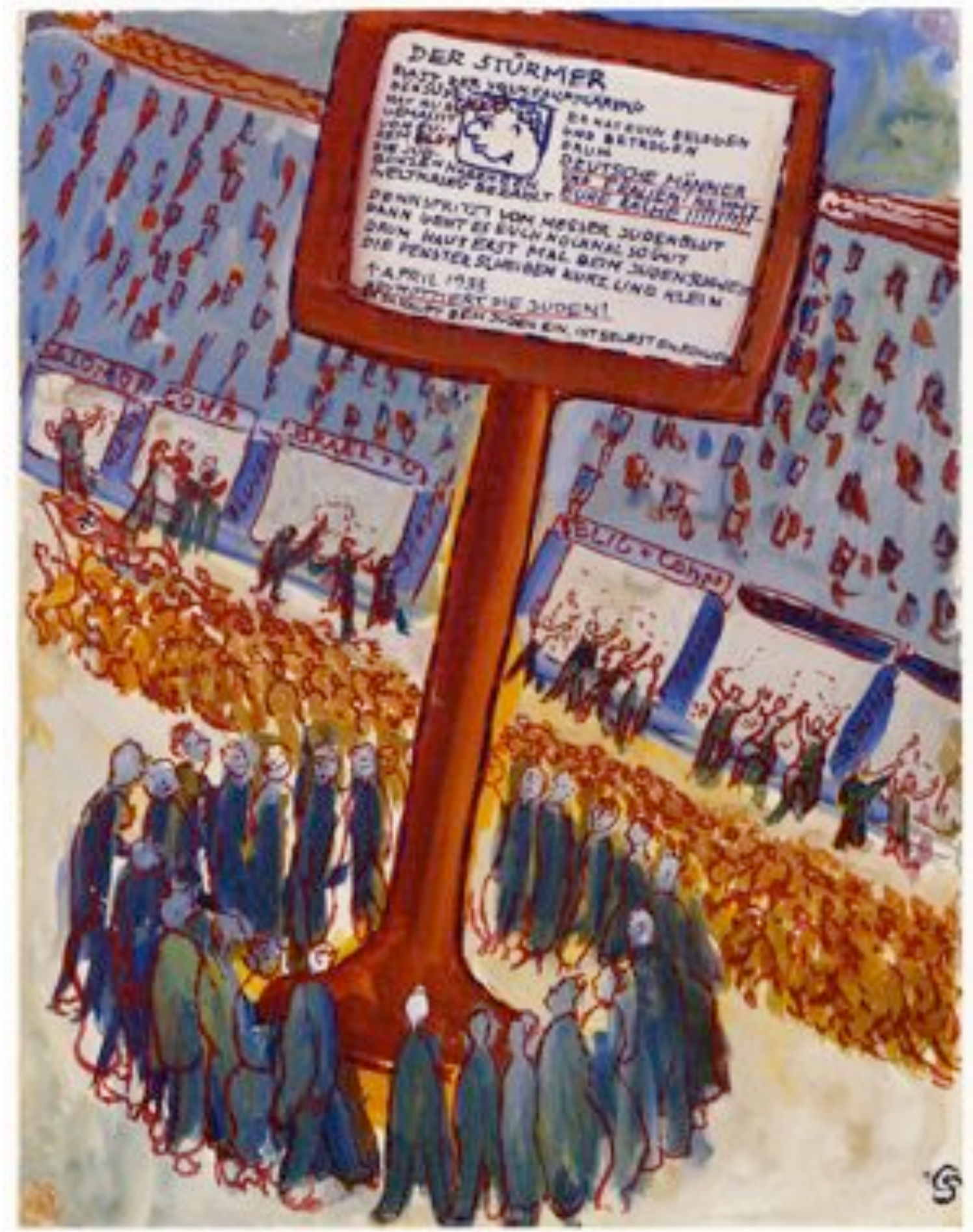

Figure 14

JHM: 4305 


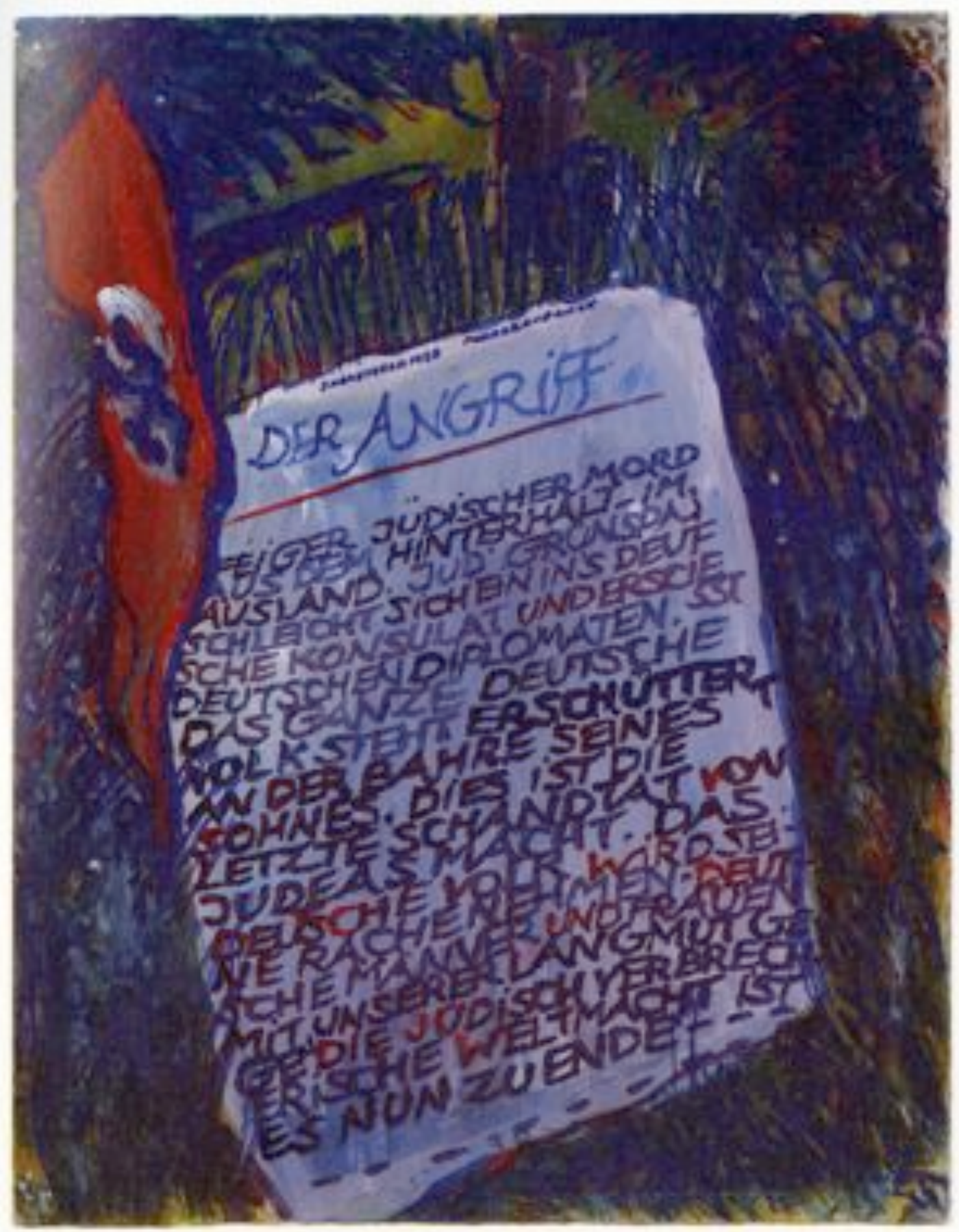

Figure 15

JHM: 4761 


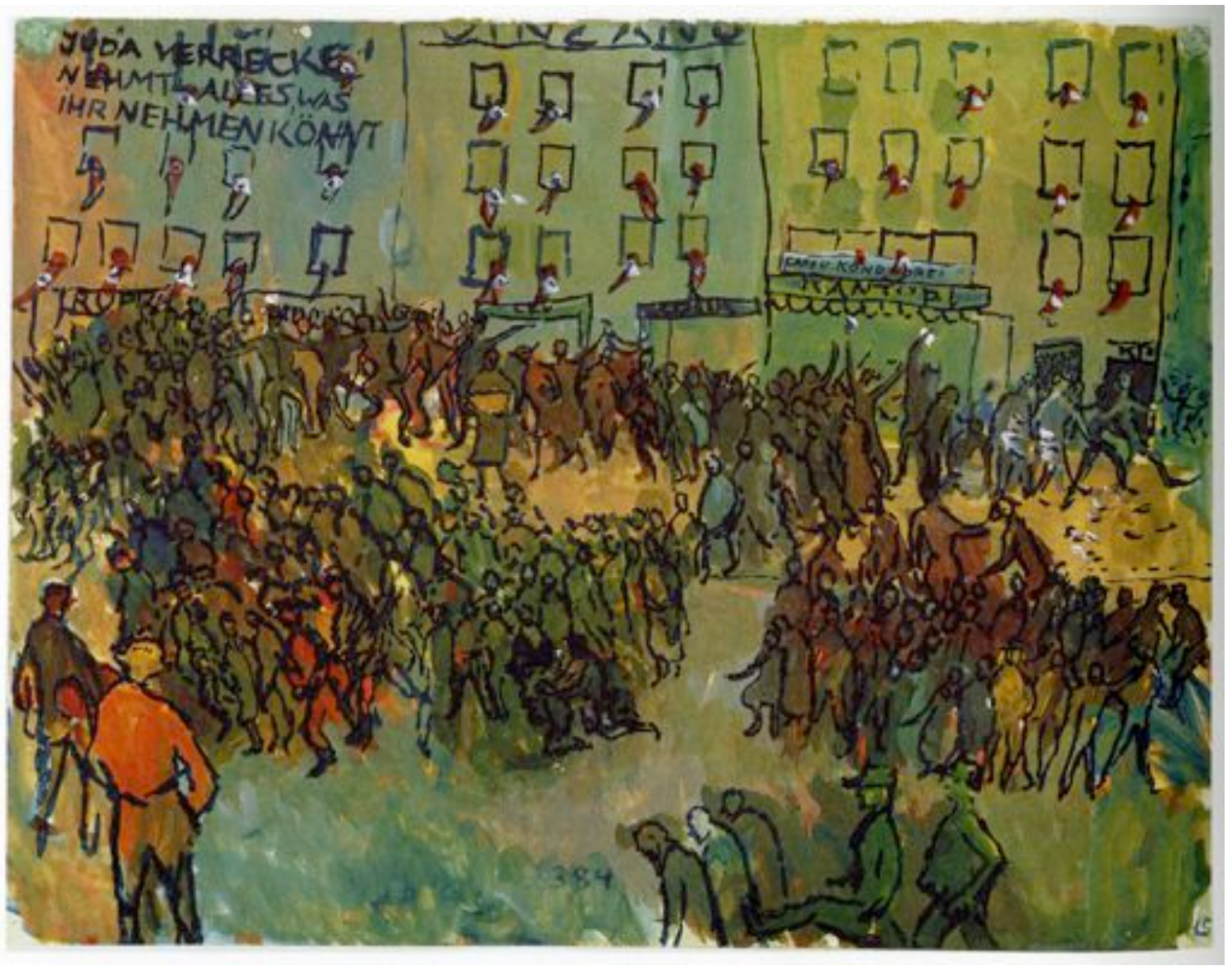

Figure 16

JHM: 4762 


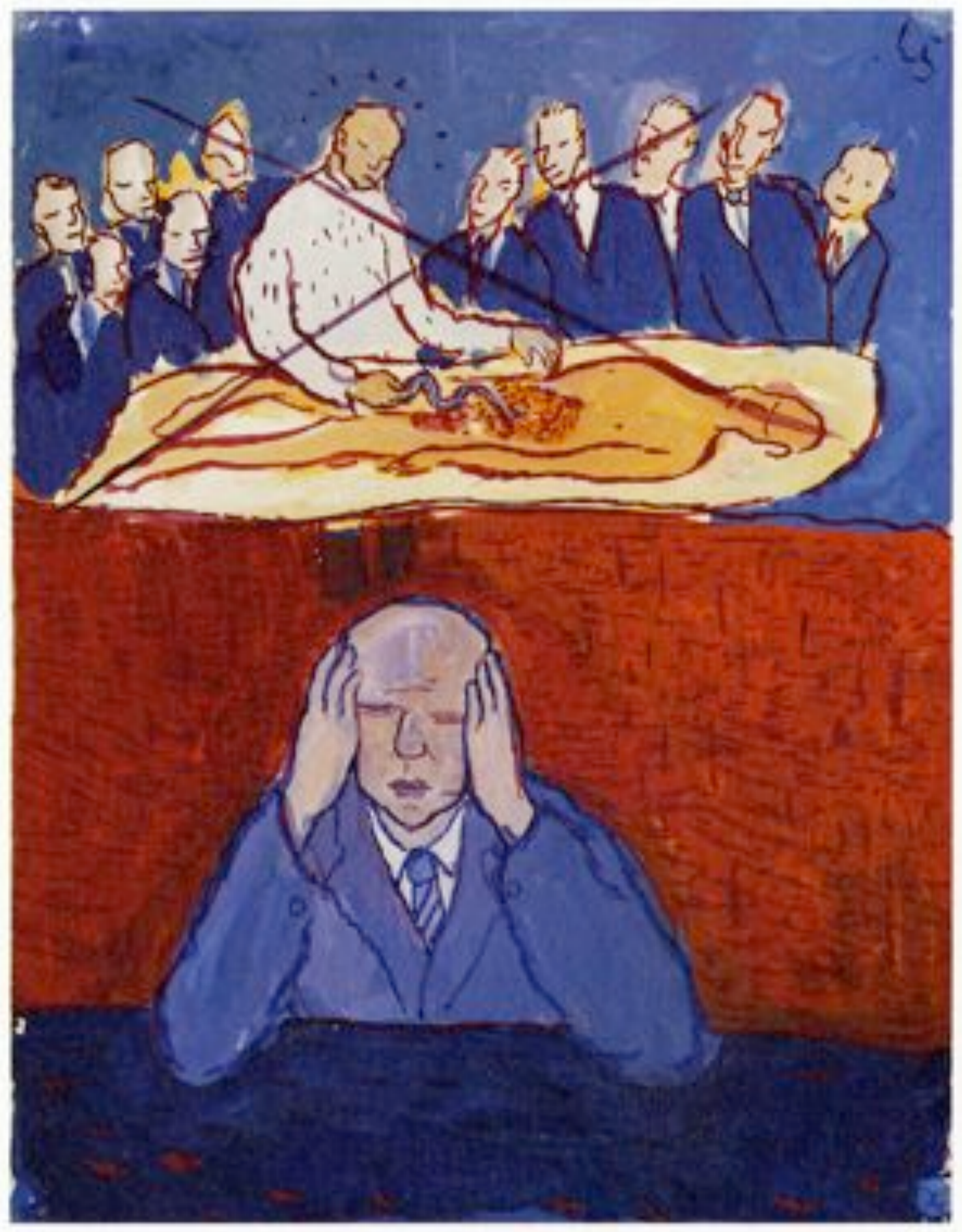

Figure 17

JHM: 4306 


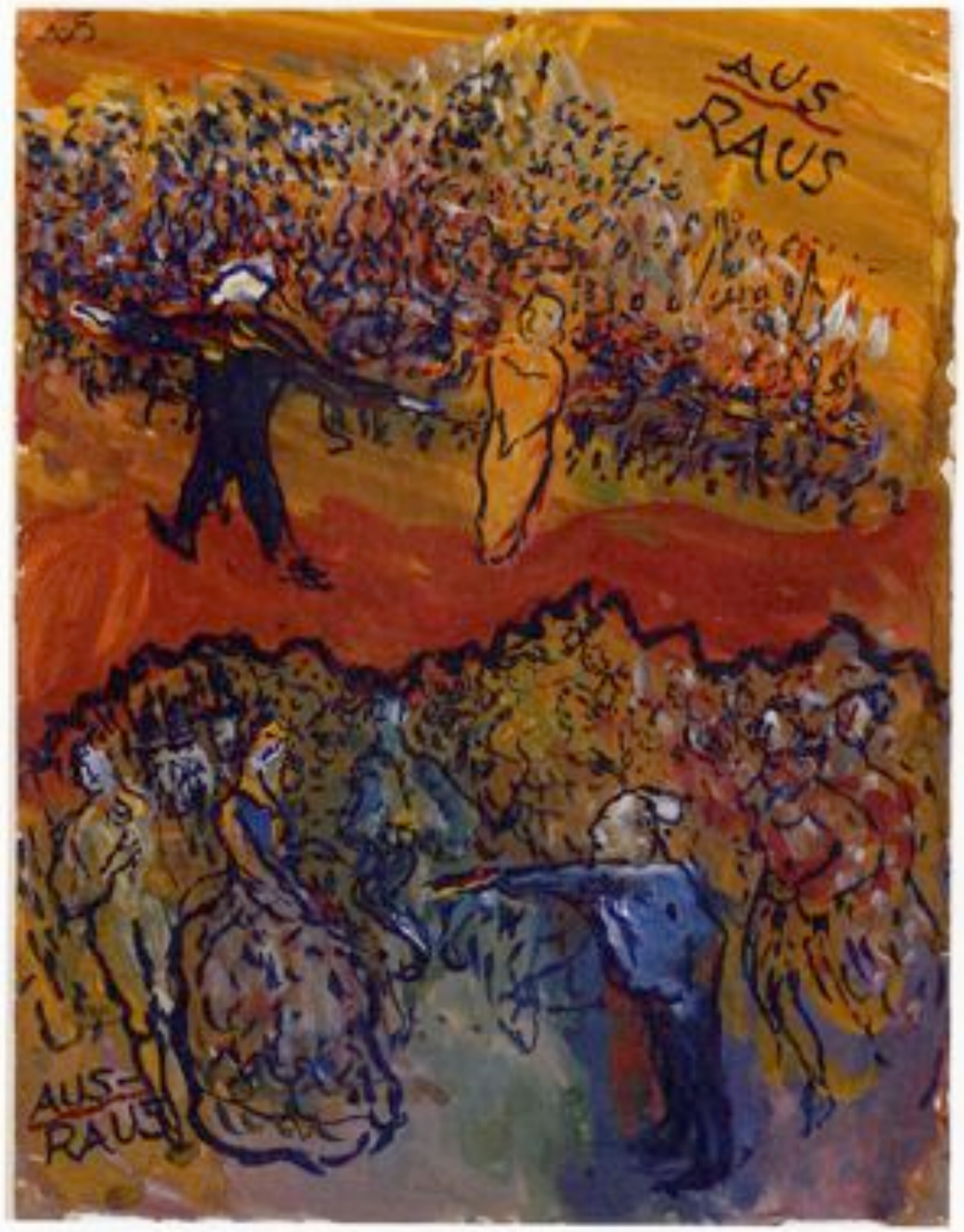

Figure 18

JHM: 4308 


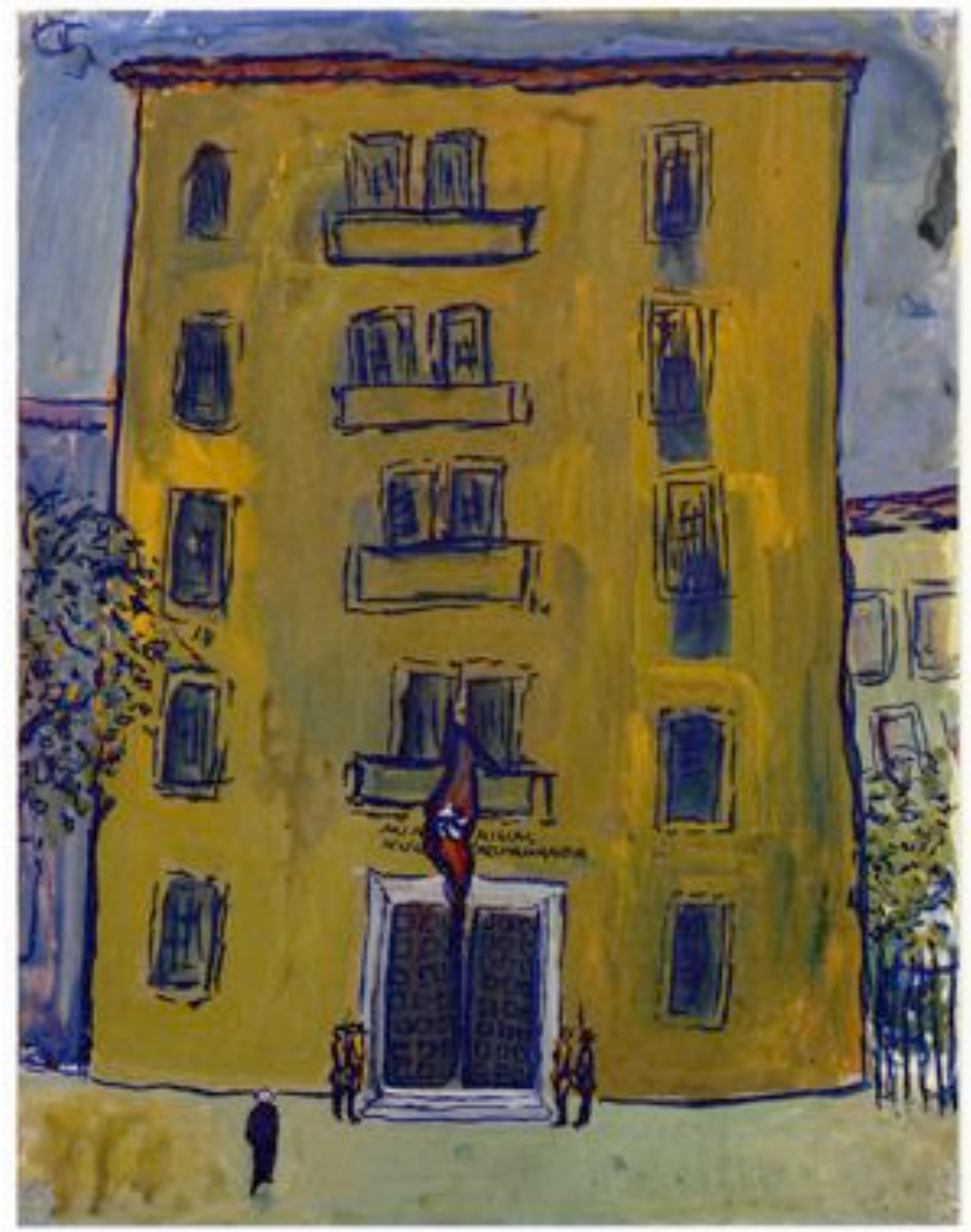

Figure 19

JHM: 4312 


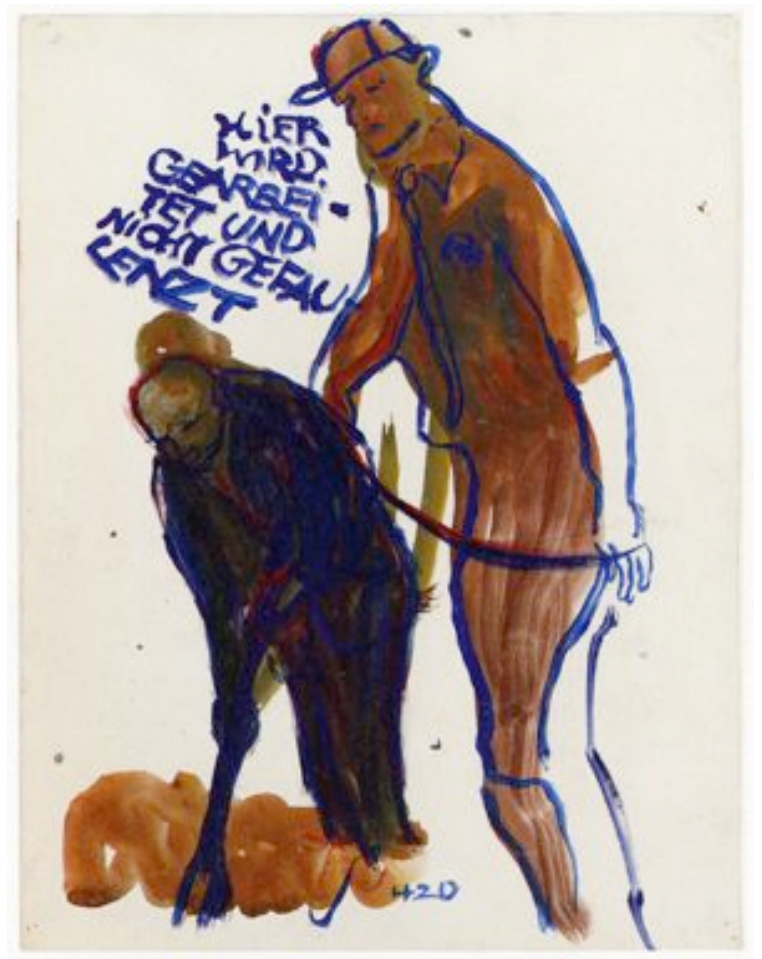

Figure 20

JHM: 4798

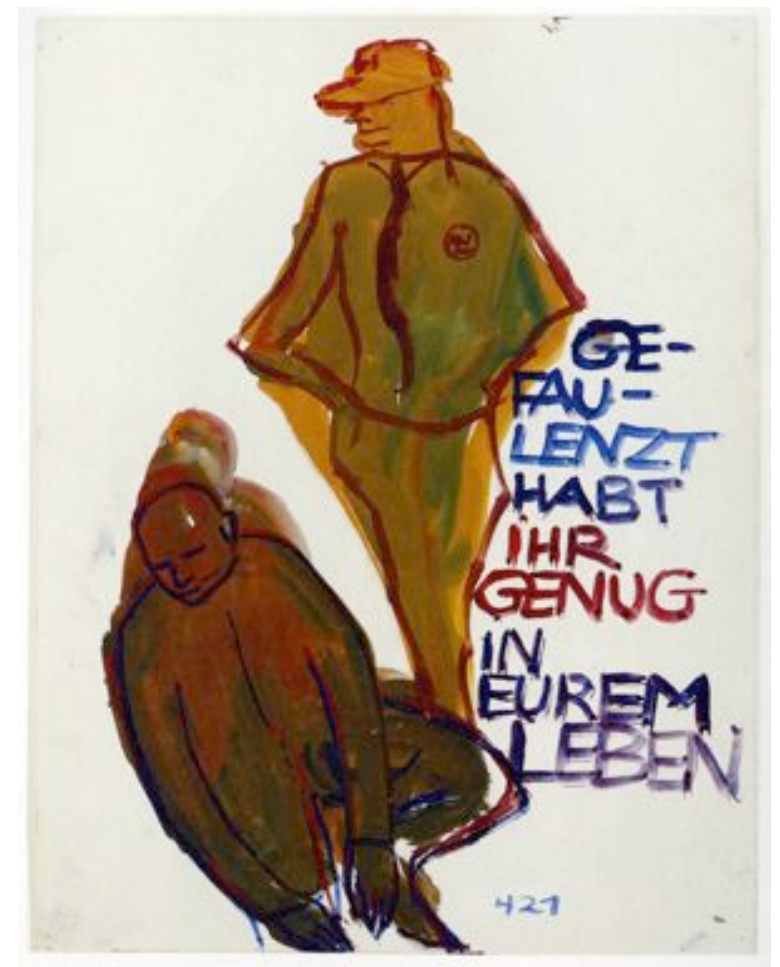

Figure 21

JHM: 4799 


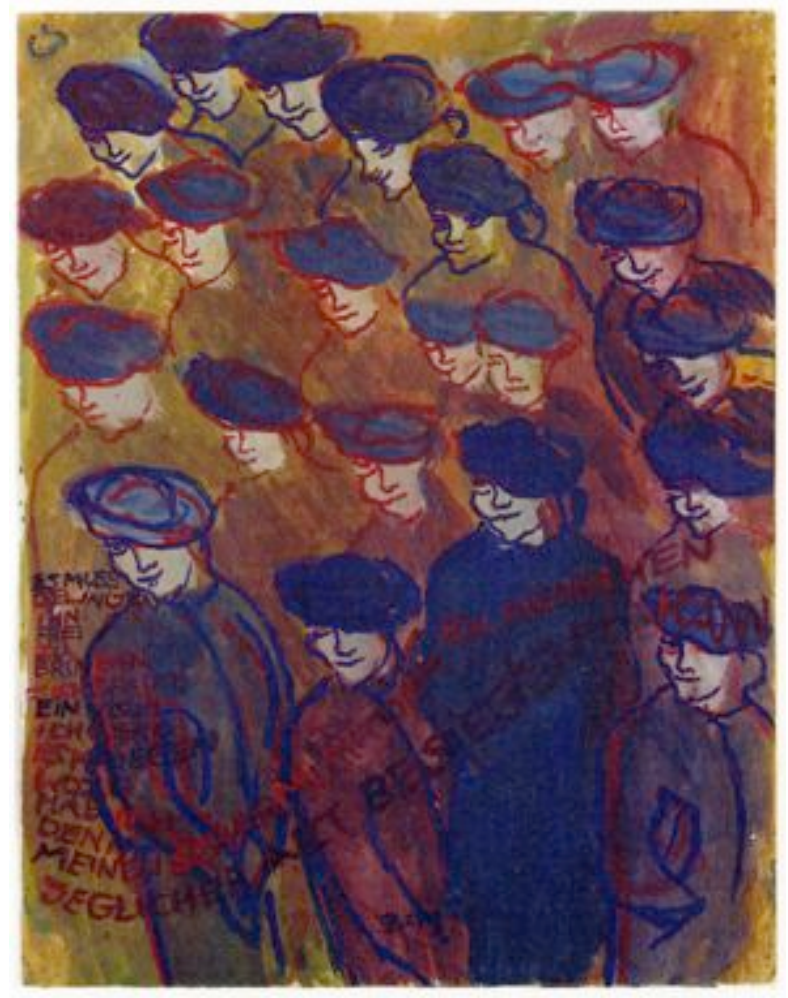

Figure 22

JHM: 4769

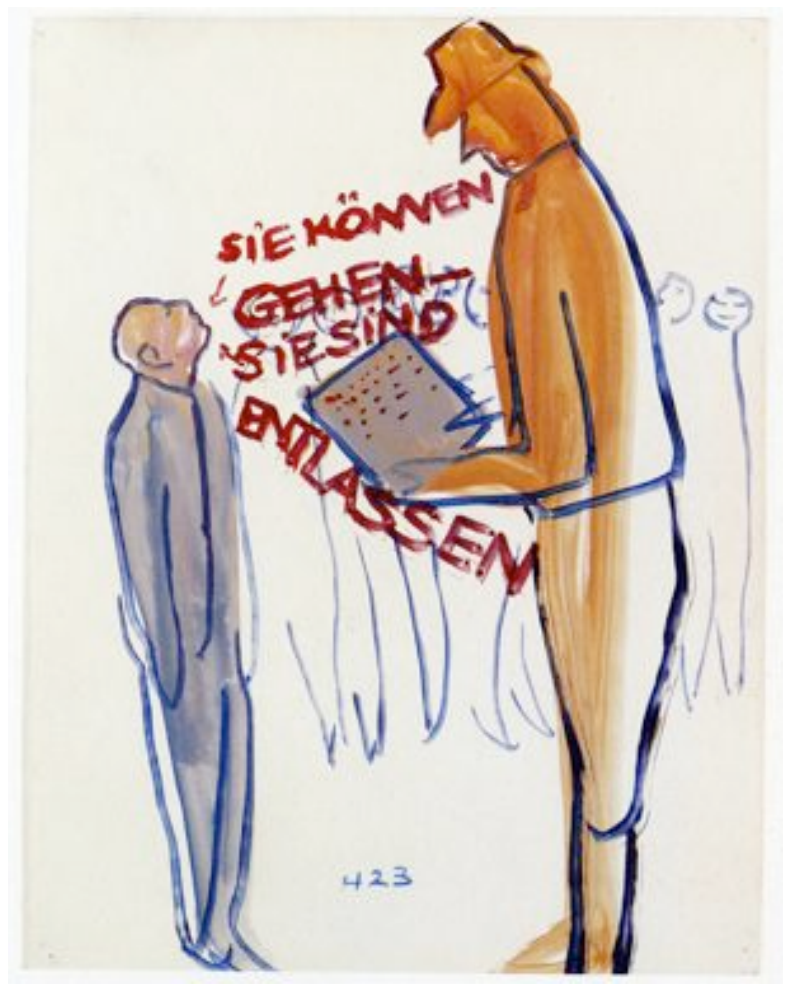

Figure 23

JHM: 4801 


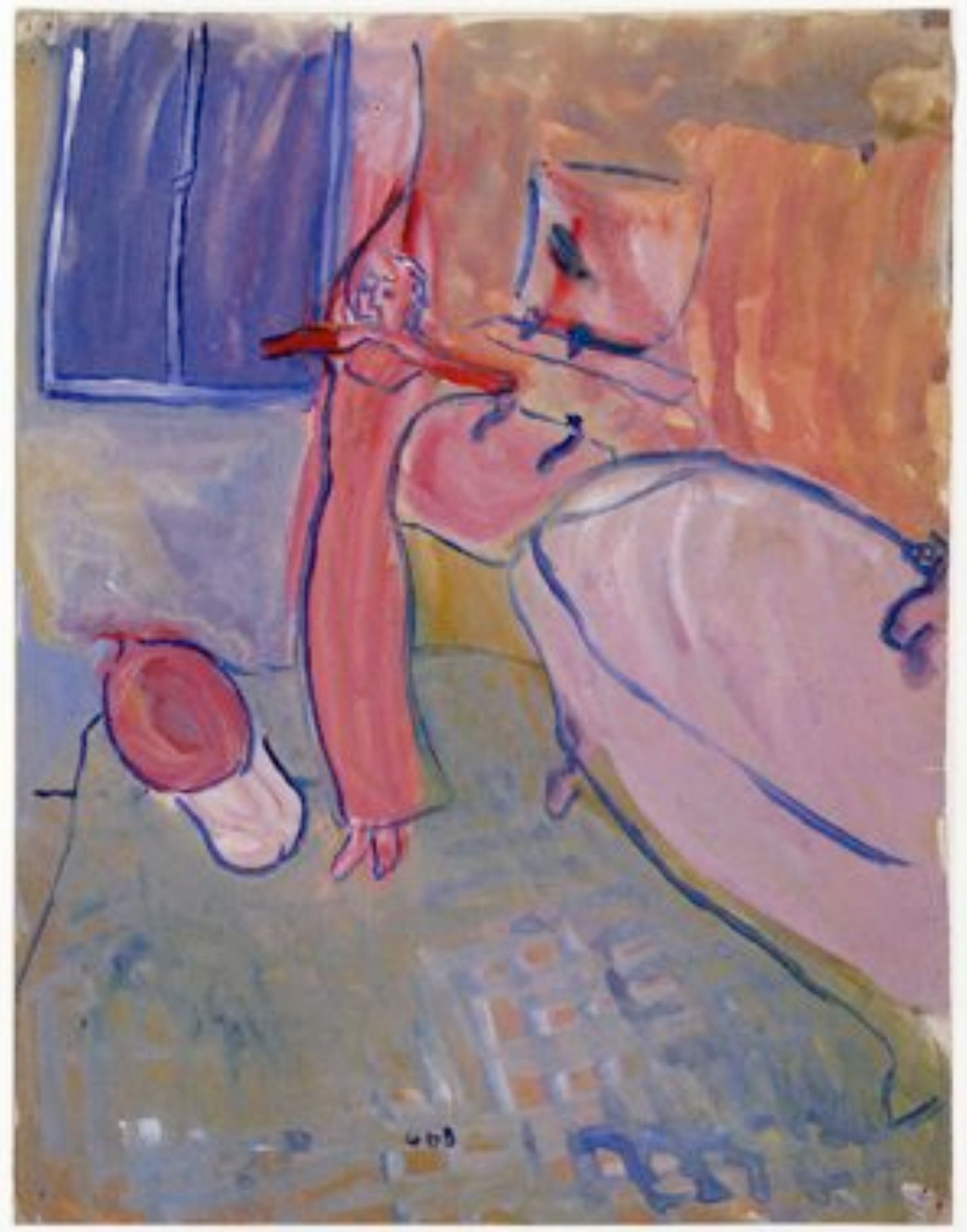

Figure 24

JHM: 4846 


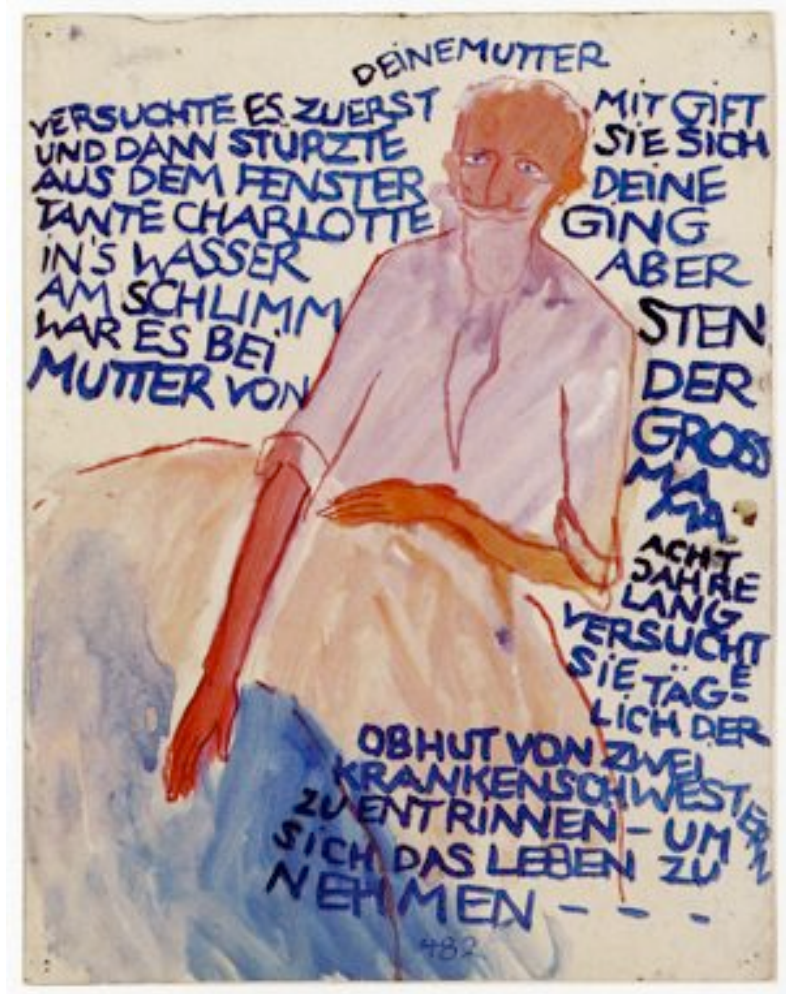

Figure 25

JHM: 4860

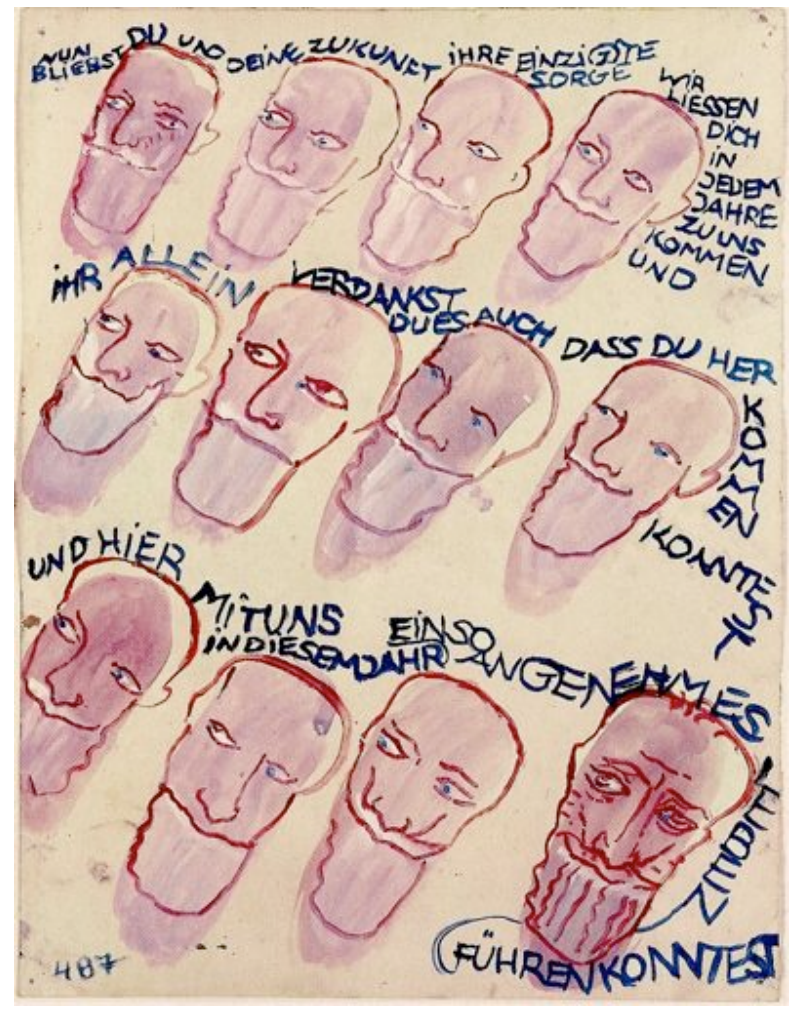

Figure 26

JHM: 4865 


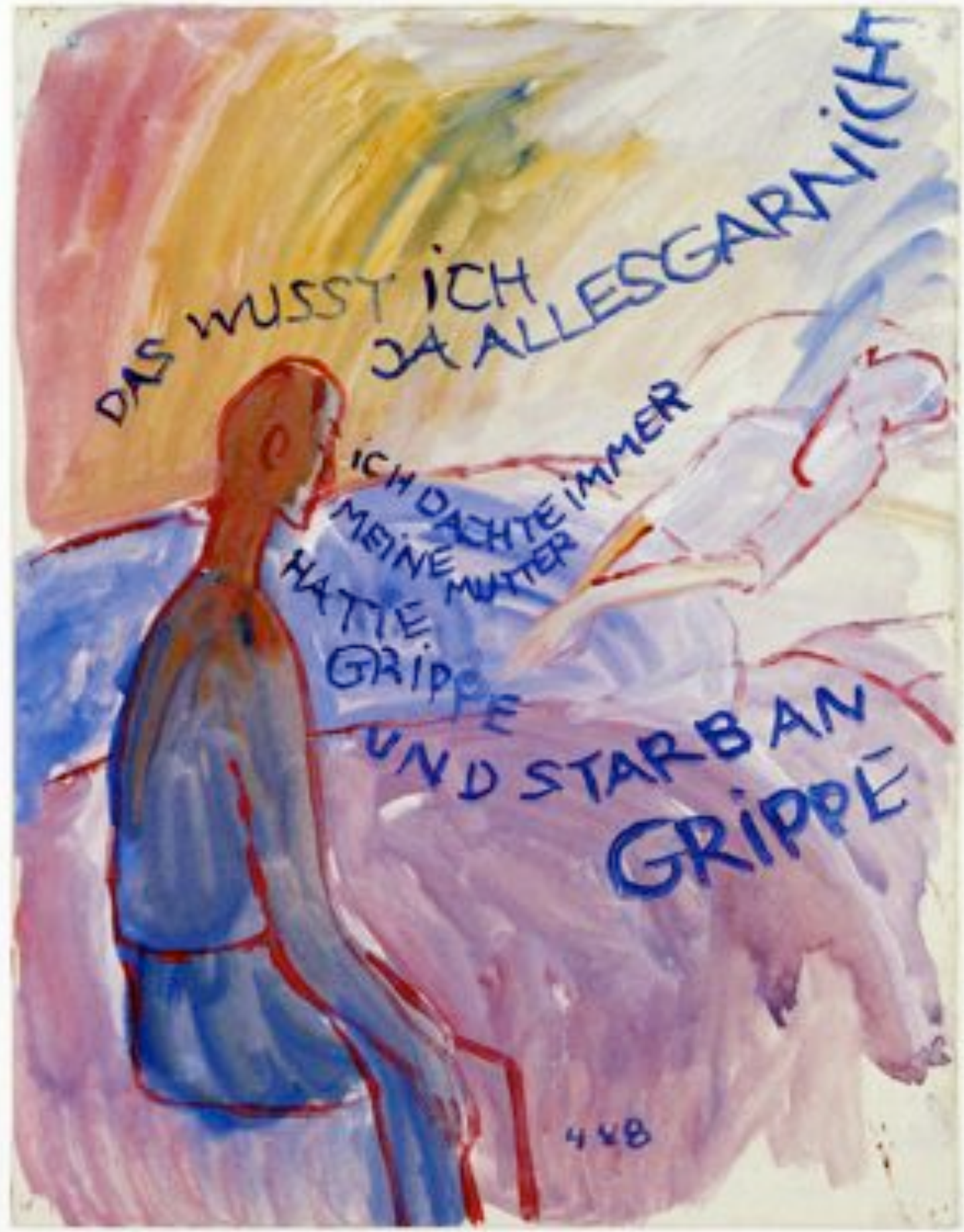

Figure 27

JHM: 4866 


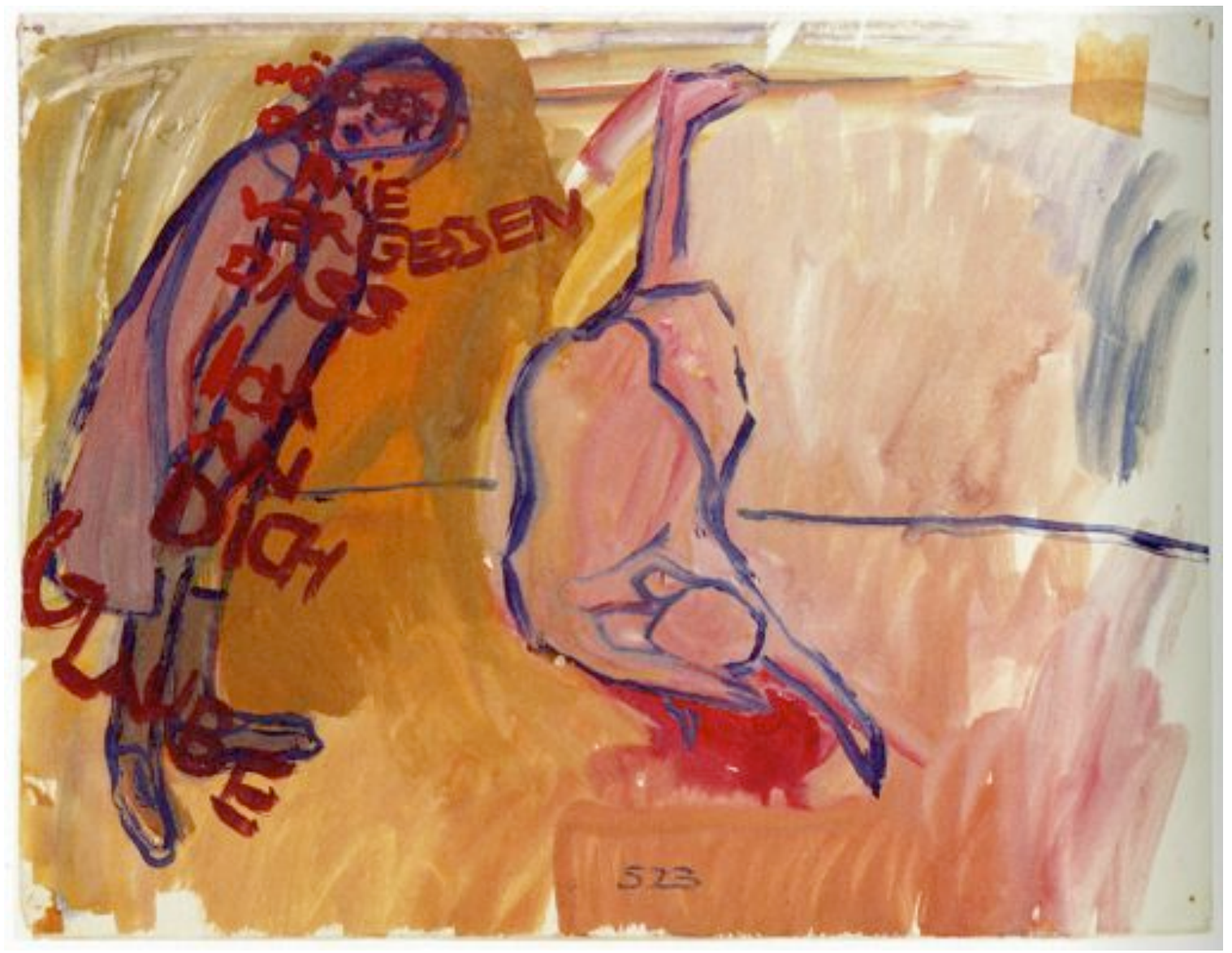

Figure 28

JHM: 4900v 


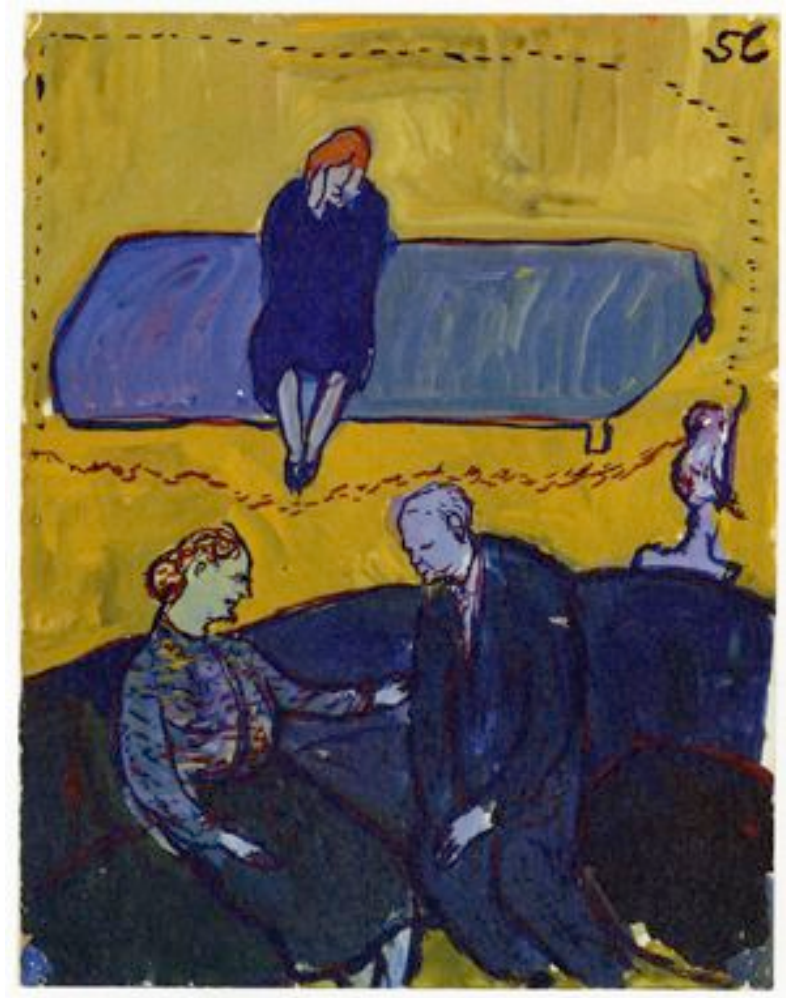

Figure 29

JHM: 4323

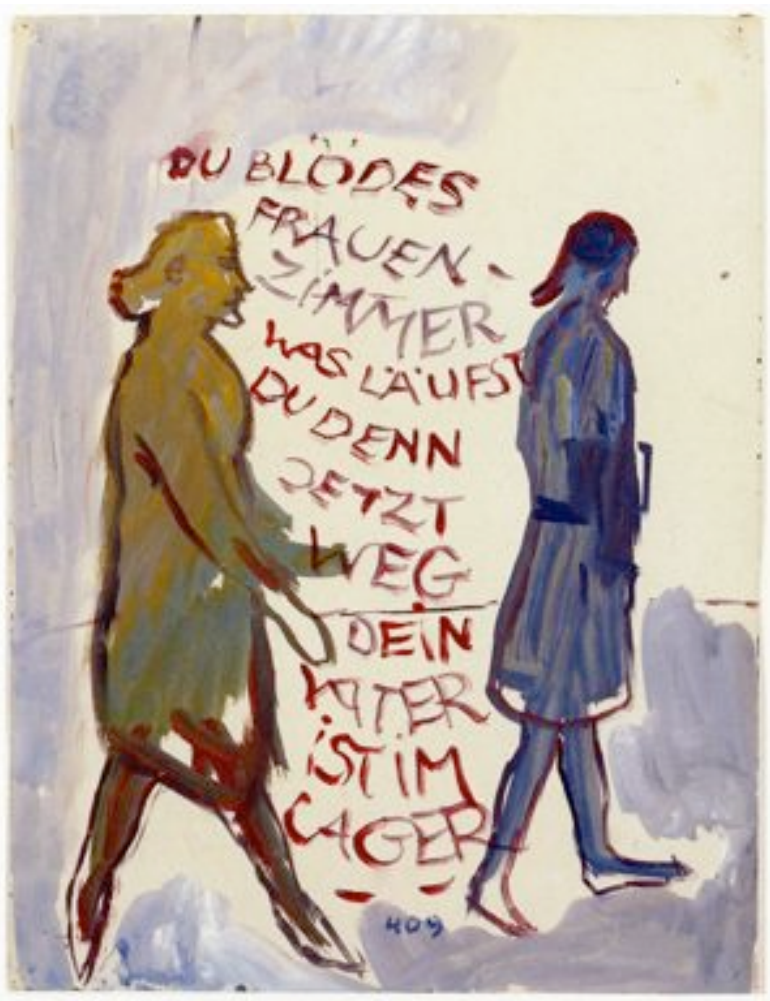

Figure 30

JHM: 4787 


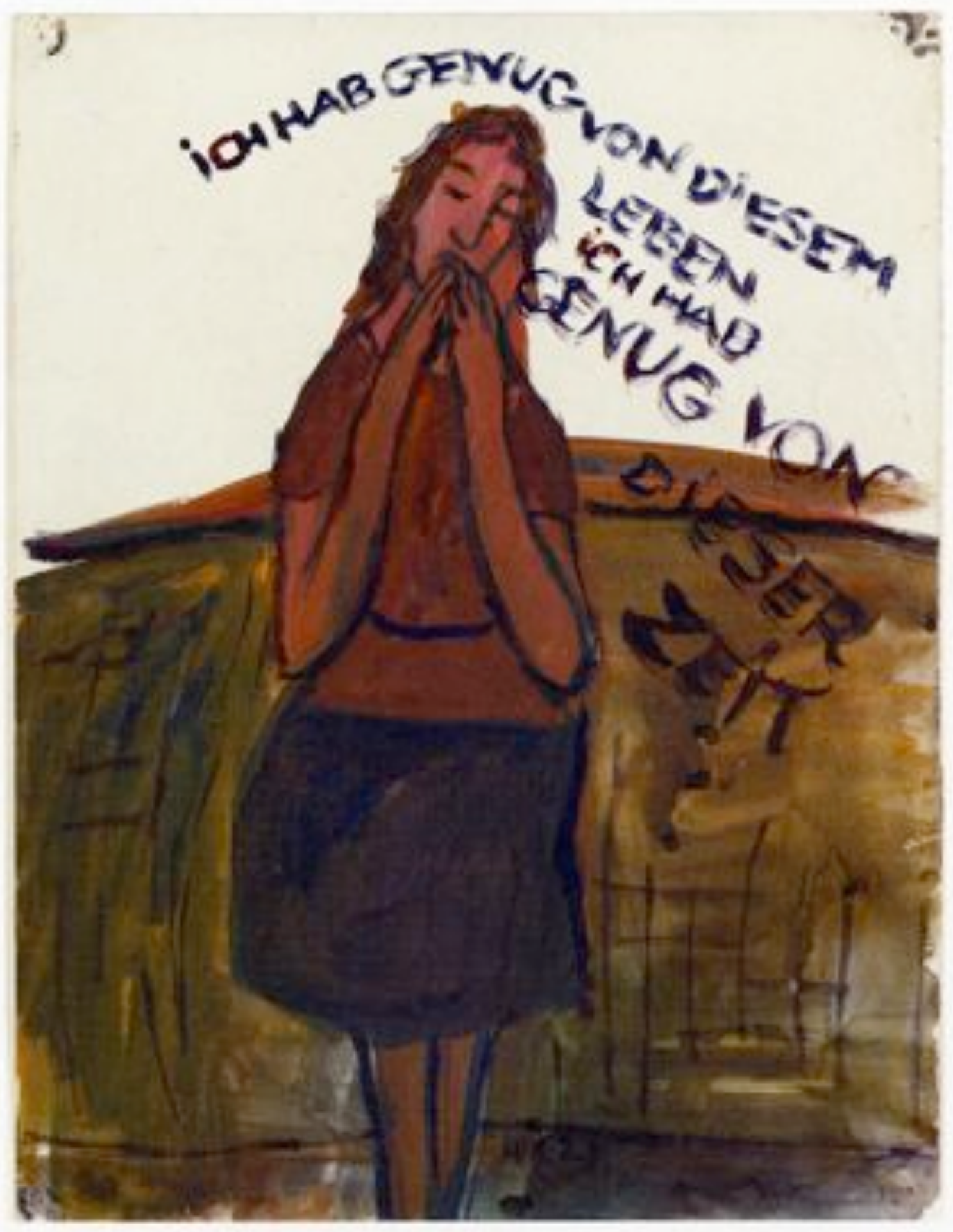

Figure 31

JHM: 4790 


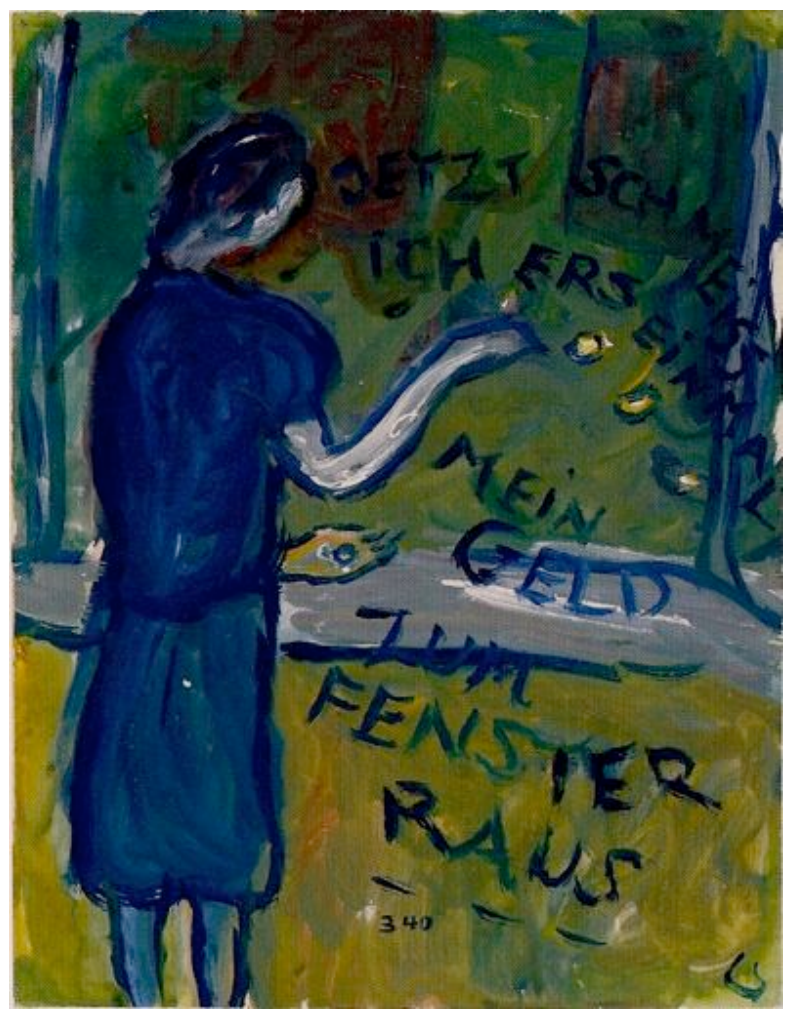

Figure 32

JHM: 4716

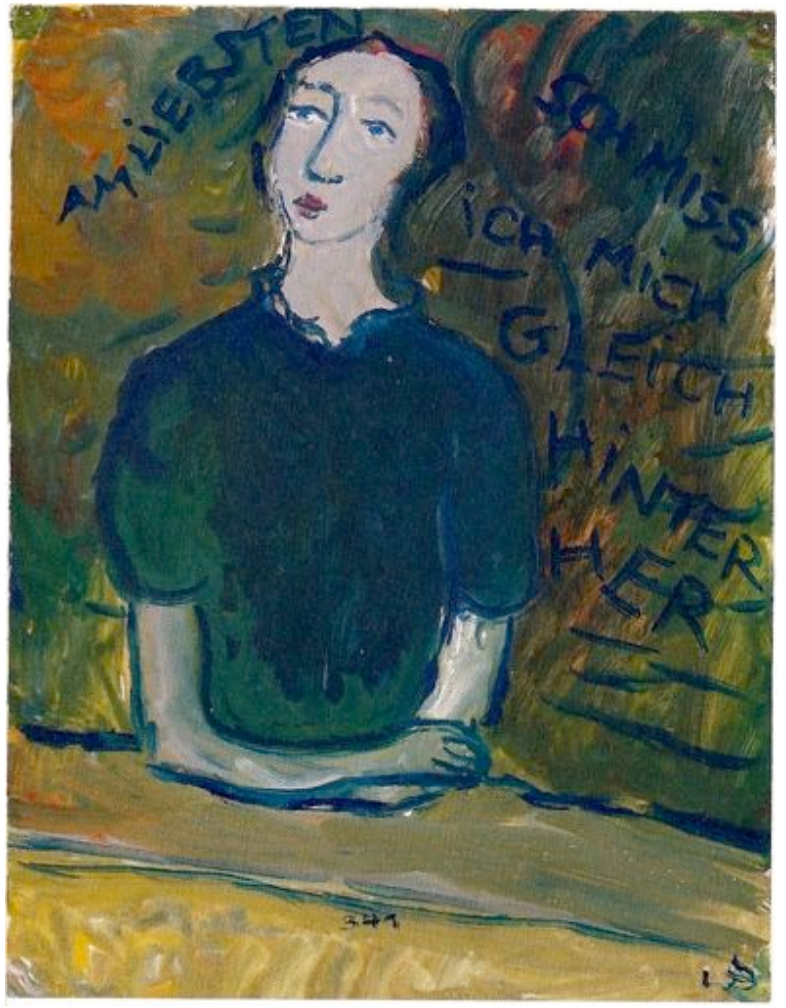

Figure 33

JHM: 4717 


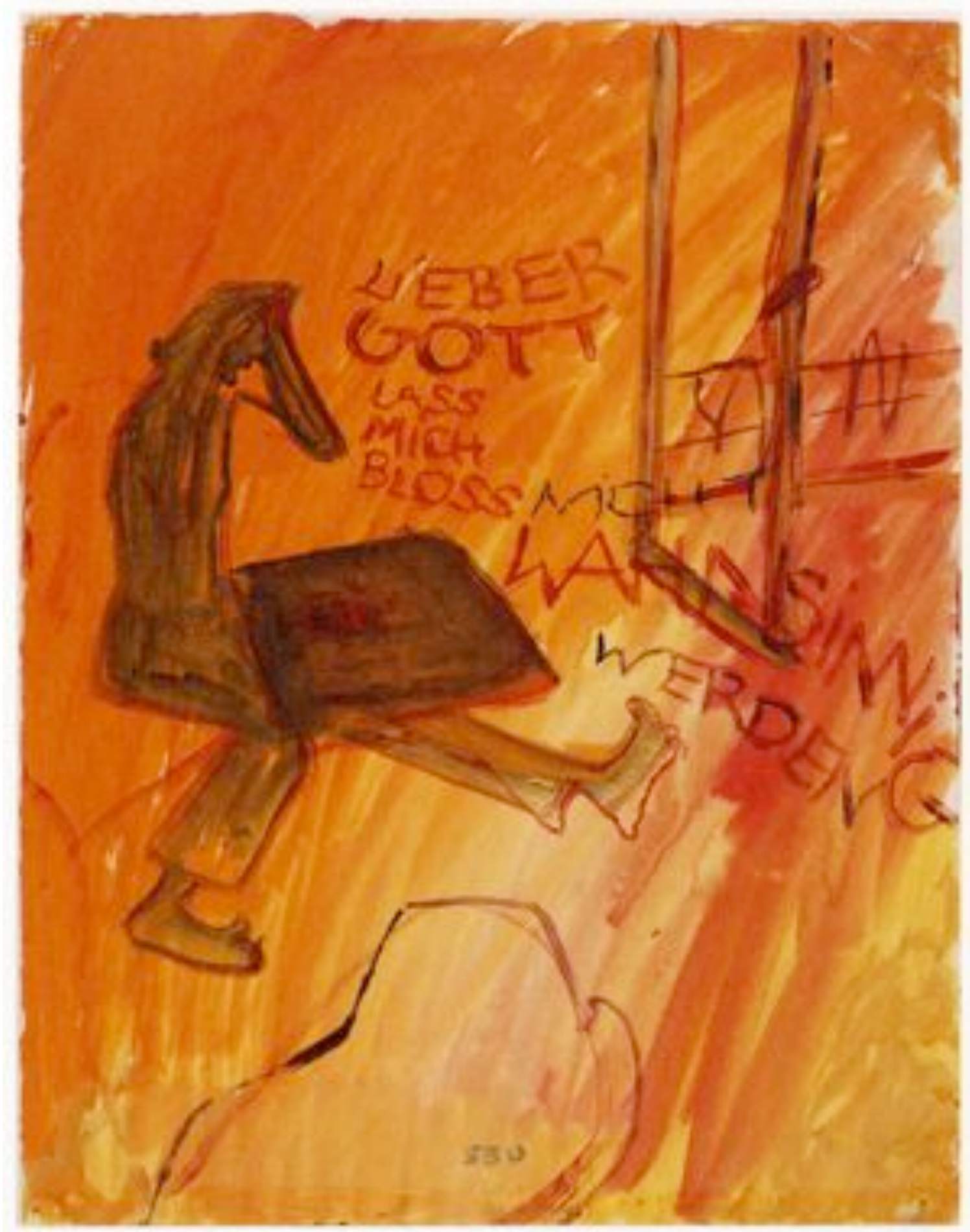

Figure 34

JHM: 4907 


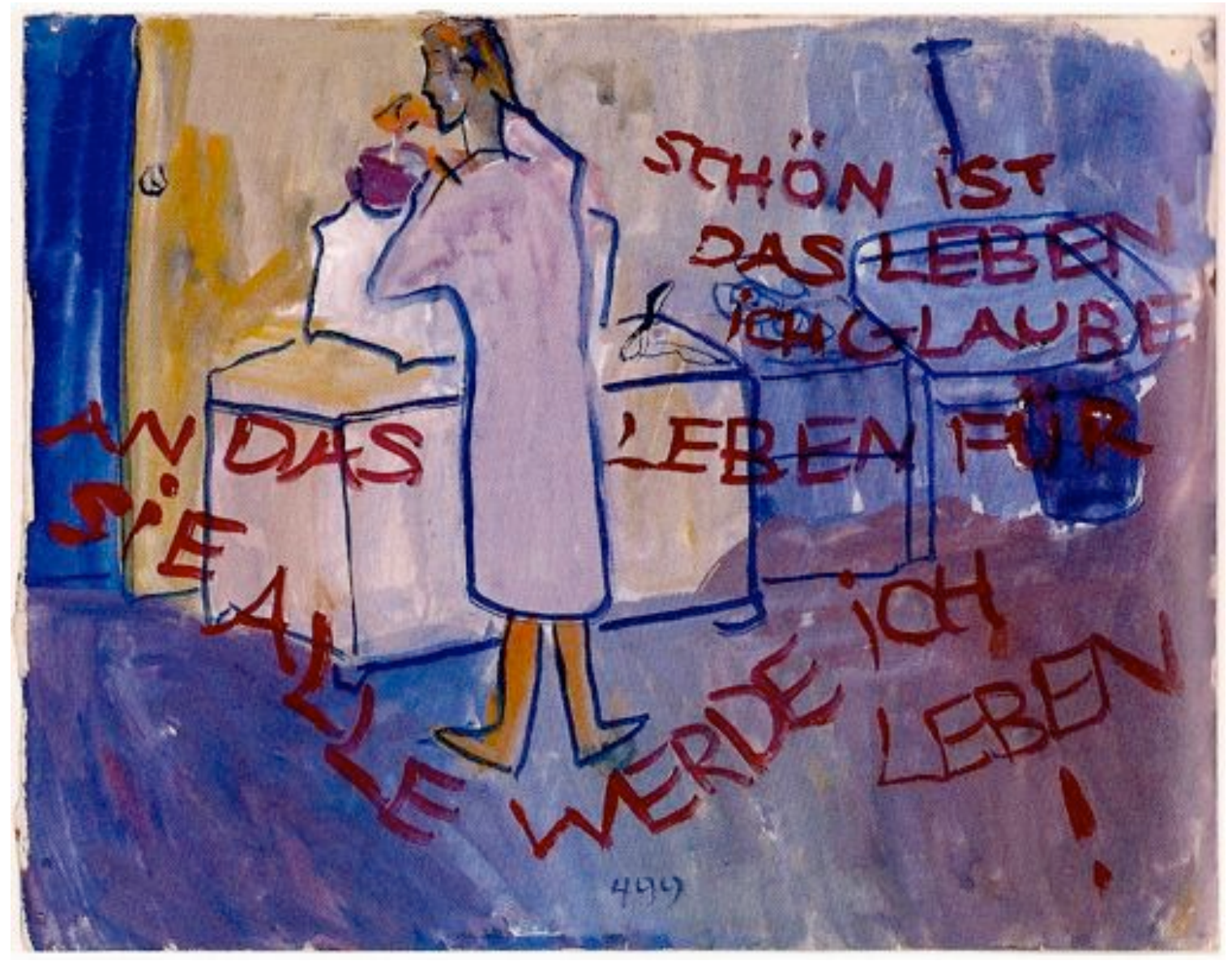

Figure 35

JHM: 4877 


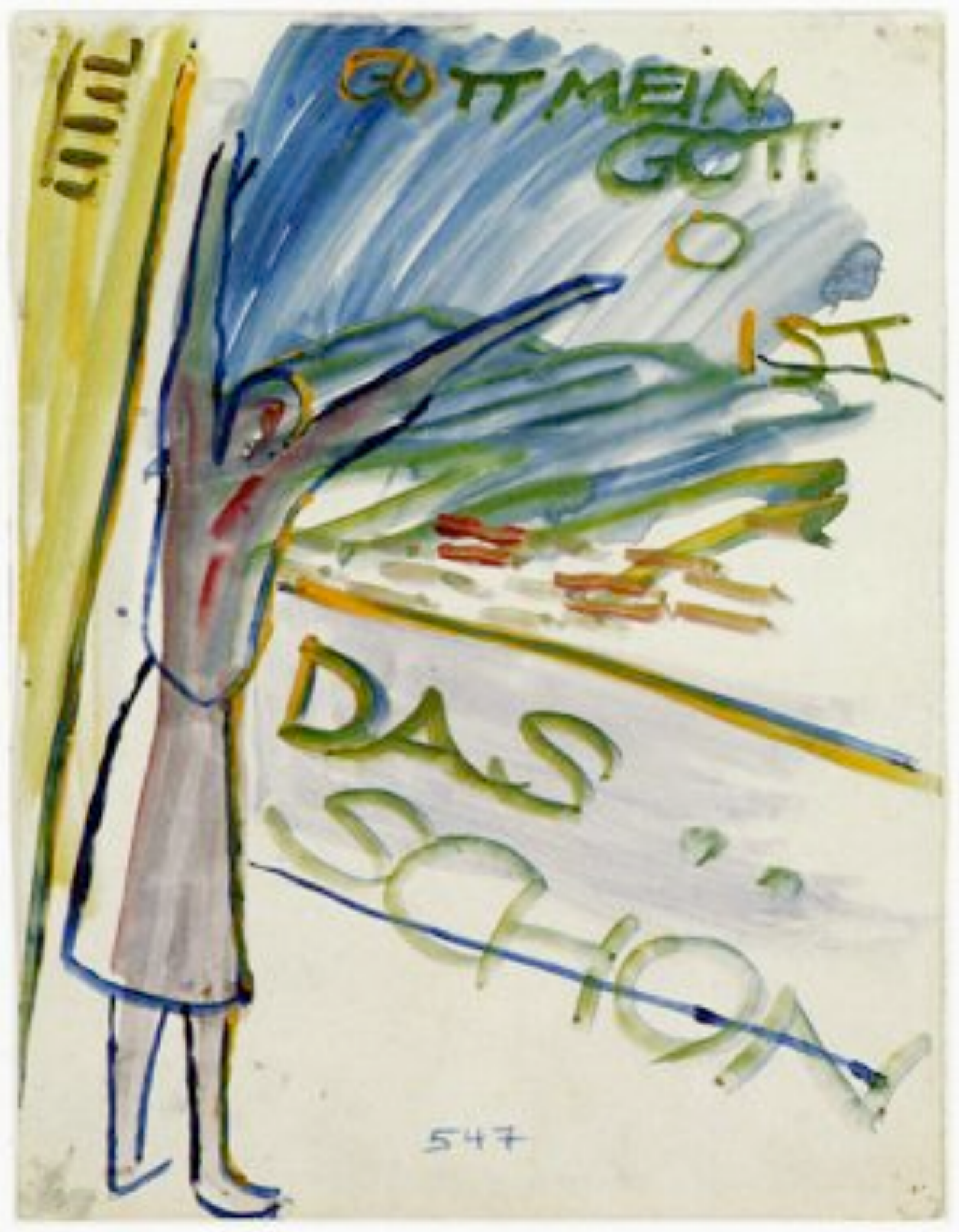

Figure 36

JHM: 4919v 


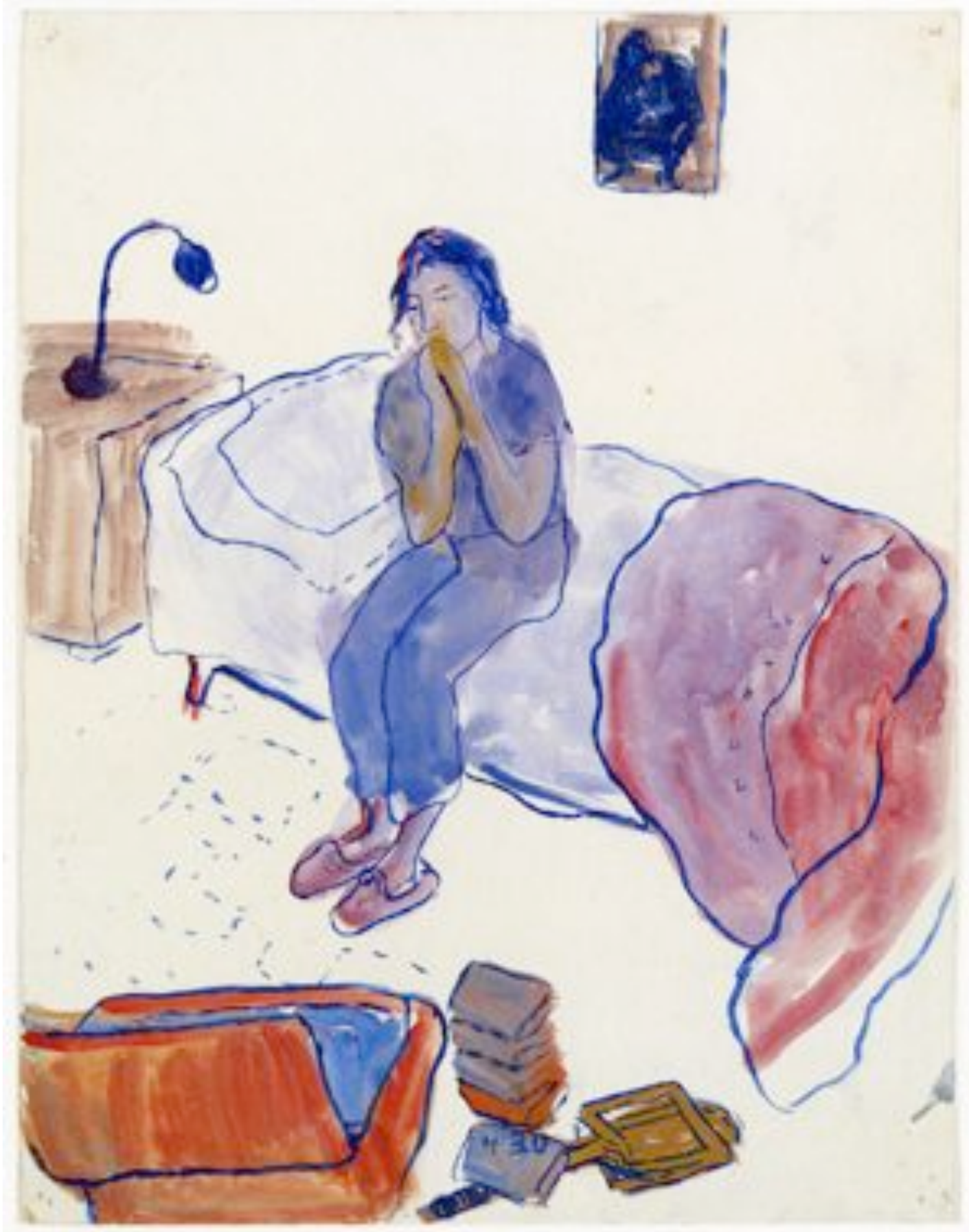

Figure 37

JHM: 4808 


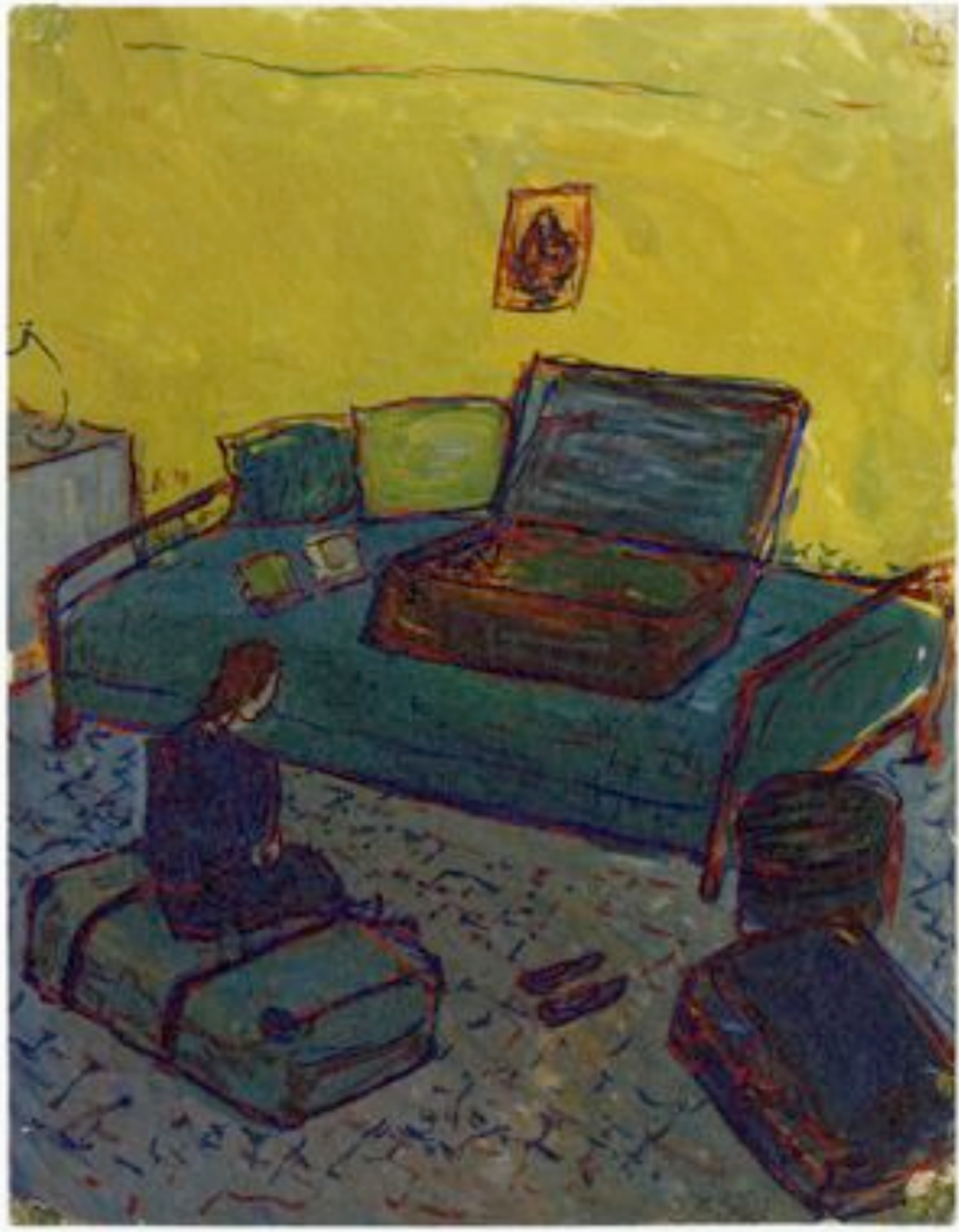

Figure 38

JHM: 4824 


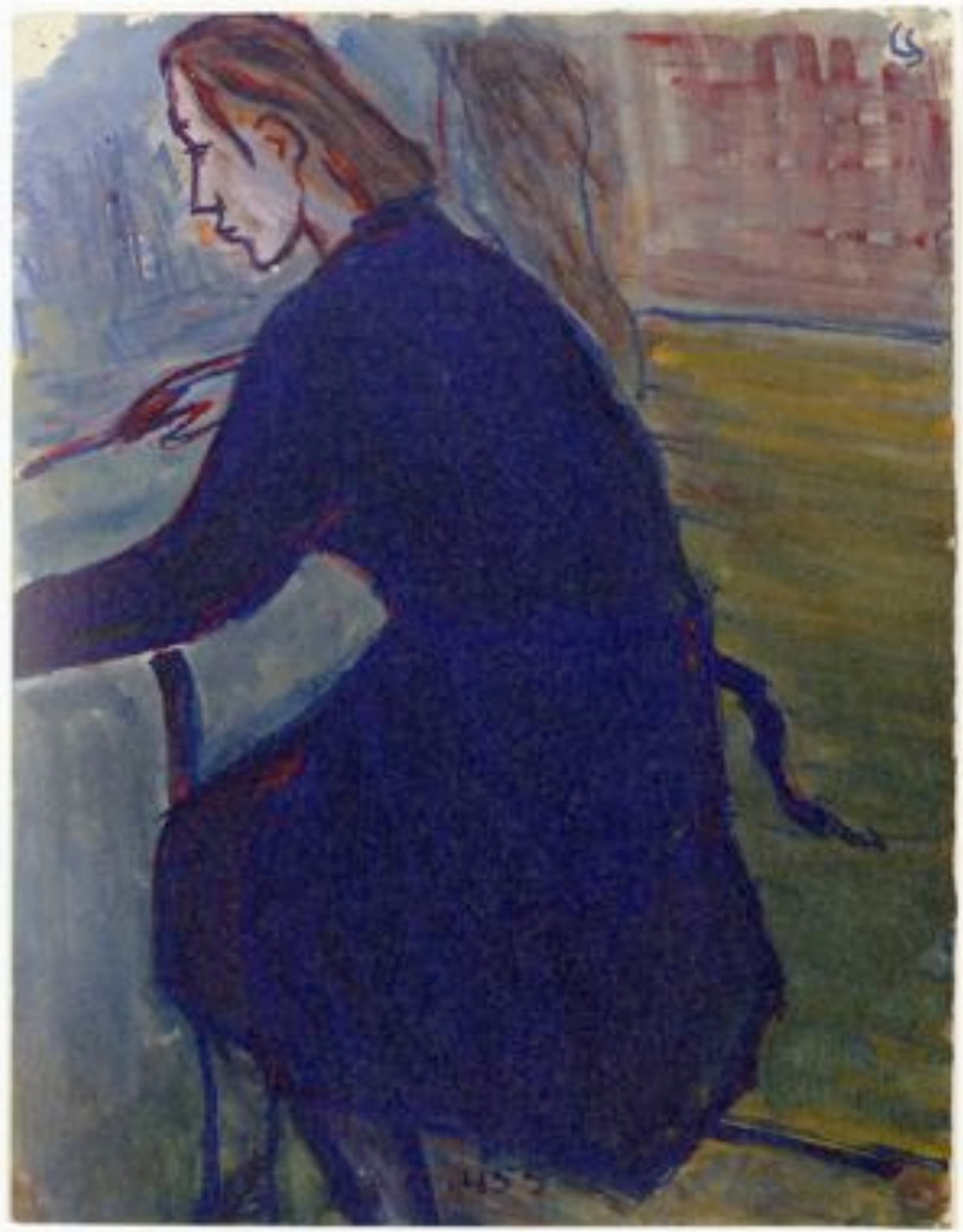

Figure 39

JHM: 4833 


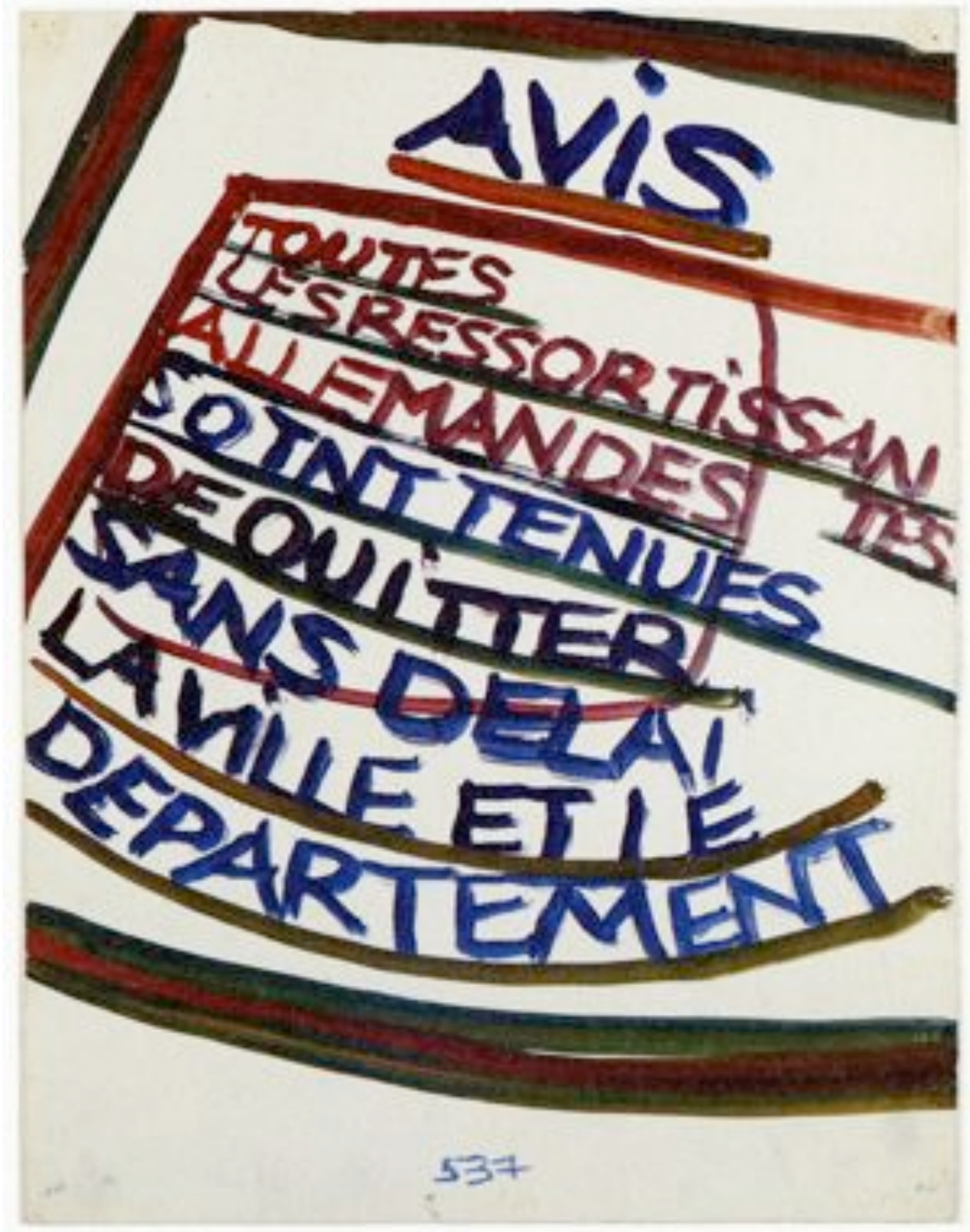

Figure 40

JHM: 4914 


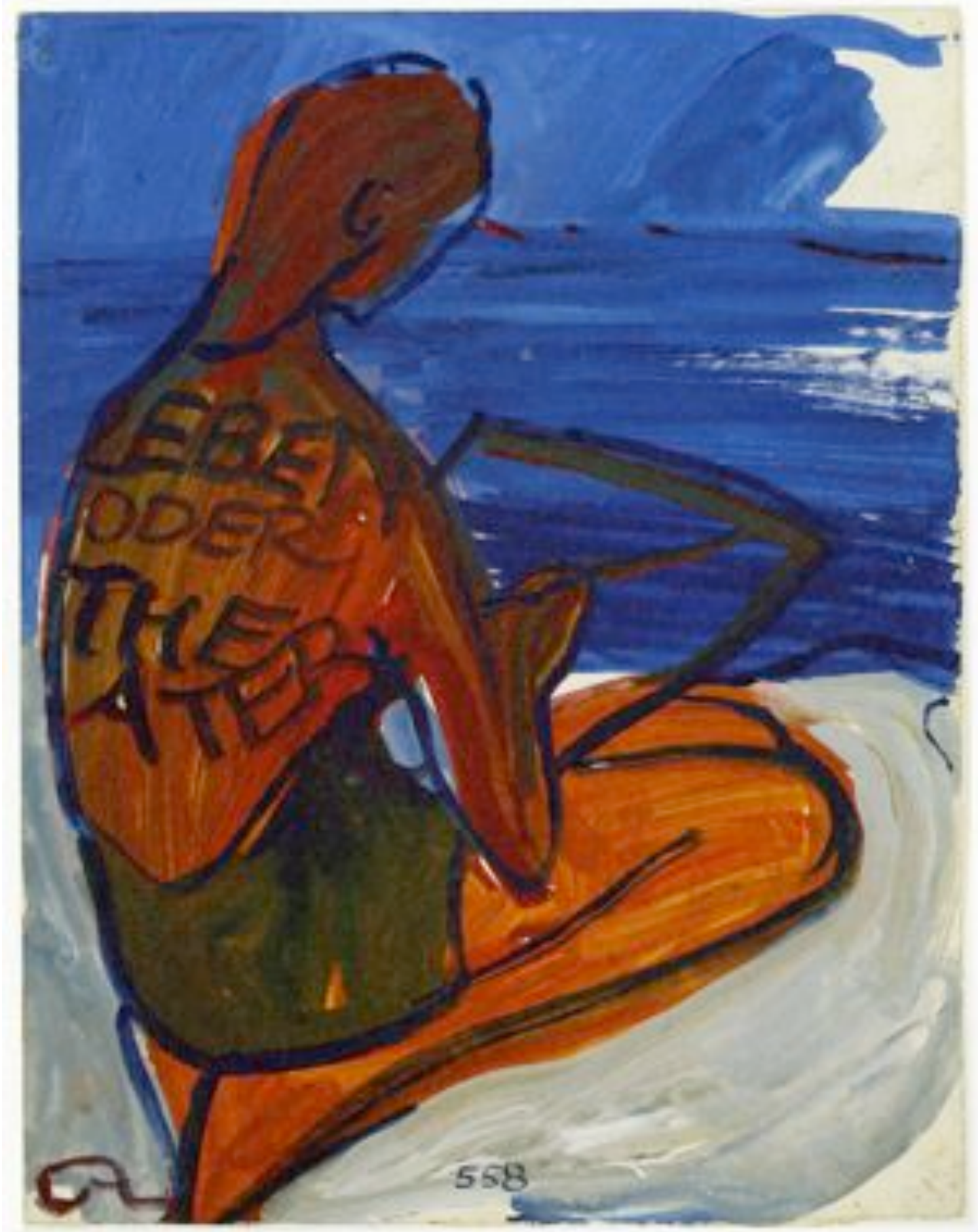

Figure 41

JHM: 4925 


\section{REFERENCES}

Adorno, Theodor. "Meditations on Metaphysics: I. After Auschwitz.” In Negative Dialectics, translated by E. B. Ashton, 361-365. New York: Continuum, 1973.

Andreasen, N.C. "Posttraumatic Stress Disorder." In Comprehensive Textbook of Psychiatry, $4^{\text {th }}$ ed., edited by H. I. Kaplan and B. J. Sadock, 918-24. Baltimore: Williams and Wilkins, 1985.

Austin, Carolyn F. "The Endurance of Ash: Melancholia and the Persistence of the Material in Charlotte Salomon's Leben? oder Theater?" Biography 31 no. 1 (Winter 2008): 103-132.

Barnett, Claudia. "Painting as Performance." The Drama Review 47, no. 1 (Spring 2003): 97-126.

Benjamin, Walter. “A Berlin Chronicle.” In One-Way Street, translated by Edmund Jephcott and Kingsley Shorter, 293-348. London: Verso Books, 1979.

Bohm-Duchen, Monica. "Life After Auschwitz.” In Reading Charlotte Salomon, 21-33.

Buerkle, Darcy. "Historical Effacements: Facing Charlotte Salomon.” In Reading Charlotte Salomon, 73-87.

Caruth, Cathy. Trauma: Explorations in Memory. Baltimore: Johns Hopkins University Press, 1995.

Contemporary Jewish Museum. "Charlotte Salomon: Life? or Theatre? 'Exhibition on view March 31, 2011-July 31, 2011."' Accessed March 27, 2011. http://www.thecjm.org/index.php?option=com_ccevents.

Felstiner, Mary Lowenthal. To Paint Her Life: Charlotte Salomon in the Nazi Era. New York: Harper Collins, 1994.

. "Taking Her Life-History: the Autobiography of Charlotte Salomon.” In Life Lines: Theorizing Women's Autobiography, by Bella Brodzki and Celeste Marguerite Schenck, 320-337. Ithaca: Cornell University Press, 1988.

. "Charlotte Salomon's Inward-turning Testimony." In Holocaust Remembrance: The Shapes of Memory, edited by Geoffrey H. Hartmann. Oxford: Blackwell, 1994. 
. "Create Her World Anew: Seven Dilemmas in Re-Presenting Charlotte Salomon." In Reading Charlotte Salomon, 194-211.

Fischer-Defoy, Christine and Paul Crossley. "Artists and Art Institutions in Germany 1933-1945.” Oxford Art Journal 9, no. 2 (1986): 16-29.

Greenberg, Reesa. "The Aesthetics of Trauma: Five Installations of Charlotte Salomon's Life? or Theatre?" In Reading Charlotte Salomon, 148-166.

Goldstein, Judith S. “Alone with Charlotte Salomon.” Partisan Review 69, no. 1 (Winter 2002): 75-77.

Herman, Judith Lewis. Trauma and Recovery. New York: Basic Books, 1992.

Herzberg, Judith. Charlotte: Life? or Theatre? An Autobiographical Play by Charlotte Salomon. New York: Viking Press, 1981.

Horowitz, Mardi. Stress Response Syndromes. Northvale, NJ: Jason Aronson, 1986.

Janet, Pierre. Psychological Healing. Translated by E. Paul and C. Paul. New York: Macmillan, 1925.

Kaplan, Marion A. "Jewish Women in Nazi Germany: Daily Life, Daily Struggles, 19331939.” Feminist Studies 16, no. 3 (Autumn 1990): 579-606.

Knafo, Danielle. In Her Own Image: Women's Self-Representation in Twentieth-Century Art. Madison, NJ: Fairleigh Dickinson University Press, 2009.

Lifton, Robert J. "The Concept of the Survivor." In Survivors, Victims, and Perpetrators: Essays on the Nazi Holocaust, edited by J. E. Dimsdale, 113-126. New York: Hemisphere, 1980.

Lixl-Purcell, Andreas, ed. Women of Exile: German Jewish Autobiographies Since 1933. New York: Greenwood, 1988.

McNally, Richard J. Remembering Trauma. Cambridge: Harvard University Press, 2003.

Oberlaender, Franklin A. "My God, They Just Have Other Interests." The Oral History Review 24, no. 1 (Summer 1997): 23-53.

Partsch, Susanna. "Charlotte Salomon: Anmerkungen zu einem Zyklus.” Kritische Berichte 10, no. 4 (1982), 49-56. 
Pollock, Griselda. "Theater of Memory: Trauma and Cure in Charlotte Salomon's Modernist Fairytale.” In Reading Charlotte Salomon, 35-72.

. "What Does a Woman Want?: Art Investigating Death in Charlotte Salomon's Leben? oder Theater?" Art History 30, no. 3 (June 2007): 383-405.

.Encounters in the Virtual Feminist Museum: Time, Space and the Archive. London: Routledge, 2007.

. "Life-Mapping: Or, Walter Benjamin and Charlotte Salomon Never Met." In Conceptual Odysseys: Passages to Cultural Analysis, edited by Griselda Pollock, 63-88. New York: I. B. Tauris \& Co. Ltd., 2007.

. "Mapping the 'bio' in Two Graphic Systems with Gender in Mind: Reading Van Gogh through Charlotte Salomon and Vice Versa." In Biographies and Space: Placing the Subject in Art and Architecture by Dana Arnold and Joanna R. Sofaer, 115-139. New York: Routledge, 2008.

Rubenstein, Raphael. "Charlotte Salomon: A Visual Testament." Art in America 87, no. 1 (January 1999): 77-83, 114.

Paul Russell, "Trauma, Repetition and Affect." Paper presented at Psychiatry Grand Rounds, Cambridge Hospital, Cambridge, Massachusetts, September 5, 1990.

Salomon, Charlotte, and Judith CE Belinfante. Charlotte Salomon: Life? or Theatre? Zwolle, Netherlands: Waanders, 1998.

Scaer, Richard. The Trauma Spectrum: Hidden Wounds and Human Resiliency. New York: Norton, 2005.

Scarry, Elaine. The Body in Pain: The Making and Unmaking of the World. New York: Oxford University Press, 1985.

Schmetterling, Astrid. "Inscriptions of Difference in Charlotte Salomon's Work." In Reading Charlotte Salomon, 140-147.

Schultz, Deborah, and Edward Timms. "Charlotte Salomon: Images, Dialogues and Silences.” Word \& Image 24, no. 3 (July-September 2008): 269-281.

Siverman, Lisa. "Reconsidering the Margins: Jewishness as an Analytical Framework." Journal of Modern Jewish Studies 8, no. 1 (March 2009): 103-120.

Steinberg, Michael P., and Monica Bohm-Duchen, eds. Reading Charlotte Salomon. Ithaca: Cornell University Press, 2006. 
Steinberg, Michael P. “Reading Charlotte Salomon: History, Memory, Modernism.” In Reading Charlotte Salomon, 1-20.

Stiles, Kristine. "Shaved Heads and Marked Bodies: Representations from Cultures of Trauma," in Talking Gender: Public Images, Personal Journeys, and Political Critiques, edited by Nancy A. Hewitt, Jean F. O'Barr, and Nancy Rosenbaugh, 36-64. Chapel Hill: University of North Carolina Press, 1996.

Timms, Edward, and Deborah Schultz. "Charlotte Salomon's Life? or Theatre?: A Multimedia Response to the Crisis of German Culture." Word \& Image 24, no. 3 (July-September 2008): 251-268.

Van Alphen, Ernst. Caught by History: Holocaust Effects in Contemporary Art, Literature, and Theory. Stanford, CA: Stanford University Press, 1997.

. "Giving Voice: Charlotte Salomon and Charlotte Delbo." In Reading Charlotte Salomon, 114-125.

Van der Kolk, Bessel A., Alexander C. McFarlane, and Lars Weisaeth. Traumatic Stress: The Effects of Overwhelming Experience on Mind, Body, and Society. New York: Guilford Press, 1996.

Van der Kolk, Bessel, and Onno van der Hart, "The Intrusive Past: The Flexibility of Memory and the Engraving of Trauma." In Trauma: Explorations in Memory, 158-182.

Warshaw, Robin, and Mary P. Koss. I Never Called it Rape. New York: Harper \& Row, 1988.

White, Leah. "Autobiography, Visual Representations, and the Preservation of Self." Mosaic: A Journal for the Interdisciplinary Study of Literature 37, no. 2 (2004): 107. Accessed January 12, 2011. http://search.proquest.com/docview/205344913?accountid=14665.

. "Autobiography as Performative Identity Construction: The Fragmented Subjectivities of Charlotte Salomon." Text and Performance Quarterly 21, no. 2 (2001): 77-94.

. "Life? or Theatre?: A Text of Incongruity and Fragmented Subjectivity." PhD diss., Arizona State University, 1997. 


\section{CURRICULUM VITAE}

NAME: $\quad$ Brooke Leeton

ADDRESS: 2012 Village Dr.

Apt. \#3

Louisville, KY 40205

EMAIL: $\quad$ brookeleeton@gmail.com

EDUCATION: B.S., Communications

University of Tennessee, 1997-2002

AWARDS: $\quad$ Cressman Scholar, 2010-11, Teaching Assistant for Dr. Susan Jarosi Cressman Scholar, 2009-10, Student Worker, Visual Resources Center

AFFILIATIONS: Vice President, Aegis, Fine Arts Graduate Organization, 2009-10 College Art Association, 2010-11 